UNIVERSIDADE DE SÃO PAULO

FACULDADE DE FILOSOFIA, LETRAS E CIÊNCIAS HUMANAS DEPARTAMENTO DE LETRAS CLÁSSICAS E VERNÁCULAS ÁREA DE FILOLOGIA E LÍNGUA PORTUGUESA

Maria de Lurdes Zanoli

\title{
A CHECAGEM DE 'FOCO' DA CATEGORIA 'SUJEITO' NO CABO-VERDIANO - VARIEDADE DE SÃO NICOLAU
}

Versão corrigida

São Paulo

2014 


\section{UNIVERSIDADE DE SÃO PAULO - USP \\ Faculdade de Filosofia Letras e Ciências Humanas - FFLCH \\ Departamento de Letras Clássicas e Vernáculas - DLCV}

Maria de Lurdes Zanoli

Dissertação apresentada ao

Programa de Pós- Graduação do Departamento de Letras Clássicas e Vernáculas da Faculdade de Filosofia, Letras e Ciências Humanas da Universidade de São Paulo, como requisito para a obtenção do título de Mestre em Filologia e Língua Portuguesa.

Versão Corrigida

De acordo

Orientadora: Profa. Dra. Márcia Santos Duarte de Oliveira

São Paulo

2014 
BANCA EXAMINADORA

Membros Titulares:

Orientadora: Profa. Dra. Márcia Santos Duarte de Oliveira (DLCV / USP)

Profa. Dra. Beatriz Protti Christino (Universidade Federal de Rio de Janeiro)

Profa. Dra. Flaviane R. Fernandes-Svartman (Universidade de São Paulo) 


\section{Dedicatória}

$\grave{A}$

Hermínio Zanoli (in memoriam) que me ensinou a ser forte e a persistir diante dos obstáculos que a vida oferece.

Palmira Gavioli Zanoli que esteve ao meu lado em todos os momentos, me dando apoio e incentivando sempre. 


\section{Agradecimentos}

Primeiramente agradeço a Deus pela força, pela coragem e por todas as bençãos concedidas na minha vida, e em especial, por ter me guiado com fé e humildade por esse processo.

Agradeço à minha família, em especial à minha mãe, que nunca me desistimulou, ao contrário, sempre esteve ao meu lado, me ajudo de todas as maneiras possíveis.

Agradeço em especial, à minha orientadora $\operatorname{Prof}^{a} \operatorname{Dr}^{\mathrm{a}}$ Márcia Santos Duarte de Oliveira que me guiou com sabedoria e paciência através desta longa jornada. Muito mais que uma orientadora, tornou-se uma amiga muito especial, que em recebeu em sua casa, com muito carinho, e em dedicou grande parte de seus dias durante esse período. Agradeço a ela por sempre exigir o melhor de mim, e por nunca ter deixado de acreditar em mim. A ela, meu muito obrigada, de todo meu coração.

Agradeço ainda à grande ajuda de Flaviane R. Fernandes-Svartman, que foi de extrema importância para essa dissertação, pois, sem sua ajuda, a parte fonologica desse trabalho não seria a mesma. À professora Flaviane, meus sinceros agradecimentos!

Agradeço também, à professora Dra. Beatriz Protti Christino, por suas preciosas considerações na banca de qualificação, que muito contribuiram para a relaização dessse trabalho.

Agradeço à instituição USP por todas as oportunidades de aprendizagem.

Agradeço de todo o meu coração, meu amigo cabo-verdiano Francisco João Lopes pela preciosa colaboração e por todos os dados fornecidos, que foram de grande valia para esse estudo.

Agradeço minha querida amiga Ana Carolina Neves, que mesmo à distância, esteve sempre presente com sua maravilhosa amizade!

Agradeço ainda aos colegas do GELIC por todo apoio: Eduardo Santos, Raquel Silva e Ednalvo Campos.

Por fim, agradeço aos professores que contribuiram para minha formação nesse mestrado: Márcia Santos Duarte de Oliveira, Flaviane R. Fernandes-Svartman e Maria Clara Paixão de Souza. 


\section{SUMÁRIO}

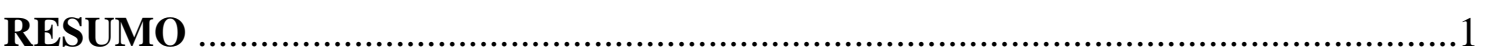

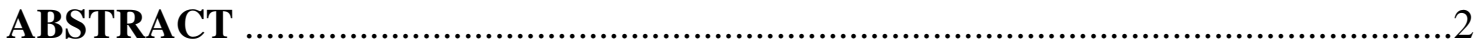

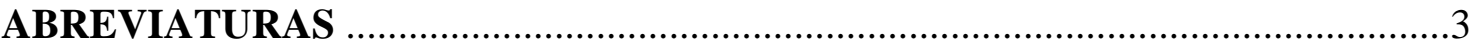

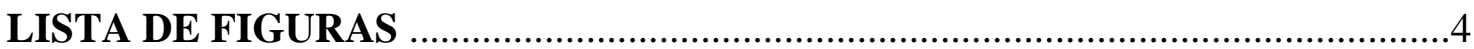

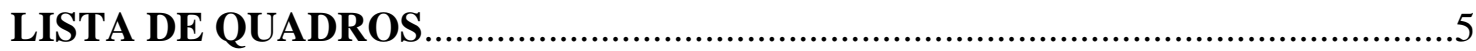

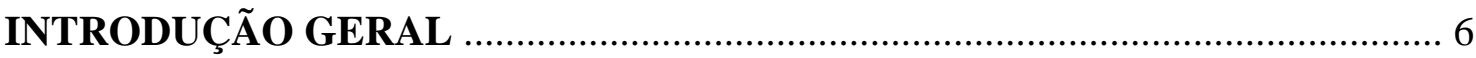

CAPÍtulo 1 - O ARQUIPÉlago de CABO VERDE E A ILHA DE SÃo NICOLAU

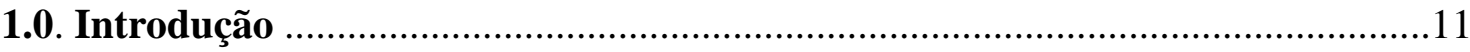

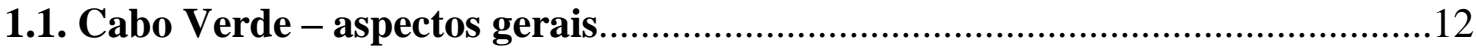

1.1.1. A chegada dos portugueses nas ilhas de Cabo Verde............................... 15

1.1.2. A diáspora cabo-verdiana.......................................................................21

1.1.3. Dados demográficos de Cabo Verde .....................................................24

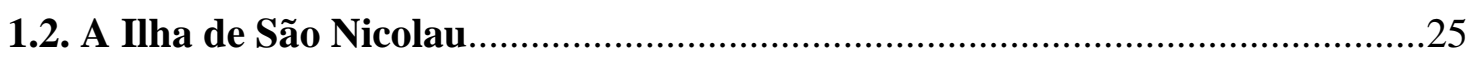

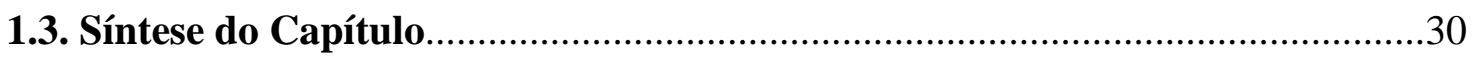

CAPÍTULO 2 - O CABO-VERDIANO E A VARIEDADE DE SÃO NICOLAU -

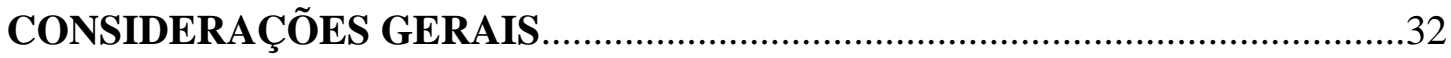

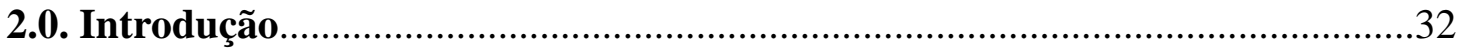

2.1. O Crioulo de modo geral e o cabo-verdiano.........................................................34

2.1.1. Hipóteses sobre a gêneses das línguas crioulas - algumas teorias..........34

2.1.2. Os conceitos de pidgin, crioulo e pidgincrioulo.......................................38

2.2. Um panorama sociolinguístico de Cabo Verde ...............................................42

2.3. A língua cabo-verdiana com ênfase na variedade de Barlavento....................46

2.3.1. Um enfoque no cabo-verdiano enquanto sistema linguístico....................47

2.3.1.1. Aspectos da morfossintaxe nominal: o 'gênero' ........................49

2.3.1.2. Aspectos da morfossintaxe nominal: o 'número' '........................52

2.3.1.3. A Marcação do Tempo, Aspecto e Modo em cabo-verdiano

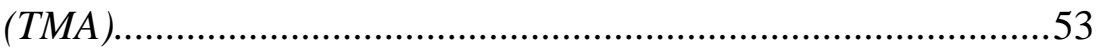

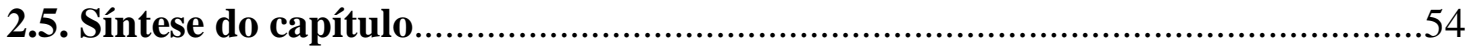

CAPÍTULO 3- REFERENCIAL TEÓRICO-METODOLÓGICO.........................58

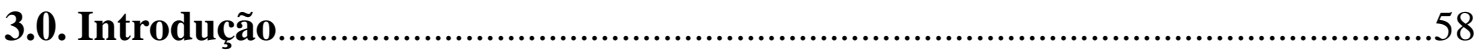

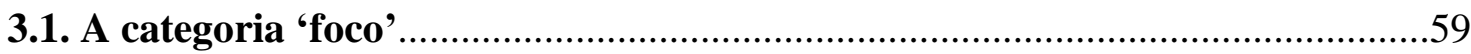


3.2. Referencial teórico do 'foco' .63

3.2.1. Considerações sobre a checagem do 'foco' em PB e PE .63

3.2.2. Considerações sobre a checagem do 'foco' em São Nicolau. .65

3.2.3. Teoria fonológica ............................................................................67

3.2.3.1. Fonologia entoacional..........................................................67

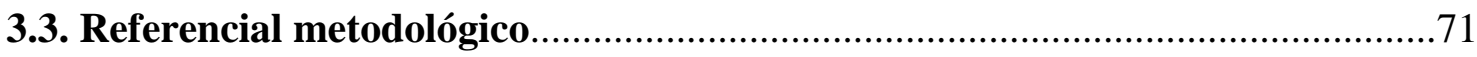

3.3.1. Corpus e metodologia ........................................................................... 71

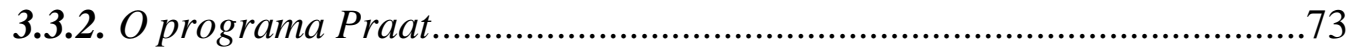

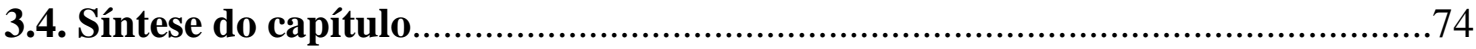

CAPÍTULO 4 - PARA UM ALARGAMENTO DA ANÁlISE DA CHECAGEM DE 'FOCO' DA CATEGORIA 'SUJEITO' NO CABO-VERDIANO DE SÃO

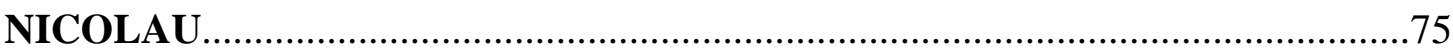

4.0. Introdução

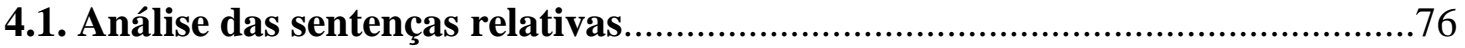

4.1.1. Sentenças que contêm relativas: sem marcação de foco..........................76

4.2. Análise das sentenças clivadas e a checagem de foco da categoria 'sujeito'.....83 4.2.1. A tipologia do 'foco’ em São Nicolau.......................................................84

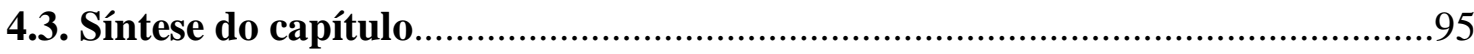

5 - CONCLUSÃO

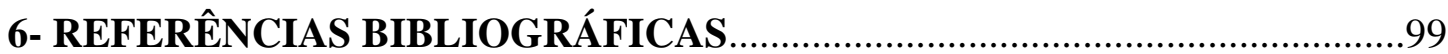

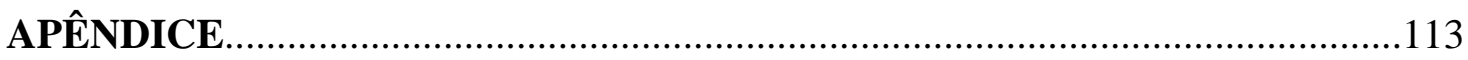




\section{RESUMO}

Nessa dissertação, o objetivo principal é a análise da checagem de 'foco' da categoria 'sujeito' no cabo-verdiano, variedade de São Nicolau, região de Barlavento. No tocante à introdução dos aspectos sociolinguísticos do cabo-verdiano de São Nicolau, o trabalho corrobora que a morfossintaxe nominal e verbal da língua atesta marcas de flexão, como por exemplo, o 'gênero', o 'número' e marca de flexão verbal. $\mathrm{O}$ resultado do estudo, a partir do alargamento do corpus, submetido à ferramenta Praat, ratifica a análise realizada por Lopes \& Zanoli (2012): o foco da categoria 'sujeito' nessa variedade de Barlavento só pode ser realizado por meio de estruturas clivadas. No entanto, a análise amplia o escopo do estudo anterior: aponta três tipos de clivadas que marcam a tipologia do 'foco' em São Nicolau e identifica, por meio da análise entoacional, a predominância de um acento bitonal específico do foco na língua: L+H*

Palavras-chaves: checagem de 'foco'; categoria 'sujeito'; cabo-verdiano de São Nicolau; clivagem; interface sintaxe/fonologia. 


\begin{abstract}
In this dissertation, the main goal is the analysis of the checks 'focus' category 'subject' in Cape Verde, variety of St. Nicholas, the Windward area.

Regarding the introduction of the sociolinguistic aspects of Cape Verde of St. Nicholas, the work confirms that the nominal and verbal morphosyntax of the language attests brands flexion, for example, the 'gender', the 'number' and verbal inflection. The result of the study, from the extension of the corpora underwent Praat tool, confirms the analysis by Lopes \& Zanoli (2012): the focus of the category 'subject' in this variety Windward can only be accomplished through cleaved structures. However, the analysis expands the scope of the previous study: Three types of cleaved marking the typology of 'focus' on St. Nicholas and identifies, by means of analysis intonation, the predominance of a bitonal accent specific focus on language: $\mathrm{L}+\mathrm{H}^{*}$.
\end{abstract}

Keywords: checking 'focus'; category 'subject'; Cape Verde São Nicolau; cleavage; interface syntax / phonology. 


\section{ABREVIATURAS E SÍMBOLOS}

A- Afrikaans

COP - Cópula

$\mathrm{CP}$ - Sintagma Complementizador

$\mathrm{C}^{\circ} / \mathrm{C}_{0}-$ Núcleo do Sintagma

DOC.- Documento

DP - Sintagma Determinante

ECNP- Espanhol Caribenho Não Padrão

FRELIMO- Frente de Libertação de Moçambique

Fin - Finitude

FinP - Sintagma Finitude

$\mathrm{F}^{\mathbf{o}}$ - Núcleo do Sintagma Foco

Foc - Foco

FocP -Sintagma Foco

ForceP - Sintagma Force

HAT - Habitual - se refere à partícula TMA

IP- inflection frase (sintagma flexional)

LAs- Línguas do oeste africano

MLSTP- Movimento de Libertação de São Tomé e Príncipe

MPLA- Movimento de Libertação de Angola

NEG - Negação

NP- sintagma nominal

NURC - Norma Urbana Culta

OBJ- objeto

ONU- Organização das Nações Unidas

OP- Operador

PAIGC- Partido Africano da Independência da Guiné e de Cabo Verde

PE- Português europeu

Perfect-perfectivo

PB- Português brasileiro

PVB- Português Vernacular Brasileiro

SCL- small clause (pequena oração)

Spec-Especificador

SVO- Ordem sujeito-verbo-objeto

TAM - Tempo, aspecto e modo

UNITA - União Nacional para Independência Total de Angola

VS- Ordem verbo-objeto
(*) Sentença agramatical

(\#) Sentença pragmaticamente anômala 


\section{LISTA DE FIGURAS}

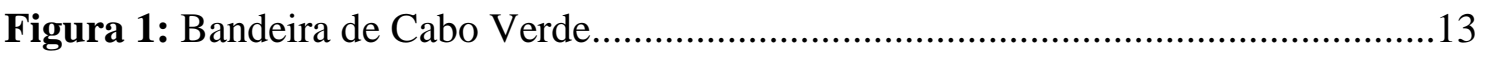

Figura 2: Cabo Verde: Ilhas de Barlavento e Sotavento.............................................13

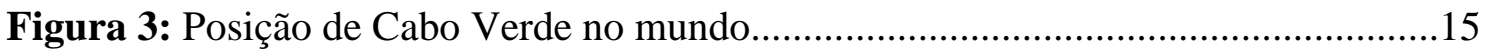

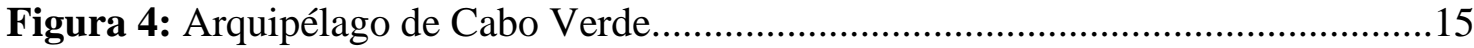

Figura 5: Ribeira Grande de Santiago, sede da Capitania Sul doada a António di Noli a primeira rua denominada Rua da Banana.............................................................17

Figura 6: Ilha de São Vicente - vista da entrada do Porto Grande...............................22

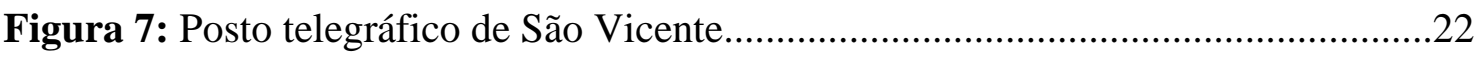

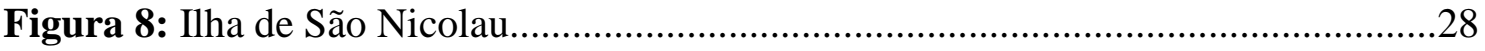

Figura 9: Vista de um povoado da Ribeira - São Nicolau...........................................29

Figura 10: Seminário-Liceu de São Nicolau..............................................................

Figura 11: Encontro de ex-seminaristas do Liceu........................................................ 31

Figura 12: Trecho da carta trocada entre Schuchardt e Coelho a respeito de dialetos crioulos do português existentes na África e Ásia......................................

Figura 13: Situação linguística em Cabo Verde......................................................50

Figura 14: Epicentros das duas principais variedades do cabo-verdiano: Santiago em

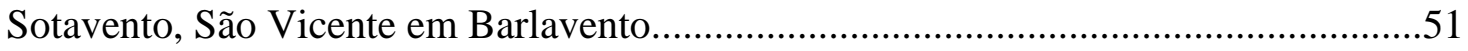

Figura 15: Imagem Praat de uma Construção Relativa..............................................86

Figura 16: Imagem Praat de uma sentença neutra ou básica....................................87

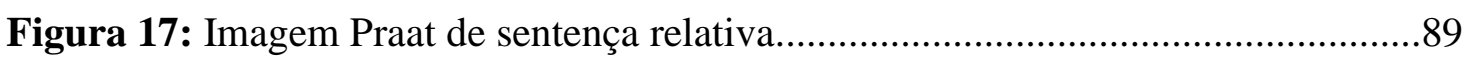

Figura 18: Imagem Praat de sentença relativa.................................................... 90

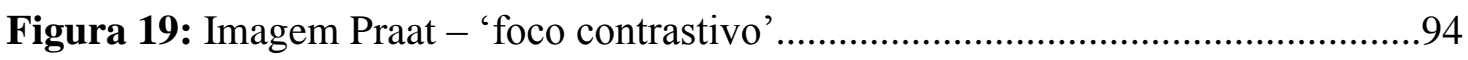

Figura 20: Imagem Praat- checagem de 'foco informacional' ....................................95

Figura 21: Imagem Praat- checagem de 'foco informacional' .....................................100 


\section{LISTA DE QUADROS}

Quadro 1: Emigração cabo-verdiana masculina e feminina para Portugal....................25

Quadro 2: População das ilhas de Cabo Verde................................................................27

Quadro 3: Versão 1 da Monogêneses: Monogêneses e o Pidgin-Português do Oeste

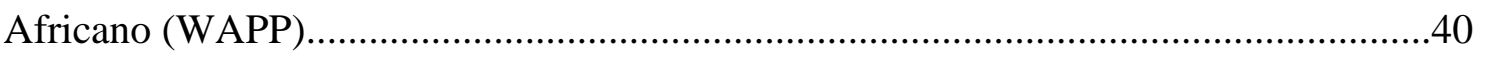

Quadro 4: Versão 2 da Monogêneses: Monogêneses e a Língua Franca........................40

Quadro 5: Primeira definição de pidgin segundo Bakker............................................43

Quadro 6: Segunda definição de pidgin segundo Bakker.............................................44

Quadro 7: parâmetros sociolinguísticos de diferenças entre pidgins, pidgincrioulos e crioulo.

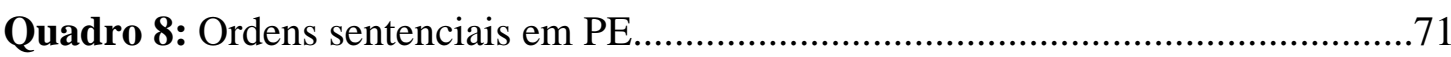

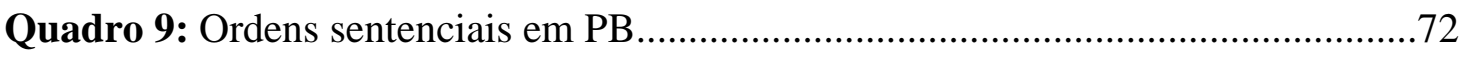

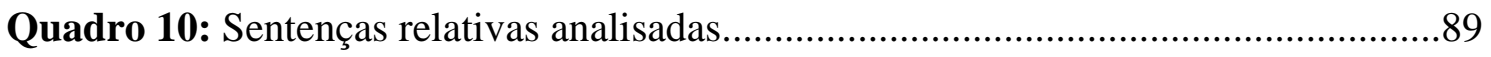

Quadro 11: Número de ocorrências tonais em sentenças relativas.............................91

Quadro 12: Número de ocorrências tonais em sentenças imediatamente posterior à

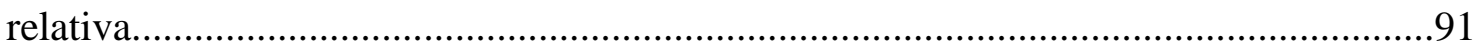

Quadro 13: Sentenças com 'foco contrastivo' .........................................................93

Quadro 14: Número de ocorrências tonais com foco contrastivo do constituinte

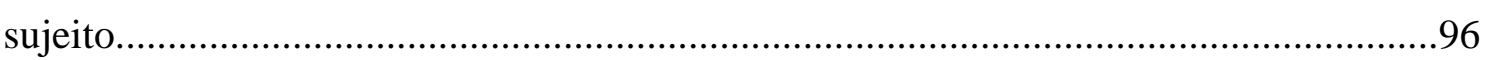

Quadro 15: Tipos de clivagens possíveis para ‘foco contrastivo’ em São Nicolau.......96

Quadro 16: Tipos de Clivagens em sentenças com 'foco contrastivo' - análise dessa

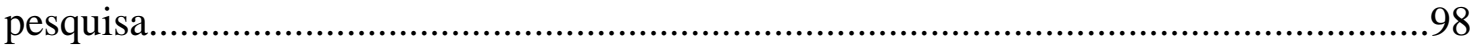

Quadro 17: sentenças clivadas com 'foco informacional' ...........................................98

Quadro 18: Ocorrências tonais em sentenças com 'foco de informação' ...................100

Quadro 19: respostas possíveis ou não para o ‘foco informativo' em São Nicolau....101

Quadro 20: Tipos de Clivagens em sentenças com 'foco informacional' - análise dessa pesquisa...... 102 


\section{INTRODUÇÃO GERAL}

Esta dissertação tem como objetivo principal o estudo preliminar das estratégias de 'foco' do constituinte 'sujeito' na língua cabo-verdiana - na variedade da ilha de São Nicolau, região de Barlavento. Propomos um alargamento da investigação desse tópico de estudo na língua em questão, partindo do estudo prévio de Lopes \& Zanoli (2012).

O arquipélago de Cabo Verde é um país africano cuja população, bem como sua língua nativa, o cabo-verdiano, 'resultam' diretamente do fenômeno da expansão ultramarina portuguesa, iniciada no século XV. Os contatos gerados a partir desse fenômeno, no qual falantes de diversas línguas e etnias foram confinados em um mesmo ambiente marcaram o 'surgimento' ds línguas denominadas crioulas.

Ao chegarem nas ilhas cabo-verdianas, no ano de 1460, os marinheiros portugueses, encontraram-as, segundo a maioria dos estudiosos, desabitadas. De início, as condições de solo precárias, associadas ainda ao clima desfavorável, com longos períodos de seca, tornavam a nova colônia desvaforável à agricultura. Entretanto, o arquipélago, acabou se tornando um rentável entreposto de comércio escravocrata.

Os escravos eram levados para as ilhas para serem ladinizados, ou seja, para conhecerem a fé dos colonizadores, e depois serem transportados para outras colônias portuguesas. Foi esse contato mais prolongado entre escravos e portugueses que favoreceu o surgimento da língua cabo-verdiana.

No que diz respeito a gêneses das línguas ditas crioulas, são consideradas duas hipóteses: a abrupta, segundo a qual a língua se forma num curto período de tempo entre 100 ou um pouco mais de 100 anos - e não abrupta, que afirma que a origem da língua deu-se por um período mais longo. O cabo-verdiano enquadra-se na teoria abrupta de formação.

Os estudos referentes à crioulística tiveram início a partir do século XIX. Entretanto, questões acerca da gêneses dessas línguas são amplamente discutidas na literatura e alvo de muita polêmica.

Delgado (2009: 62), por exemplo, destaca duas grandes posições teóricas no estudo dos crioulos: a 'dialetológica' e a 'substratista'. A primeira posição considera os crioulos como sendo simplificações de línguas europeias, enquanto a segunda defende que as línguas crioulas são produtos de hibridismo linguístico, em que novas espécies 
resultam do cruzamento de outras línguas (DELGADO, 2009: 62). É bastante cuidadoso ao classificar o cabo-verdiano em uma dessas posições.

No entanto, nesse trabalho, chamamos a atenção do leitor para as outras duas importantes abordagens teóricas: a 'universalista', que tem como precursor Dereck que identificou traços específicos no crioulo havaiano e propõe que esses fizessem parte de qualquer língua crioula, instaurando, assim, uma abordagem de cunho universalista nos estudos crioulistas na era moderna; e a 'gradualista', afirmando que a crioulização, em um grande número de casos, como o sranan, o haitiano e o jamaicano, não foi instantânea, mas passou por um processo gradual, estendido por um grande número de gerações de falantes - ver: (McWORTHER, 1992), (DeGRAFF, 2001), entre outros.

Nesse aspecto, diferentemente de Delgado, ressaltamos o fato de que, ao tomarmos a gêneses do cabo-verdiano, a única abordagem que não caberia seria a 'gradualista', haja vista que, conforme já mencionado anteriormente, língua em questão, enquadra-se na teoria da formação abrupta.

No que diz respeito aos estudos dessas línguas, seguindo Bakker (2003), que se baseou, principalmente, em parâmetros sociolinguísticos, inserimos as três categorias recentes da "crioulística/pidginística", instaurando, portanto, uma tripartição à conhecida bipartição pidgin/crioulo ao acrescentar o conceito de pidgincrioulo, com o intuito de salientar a polêmica e dificuldades que permeia a classificação dessas línguas.

Salientando ainda mais tal polêmica, no que diz respeito à ausência ou não de flexões morfológicas, enfocamos algumas particularidades linguísticas do caboverdiano de São Nicolau, logo, apresentamos, por meio da morfossintaxe nominal e verbal, dois aspectos desta língua a fim de cotejá-lo com o português. Na morfossintaxe nominal: o gênero e o número; na morfossintaxe verbal: a marcação de tempo, aspecto e modo, atestando marca de flexão verbal e também marcas de morfologia flexional na morfossintaxe nominal, tanto no 'gênero', quanto no 'número'.

No que diz respeito ao objeto de nossa pesquisa - centrado na checagem do foco do elemento sujeito - ressaltamos que essa delimitação se dá por ser esta posição de foco já bem estudada na literatura sobre o foco em língua portuguesa - tanto no português brasileiro, quanto no português europeu. Logo, por ser o cabo-verdiano uma língua tida de base lexical portuguesa, interessa-nos uma análise no tocante a esse tópico linguístico, a fim de termos uma comparação, ainda que muito sucintamente, com a língua portuguesa. 
Para a realização desse estudo, ao contrário do que atesta um grande número de estudiosos, que tratam, de modo geral, as clivadas como estruturas que contêm relativas, assumimos que nem toda construção contendo um elemento ensanduichado entre a cópula e o morfema 'que' pode ser analisada como contendo relativa. Tal abordagem é significativa para nossa proposta de foco para o cabo-verdiano, variedade de São Nicolau, haja vista que, como atestado em Lopes \& Zanoli (2012), e confirmado em nossas análises, em cabo-verdiano de São Nicolau, a marcação de foco do elemento sujeito, se dá unicamente por meio das clivadas. Logo, diferentemente do que apresentamos como característica do PE, que atesta sujeito posposto - capítulo (3), subseção (3.2.1) - em cabo-verdiano, tal como em PB, essa possibilidade não se confirma. Entretanto, a marcação de foco do elemento sujeito em cabo-verdiano, se diferencia também do PB, haja vista que esse pode marcar foco prosódico sem alterar a ordem das sentenças e sem se utilizar de clivagem.

Ratificamos ainda, o fato de que, nessa variedade de cabo-verdiano, as sentenças relativas, que não atestam marcação de foco, se diferenciam das clivadas, que como já apontado, é a única estrutura possível para checagem do foco do constituinte sujeito.

Desse modo, importa-nos chamarmos a atenção do leitor para o caso do elemento k’ nas sentenças relativas. Lopes (2012: capítulo 3), ao descrever a natureza dos elementos introdutores de orações relativas, na variedade da língua cabo-verdiana falada na ilha de São Nicolau, segue a proposta de De Vries (2002). Logo, para Lopes em sentenças tidas como relativas, o k' é tratado como 'complementizador relativo'. Assim, a classe dos pronomes relativos distingue-se, para o autor, da dos relativizadores, que não são tratados como pronomes, mas sim como complementizadores (C), e mais especificamente, como complementizadores relativos (COMPREL).

Diferentemente, Oliveira, Jorge \& Lopes (2013) demonstram uma ambiguidade teórica apontada em Lopes (2012) no tocante à nomenclatura/categorização que utiliza, a partir de De Vries (2002), ao tratar o k' das relativas como 'complementizador relativo'. Para Oliveira, Jorge \& Lopes (2013), como apontaremos no capítulo 4, subseção 4.1.1, ou um elemento é complementizador ou é pronome/relativizador. Assim, assumimos a proposta de que o k' das relativas, seja considerado pronome relativo $\left(\mathrm{PRO}_{\mathrm{REL}}\right)$ na língua, e em sentenças clivadas, tais partículas são consideradas como marcadoras de 'foco' [FOC]. 
Finalmente, com testes mais amplos, abrangendo um número maior de dados e de informantes, foi possível chegar a análises mais acuradas acerca do foco da posição de sujeito em São Nicolau. Apesar de corroborarmos a estrutura de clivagem como a única possibilidade de se realizar o foco nessa variedade, atestamos diferentes tipos de clivagens na marcação do foco.

Esta dissertação está dividida em 4 capítulos, além desta introdução.

No capítulo (1) abordamos o arquipélago de Cabo Verde, traçando panorama histórico desde o período da chegada dos portugueses às ilhas até o momento da colonização da Ilha de São Nicolau. Nesse enfoque, além de falarmos sobre aspectos históricos, falamos também, brevemente, um pouco da geografia e de aspectos físicos e climáticos das ilhas. Falamos também, ainda que sucintamente, da importância histórica da ilha de São Nicolau, pois, segundo fontes como Quinquin (2007), foi “precisamente nas suas aguas que navegaram os navios da armada de Pedro Alvares Cabral em viagem para o famoso e épico descobrimento do grande Brasil". Além disso, foi em São Nicolau que surgiu o primeiro Seminário-Liceu, que acabou por institucionalizar o ensino em Cabo Verde.

Finalmente, traçamos um breve panorama a respeito das lutas em favor da independência, e destacamos a importância da língua que ali se formou por ocasião da colonização, para a firmação da identidade do homem cabo-verdiano.

No capítulo (2) falamos sobre algumas hipóteses a respeito da gêneses das línguas crioulas, passando para uma abordagem mais recente sobre os conceitos de pidgin, crioulo e pidgincrioulo, enfatizando os parâmetros que Bakker (2003) utiliza para diferenciar os três sistemas linguísticos. Falamos ainda, a respeito da língua caboverdiana, em especial a variedade de Barlavento, enfocando aspectos da morfologia nominal, como 'gênero' e 'número', e a marcação do tempo (T), aspecto(A) e modo (M) na língua através das partículas TMA. Subsequentemente, traçamos um panorama sociolinguístico de Cabo Verde, abordando a complexa situação linguística do arquipélago em meio às duas línguas que convivem no mesmo espaço: o cabo-verdiano e o português.

No capítulo (3) apresentamos o referencial teórico-metodológico utilizado nessa dissertação, enfatizando, no tocante à sintaxe, a tipologia de foco conforme Zubizarreta (1997). Apresentamos, ainda, os resultados preliminares do trabalho realizado por Lopes \& Zanoli (2012) a respeito das estratégias de marcação de foco de informação e foco contrastivo da categoria sujeito no cabo-verdiano, na variedade de São Nicolau, 
utilizando, como parâmetros de comparação, estudos já realizados em PB e PE. O trabalho citado aponta que, em São Nicolau, não é possível que o foco seja expresso por outra maneira senão por meio da clivagem. Logo, apresentando também, neste capítulo, um breve resumo acerca da operação "clivagem".

Ainda no capítulo (3), no tocante à fonologia entoacional, adotamos a teoria Métrica Autossegmental para entoação, apresentando a perspectiva de Ladd (1996), para quem a fonologia entoacional consiste numa abordagem fonológica da estrutura entoacional da língua. Tal abordagem pressupõe que a entoação possui uma organização fonológica, conforme Pierrehumbert (1980); Beckman \& Pierrehumbert (1986); Pierrehumbert \& Beckman (1988); Hayes \& Lahiri (1991); entre outros.

Finalmente, no capítulo (4), aprofundamos o estudo da checagem de foco do constituinte sujeito realizado por Lopes \& Zanoli (2012) por meio da análise de um corpus maior, submetido à análise entoacional. Nesse estudo, tivemos por meta apontar diferenças e/ou semelhanças entre sentenças com foco contrastivo, informativo e sentenças relativas que contrapõem-se, portanto, a estruturas focalizadas. 


\section{CAPÍTULO 1}

\section{O ARQUIPÉLAGO DE CABO VERDE E A ILHA DE SÃO NICOLAU}

\subsection{Introdução}

O arquipélago de Cabo Verde é um país africano cuja população, bem como sua língua nativa - o crioulo de Cabo Verde - 'resultam' diretamente do fenômeno da expansão ultramarina portuguesa que levou à mestiçagem de europeus com africanos de diversas etnias nas ilhas cabo-verdianas.

No momento da chegada dos marinheiros portugueses, as ilhas encontravam-se desabitadas, e as condições de solo eram bastante reduzidas, portanto, pouco propícias à agricultura. Entretanto, o que chamou a atenção dos colonizadores, logo de início, foi a posição geográfica das ilhas, que, situadas 'na encruzilhada de três continentes Europa, África e as Américas' (VEIGA, 2002: 3), era muito favorável ao tráfico de escravos.

Descobertas em 1460, as ilhas foram povoadas com escravos vindos da costa ocidental africana e com portugueses, formando, desse modo, uma grande população mestiça, bem como uma cultura única influenciada por diversos povos (GOVERNO DE CABO VERDE, 2014). Foi nesse contexto que se originou o crioulo de Cabo Verde. A situação atual ainda é de grande mestiçagem: $80 \%$ da população é mestiça, $17 \%$ é negra, e apenas 3\% da população é branca - ver Cabo Verde (2013).

O arquipélago permaneceu como colônia de Portugal até 5 de Julho de 1975, quando alcançou sua independência após um longo período de guerras civis. Em 13 de Janeiro de 1990 foi introduzido oficialmente o sistema pluripartidário que levaria a um sistema democrático.

Nesse capítulo falaremos um pouco da formação histórica de Cabo Verde, do seu povo, sua cultura e língua, principal símbolo da identidade cabo-verdiana. Abordaremos também a formação da ilha de São Nicolau, cuja variedade linguística é o principal objeto de estudo desta dissertação. 


\section{$\star \star \star \star x$}

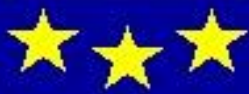

Figura 1: Bandeira de Cabo Verde

Fonte: Governo de Cabo Verde

\subsection{Cabo Verde - Aspectos Gerais}

O arquipélago de Cabo Verde é composto por dez ilhas, que, devido aos ventos dominantes, dividem-se em dois grupos: Barlavento e Sotavento. Ambos são termos náuticos, sendo que Barlavento corresponde ao lado onde sopra o vento e Sotavento corresponde ao lado oposto do qual o vento sopra ${ }^{1}$.

O grupo de Sotavento é composto pelas ilhas de Maio, Santiago, Fogo e Brava e o grupo de Barlavento é composto pelas ilhas de Santo Antão, S. Vicente, São Nicolau, Sal, Boavista e Santa Luzia (BAPTISTA, 2002:14).

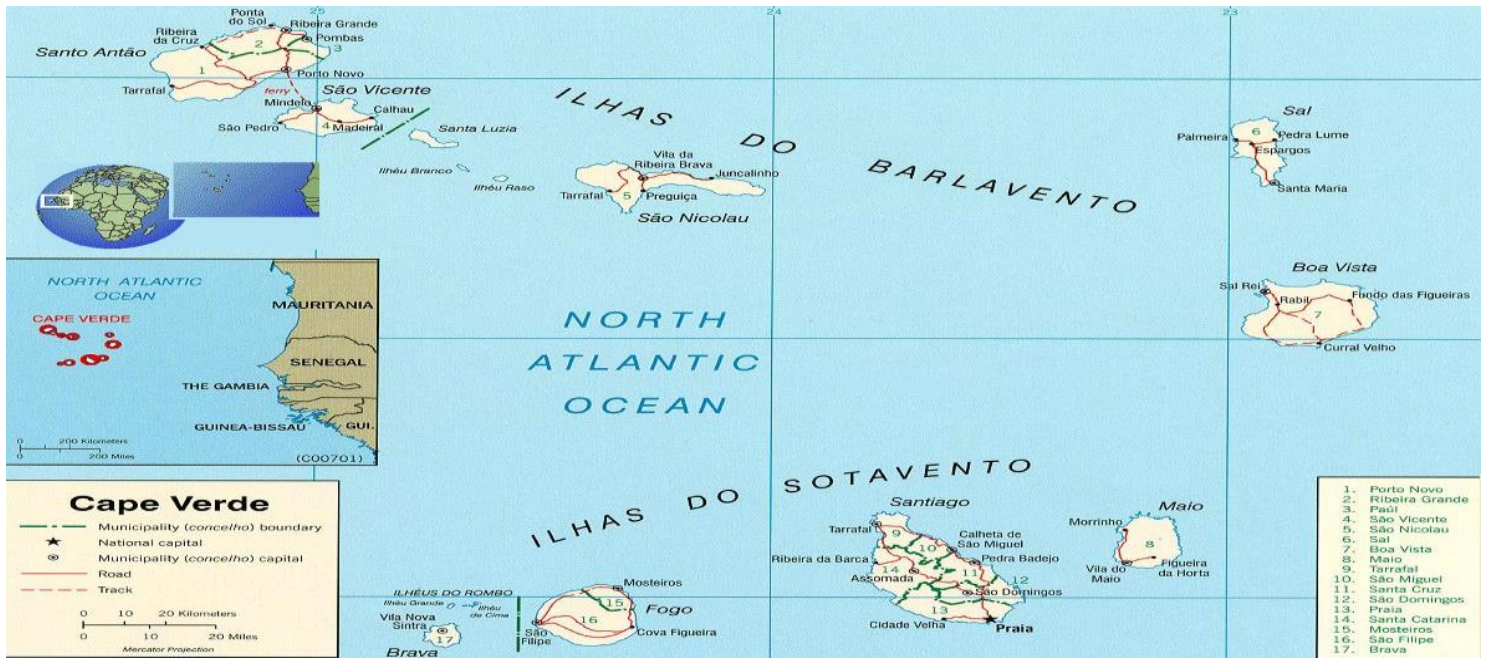

Figura 2: Cabo Verde: Ilhas de Barlavento e de Sotavento.

Fonte: Fonte: CIPPLOP (Comissão interpaíses Brasil - Portugal \& Países de língua oficial portuguesa)

${ }^{1}$ Governo de Cabo Verde 
Os dois grupos dialetais maiores, Barlavento e Sotavento, por sua vez, subdividem-se em áreas menores, visto que cada ilha possui seu próprio dialeto. Entretanto, cada grupo dialetal possui um epicentro linguístico principal: em Sotavento é a Ilha de Santiago, a primeira ilha a ser ocupada no arquipélago; Barlavento tem como variante principal a ilha de São Vicente - ver Lopes da Silva (1984: 36-37).

Segundo Pereira (2011:16), a área total do arquipélago é de $4033 \mathrm{Km}^{2}$ e sua população atual é de aproximadamente quinhentos mil habitantes. Porém, grande parte da população vive em diáspora. Na verdade, estima-se que o número de indivíduos em diáspora é maior do que o número de moradores nas ilhas. Dados apontam que os caboverdianos na diáspora (especialmente Europa Ocidental e Estados Unidos da América) chegam a mais de um milhão ${ }^{2}$.

O arquipélago de Cabo Verde, encontra-se situado cerca de $455 \mathrm{~km}$ de distância da costa ocidental africana, no oceano Atlântico. As ilhas foram formadas pela acumulação de rochas, resultantes de erupções vulcânicas sobre as plataformas submarinas. Algumas ilhas são áridas, mas outras possuem uma vegetação exuberante e tropical. O relevo da maior parte das ilhas é bastante acidentado, com altitudes que ultrapassam os mil metros em algumas ilhas, atingindo mesmo 2.882 metros na ilha do Fogo. As ilhas mais orientais ${ }^{3}$, por estarem expostas aos ventos secos e quentes do Sahara, possuem relevo mais plano e um clima mais árido ${ }^{4}$.

O clima das ilhas mais acidentadas é variado e com presença de alguma pluviosidade. É temperado devido a ação moderadora que o oceano e os ventos alísios exercem sobre a temperatura. As médias anuais raramente se elevam acima dos $25^{\circ} \mathrm{C}$, nunca descendo abaixo dos $20^{\circ} \mathrm{C}$. Essa estabilidade climática de Cabo Verde garante a possibilidade de turismo o ano todo ${ }^{5}$.

\footnotetext{
${ }^{2}$ Dados do Instituto Nacional das Estatísticas (INE) - ver INE (2013).

${ }^{3}$ Segundo Martins (2009: 17), Cortesão considerava as duas ilhas, Sal e Boa Vista, como sendo as mais orientais do arquipélago.

${ }^{4}$ Governo de Cabo Verde.

${ }^{5}$ Idem nota 5.
} 


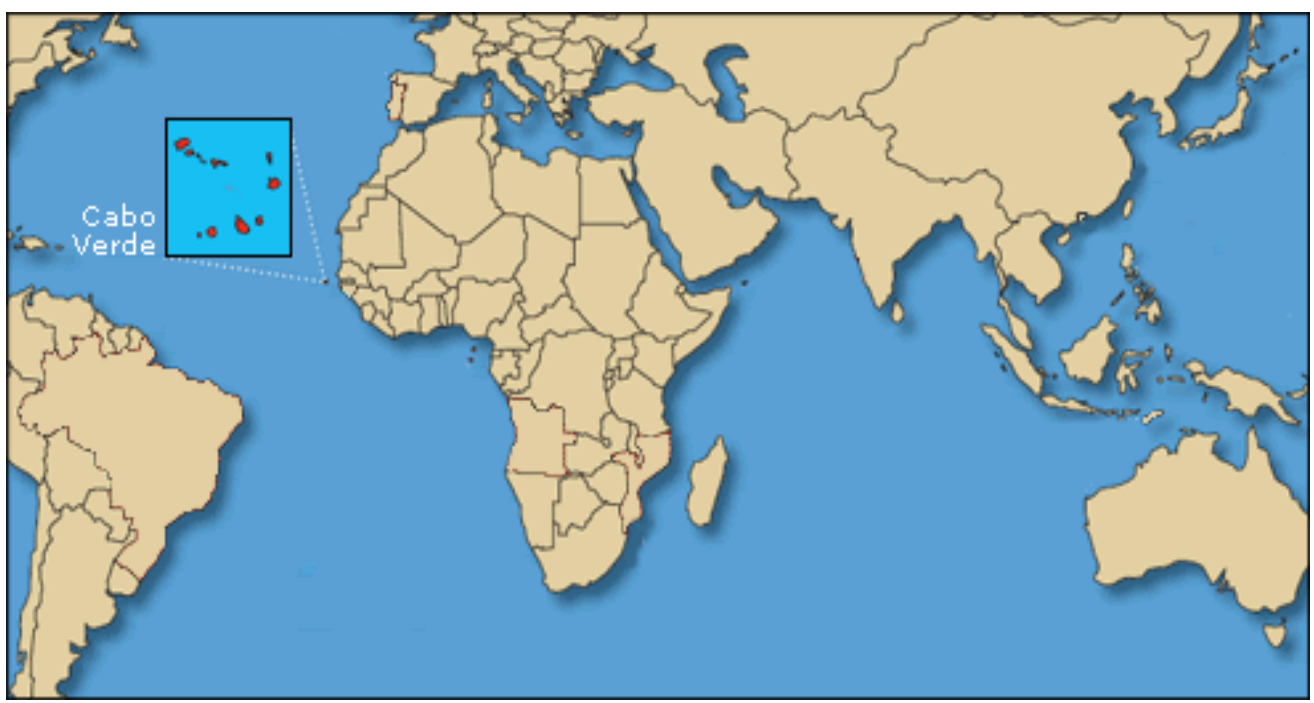

Figura 3: Posição de Cabo Verde no Mundo

Fonte: CIPPLOP (Comissão interpaíses Brasil - Portugal \& Países de língua oficial portuguesa)

A densidade populacional de Cabo Verde é de aproximadamente 119 habitantes por $\mathrm{km}^{2}$. A ilha de Santiago, a maior do arquipélago, é onde se localiza a capital do país (Cidade da Praia) e também é a ilha com maior número de habitantes. Esta foi a primeira ilha a ser habitada e preserva aquele que é considerado o crioulo mais próximo do protocrioulo que deu origem ao crioulo de Cabo Verde e de outros crioulos da Alta Guiné - ver Jacobs (2010).

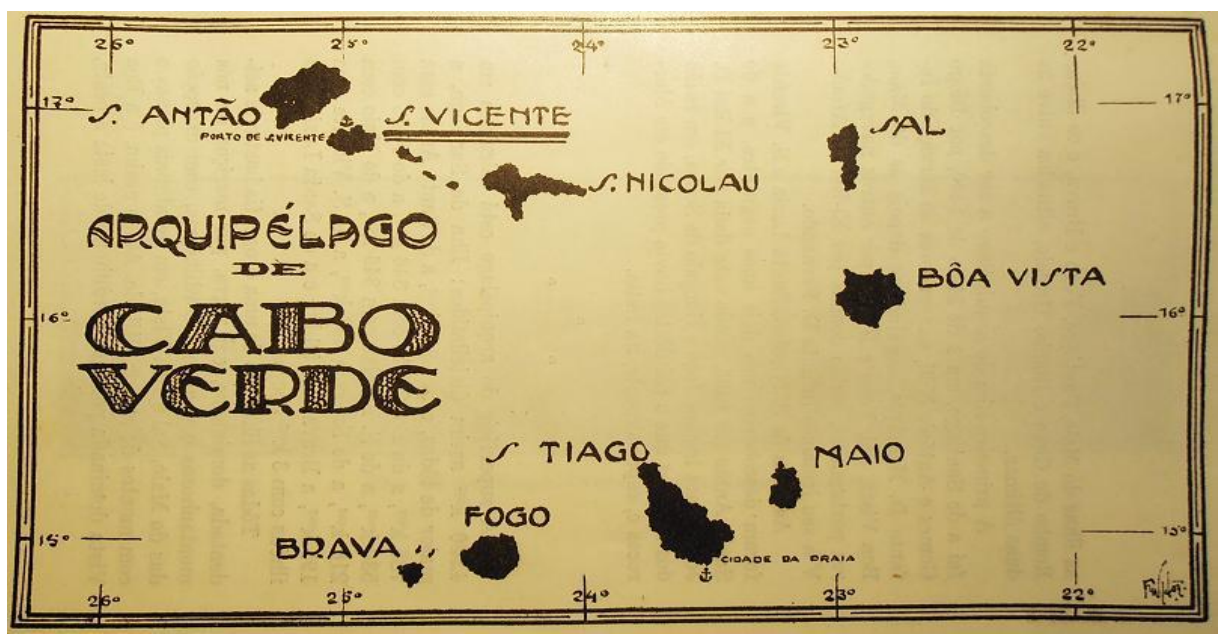

Figura 4: Arquipélago de Cabo Verde

Fonte: Marinha de Cabo Verde 


\subsubsection{A chegada dos portugueses nas ilhas de Cabo Verde}

Os marinheiros portugueses desembarcaram no arquipélago de Cabo Verde na segunda metade do século $\mathrm{XV}$, encontrando, segundo o consenso mais comum, todas as ilhas desabitadas.

Entretanto, Martins (2009: 17) afirma que, segundo alguns historiadores, as ilhas já seriam conhecidas pelos africanos, gregos e geógrafos árabes antes mesmo da chegada dos portugueses.

Para Cortesão (1962: 47), as ilhas também já eram conhecidas por alguns cartógrafos, uma vez que:

"nos mapas que acompanharam a obra de Idrisi, figuravam algumas das ilhas, uma das quais tinha o nome de Aulil: alguns séculos mais tarde, o mapa-mundo de Macias de Viladestes de 1413, que se encontra na Biblioteca Nacional de Paris, apresenta em frente do Rio do Ouro, claramente identificado como sendo o Nilo do Ghana, isto é, o Senegal, duas ilhas de tamanho e forma iguais, com o nome de Ilhas de Gaderi no mapa mundo de Andrea di Bianco de 1448. Estas mesmas ilhas aparecem de novo frente à costa entre o Senegal e Cabo Verde, com o nome de Dos Hermanos".

(CORTESÃO, 1962: 47)

A despeito desses testemunhos, em geral, assume-se que as ilhas de Cabo Verde foram encontradas pelos portugueses em duas viagens: a primeira em 1461 e a segunda em 1462. Essas datas são conhecidas através dos seguintes documentos (MARTINS, 2009: 17):

- num que consta do diploma de 3 de Dezembro de 1460 e faz referência às cinco primeiras ilhas do grupo ocidental: Sam Jacob (Santiago), Sam Filipe (Fogo), De las Mayes (Maio), Sam Christovam (Boavista) e Lana (Sal) que D. Afonso V doou a seu irmão D. Fernando logo após a morte do Infante D. Henrique;

- e na Carta de Doação de 19 de Setembro de 1462 que se refere às cinco ilhas acima mencionadas, às cinco restantes que foram descobertas na segunda viagem e também aos dois ilhéus: ilha Brava, ilha de Sam Nicolau (São Nicolau), ilha de Sam Vicente (São Vicente), ilha Rasa (ilhéu Raso), ilha Branca (ilhéu Branco), ilha de Santa Luzia e a ilha de Sant'Antonio (Santo Antão). 
Quanto aos descobridores, a maioria dos estudiosos considera que o genovês António de Noli, a serviço do Infante D. Henrique, e o navegador português Diogo Gomes descobriram as cinco primeiras ilhas. A descoberta das demais é atribuída a Diogo Afonso, escudeiro do Infante D. Fernando.

$\mathrm{O}$ projeto inicial era povoar as ilhas recém-descobertas à mesma maneira das outras ilhas atlânticas, ou seja, a ideia era promover um povoamento europeu. O desejo não se realizou devido à grave crise financeira que atingia a coroa portuguesa na época.

Quando D. Fernando recebeu as ilhas em doação, recebeu também o dever de povoá-las, e um dos primeiros a se instalar em Santiago foi António de Noli, no ano de 1462, juntamente com membros de sua família e alguns portugueses provenientes do Alentejo e do Algarve. Instalaram - se na Ribeira Grande, iniciando, assim, o primeiro povoado cabo-verdiano (BRÁUSIO, 1962: 77).

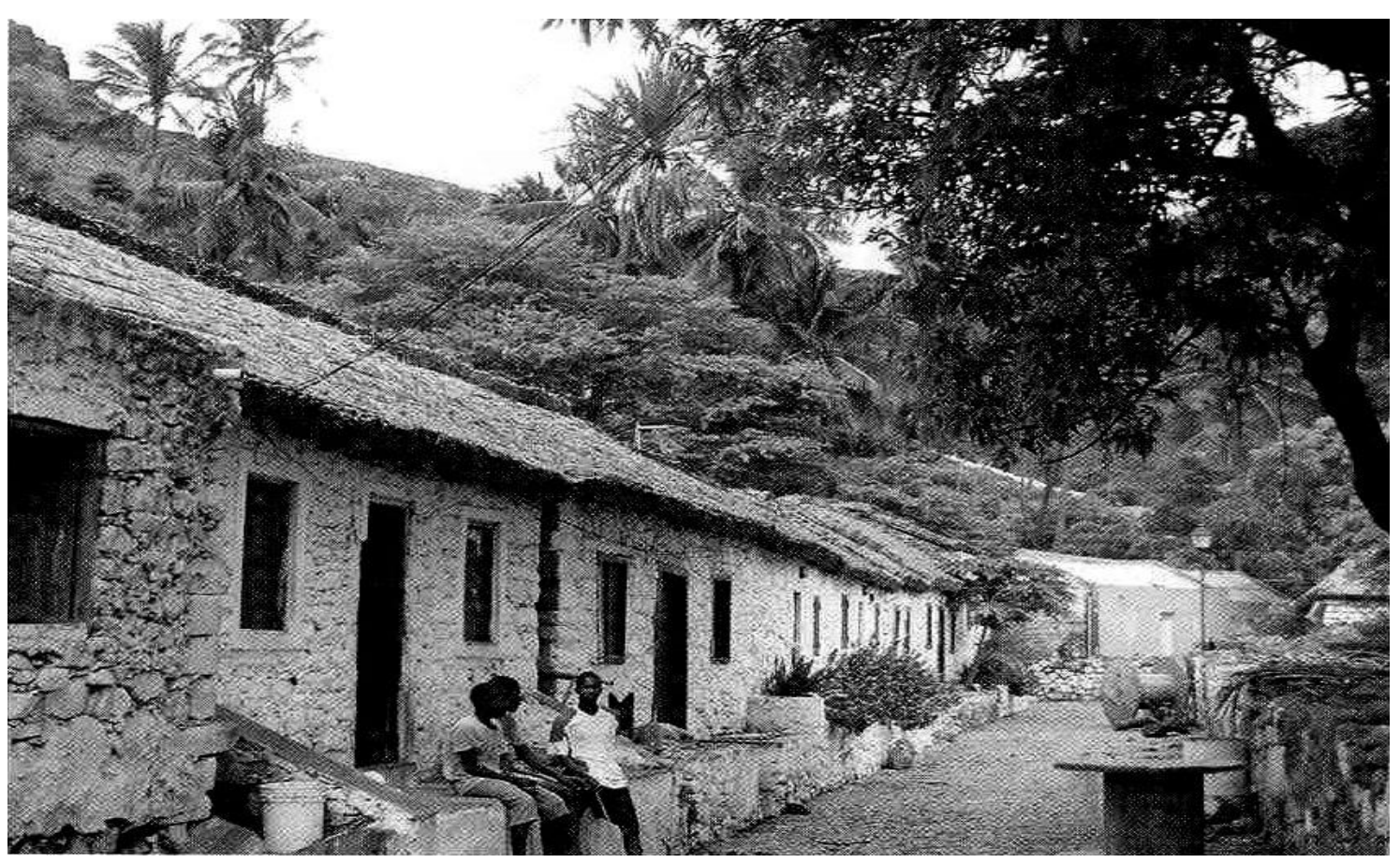

Figura 5: Ribeira Grande de Santiago, sede da Capitania Sul doada a António de Noli A Primeira Rua denominada Rua da Banana.

Fonte: Lourenço Gomes (2010) ${ }^{6}$

A ilha de Santiago foi dividida por D. Fernando em duas capitanias: a do Sul, com sede na Ribeira Grande (atual Cidade Velha), concedida a António de Noli; e a

\footnotetext{
${ }^{6}$ António de Noli, o descobridor oficial e primeiro povoador das ilhas de Cabo Verde. Jornada Internacional de estudos sobre António di Noli - descobridor de Cabo Verde, por acasião do $550^{\circ}$ aniversário.
} 
capitania do norte, sediada em Alcatrazes (atual Praia), a Diogo Afonso. Ambos receberam junto com a capitania o título de capitães-donatários das respectivas propriedades. Cargo que lhes dava o direito de cobrarem impostos (recolhidos sob forma de contribuição pelo rei) e conceder as terras em regime de sesmarias. Desse modo, a fim de dar continuidade ao povoamento das ilhas, os sistemas de Morgadios ${ }^{7}$ e Capelas $^{8}$ foram introduzidos em Santiago. Esse sistema foi abolido somente em 1864 ver Martins (2009:18). Notamos aqui a mesma visão imperialista, empregada pelos portugueses no Brasil, com o sistema de capitanias.

A peste negra que assolou a Europa no século XIV (fato que diminuiu drasticamente o crescimento populacional em Portugal), afetou também o povoamento do arquipélago de Cabo Verde. Assim, para conseguir promover a imigração europeia, D. Fernando solicitou ao irmão D. Afonso V maiores liberdades e privilégios, especialmente no que se referia à mão-obra-escrava.

Os pedidos de D. Fernando foram atendidos através da Carta Régia assinada em 12 de junho de 1466 que concedia a D. Fernando alguns poderes, como por exemplo, o direito de fazer comércio e tráfico de escravos em todas as regiões da Costa da Guiné ver Martins (2009: 20).

Posteriormente, outra carta assinada em 1472 (a Carta de Declaração e limitação dos privilégios), limitou as vantagens concedidas pela carta anterior. Conforme imposições desta carta, os habitantes de Cabo Verde eram impedidos, por exemplo, de utilizar mercadorias não produzidas nas ilhas, restringindo, portanto, as possibilidades de trocas. Limitou-se ainda a aquisição de escravos: os mesmos somente poderiam ser importados para suprir as necessidades internas. Tal limitação jamais foi respeitada.

Além disso, a Carta de Declaração e Limitação dos privilégios determinou também que os navios que interligavam a costa africana deviam pertencer aos habitantes de Cabo Verde ou, ao menos, serem armados por eles. Proibiu-se ainda o fretamento de navios não registrados em Santiago. Ressaltamos que as imposições dessa carta iniciou o conflito entre os interesses da coroa e os homens das novas terras de Cabo Verde.

\footnotetext{
${ }^{7}$ Segundo Couto (2001, p.80), o sistema de "morgadio" se caracterizava por um conjunto de bens inalienáveis e indivisíveis, indissoluvelmente ligados a uma família. Esta forma de propriedade era transmitida em linha masculina pelo primogênito. Os demais irmãos eram excluídos e apenas recebiam subsídios tirados do rendimento do morgado, possuidor do vínculo e administrador dos bens que o integravam.

${ }^{8}$ A "capela" era constituída por um conjunto de bens ligados à continuidade de um culto, que se caracterizava como um tipo de morgado na medida em que, por estar indissoluvelmente ligada a uma família, esta cumpria os deveres religiosos inerentes ao culto e, deste modo, usufruía desses bens (COUTO: 2001, p.80).
} 
No que diz respeito ao povoamento das ilhas, Martins (2009: 20), afirma que, para as ilhas, não foram mandados apenas escravos africanos, afinal, houve negros livres, chamados banhuns, cassangas e brames, que acompanhavam livremente os comerciantes, mercenários e os capitães dos navios. Alguns deles sabiam falar a língua portuguesa, outros chegavam a Santiago para serem cristianizados. Foram enviados ainda condenados e deportados políticos.

A ilha do Fogo foi a segunda a ser povoada no final do século XV. São Vicente e Sal foram as duas últimas já na terceira década do século XIX (MARTINS, 2009: 21). A população de cada ilha possuía características próprias, haja vista que seus moradores apresentavam diferenças de comportamento, hábitos, tradições e estilo de vida. Até mesmo o crioulo em cada ilha sofria diferenças locais.

No decorrer do século XVI, as outras ilhas permaneceram praticamente desabitadas. Apenas no século XVII, essas ilhas passaram a ser exploradas. As ilhas de Santo Antão, Boa Vista, Maio, São Vicente e São Nicolau, por exemplo, começaram a receber alguns moradores, pois, por serem mais propícias à agricultura e à pecuária do que Santiago, os habitantes decidiram aproveita-las para a criação bovina, caprina e ovina.

As ilhas de Boa Vista, Maio e Sal não foram aproveitadas apenas na criação de gado, mas também na extração do sal, cultivo e comércio de urzela ${ }^{9}$ e algodão destinados à indústria de tecelagem.

As ilhas de Santo Antão, São Vicente e São Nicolau foram inicialmente submetidas a um sistema de exploração pecuária intensiva e posteriormente (a partir do século XVII), ao sistema de povoamento com negros e mestiços, e entre os séculos XVIII e XIX, essas ilhas receberam os estrangeiros brancos (MARTINS, 2009:21).

A preocupação com o povoamento e a posição geográfica de Cabo Verde, "na encruzilhada de três continentes - Europa, África e Américas" (VEIGA, 2002: 5), fez com que o arquipélago passasse a ser considerado um ponto estratégico na concorrência das rotas marítimas entre os continentes europeu, africano e americano, ganhando um papel fundamental para a expansão portuguesa (MARTINS, 2009: 37). A ocupação das ilhas facilitou a criação de um entreposto comercial e de abastecimento dos navios. Além disso, facilitava muito o tráfico de escravos, que se tornou o comércio mais

\footnotetext{
${ }^{9}$ Nome popular de uma espécie de líquen, da família das Roceláceas, nativo em rochas costeiras das ilhas da Madeira, Açores e Cabo Verde. Produz um corante de coloração púrpura, que antigamente era de grande valor, pois era usado para tingir têxteis. O nome científico é Roccella Tinctoria.
} 
lucrativo da época. Esse comércio transformou, rapidamente, as ilhas num centro de concentração de populações.

Em São Vicente, o Porto Grande, por exemplo, estava estrategicamente localizado, pois situava-se em meio as rotas vindas da África do Sul e do Brasil, e visto que a maior parte dos navios portugueses da época eram movidos à carvão, o porto se transformou num dos principais depósitos de hulha negra ${ }^{10}$ do atlântico sul.

Assim, de acordo com Martins (2009: 37), essa foi uma fase na qual os moradores das ilhas viviam praticamente dependentes dos rendimentos cobrados aos navios que transportavam mercadorias e escravos, ou seja, os negócios dependiam cada vez mais das rotas marítimas. Nesta fase os participantes da dinâmica de se abastecerem de escravos no entreposto negreiro foram os próprios moradores ou os homens que passavam pelas ilhas em caráter estável ou duradouro. Tais escravos eram distribuídos para trabalharem na produção de algodão, couro de animais e outras mercadorias produzidas no arquipélago (MARTINS, 2009: 37).

Em outra fase, com a expansão dos negócios, verificou-se "a entrada dos grandes mercadores de Sevilha e Lisboa, realizada por mandatários e feitores de contratadores. Consequentemente, houve a subalternização dos moradores que antes ocupavam posição principal” (MARTINS, 2009: 37). No início do século XVI, arquipélago exportava peles, couros, sebo, algodão, cavalos e açúcar de boa qualidade, produzido com a cana de açúcar importada da Madeira.

Em meados do século XIX, a quantidade de produtos exportados aumentou. Cabo Verde exportava, além de escravos, também algodão, peles, couros, tartarugas, milho, aguardente, sangue-de-drago ${ }^{11}$, tabaco, urzela $^{12}$, óleo de purgueira ${ }^{13}$ e sal.

Ademais, os portugueses centralizaram em Cabo Verde as comunicações telegráficas e comunicações postais internacionais, ligando os países do hemisfério Sul com os do Norte. Em 1912, foi inaugurado na Cidade da Praia o posto de radiotelegrafia e em 1916, durante a Grande Guerra, o posto passou a ser operado por Alberto Carlos

\footnotetext{
${ }^{10}$ Carvão fóssil.

${ }^{11}$ Uma espécie de resina vermelha produzida pelo dragoeiro arborescente dos países quentes.

${ }^{12}$ Ver nota 9.

${ }^{13}$ Desde que foi introduzida a utilização da purgueira nas ilhas de Cabo Verde (na produção de velas, sabão, óleo de iluminação) expandiu-se para Europa, e desde então o desenvolvimento da sua cultura foi constante. Em 1843, a cultura desta planta tornou-se obrigatória por parte dos habitantes da Boavista e Santo Antão.
} 
de Oliveira, intermediador entre a esquadra inglesa e o almirantado em Londres, recebendo e retransmitindo as mensagens que chegavam a Cabo Verde ${ }^{14}$.

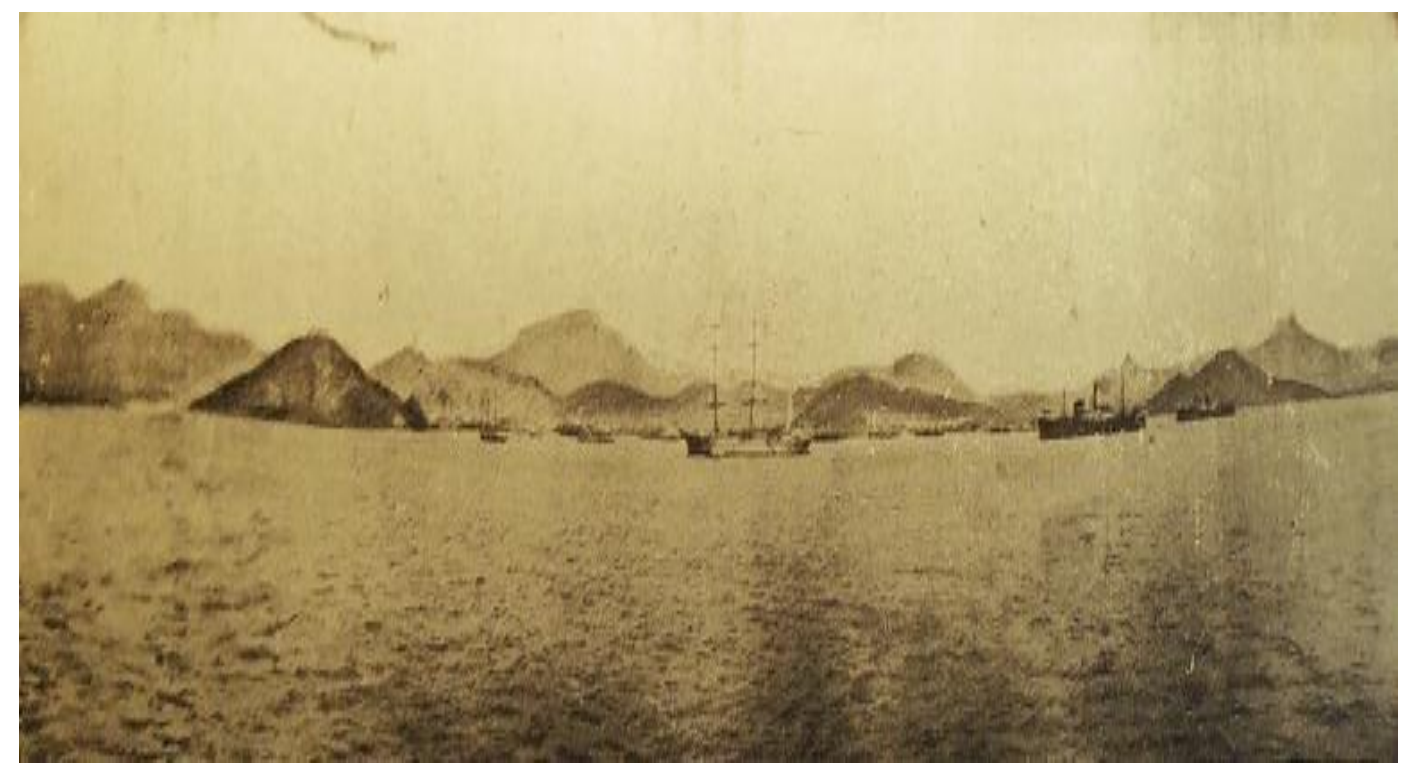

Figura 6: Ilha de São Vicente - vista da entrada do Porto Grande

Fonte: Marinha de Cabo Verde

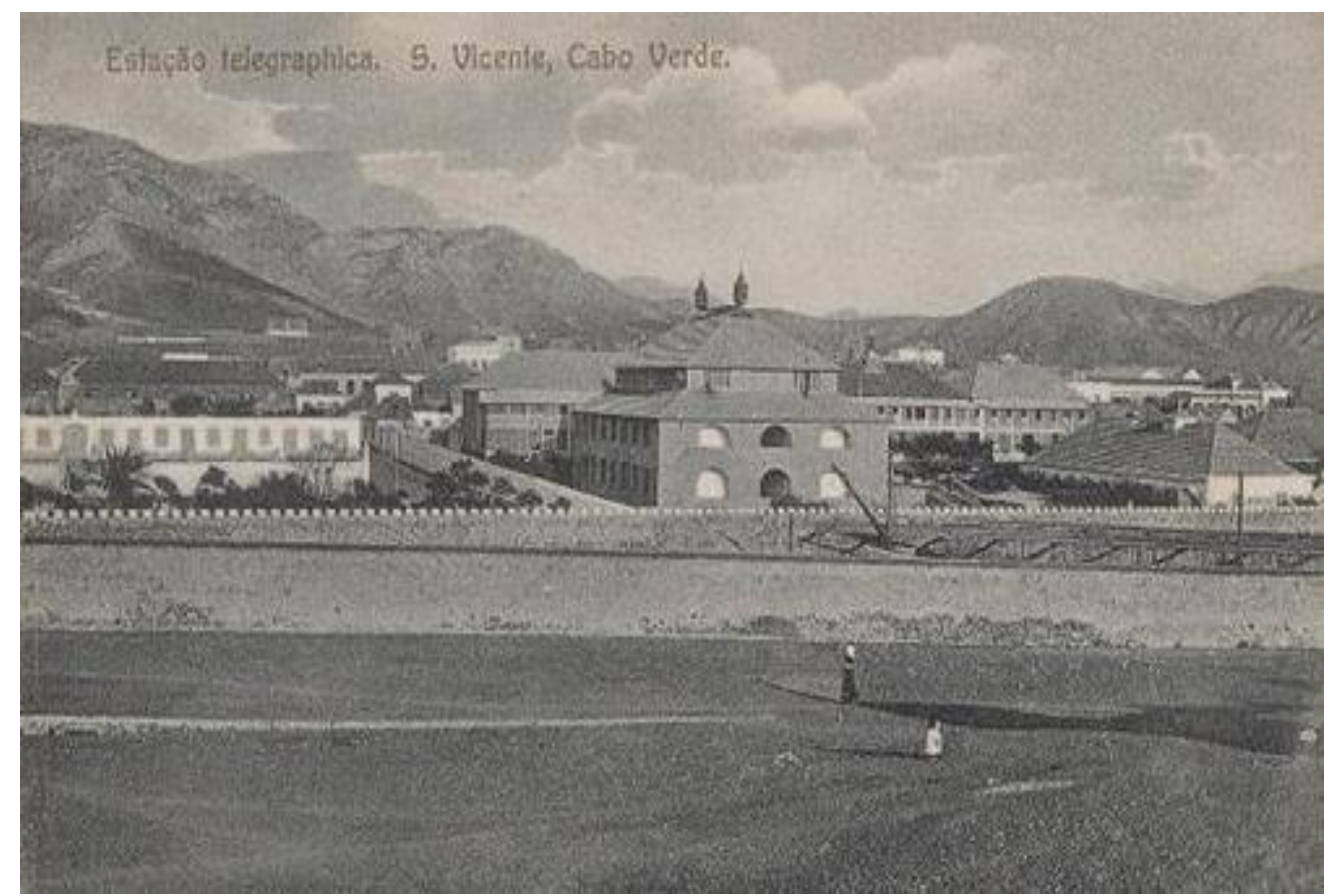

Figura 7: Posto telegráfico de São Vicente

Fonte: Marinha de Cabo Verde

\footnotetext{
${ }^{14}$ Marinha de Cabo Verde.
} 


\subsubsection{Diáspora Caboverdiana}

\section{Ora di bai}

Ora di bai

ora di dor,

Ja'n q'ré

Pa el ca manchê!

De cada bez

Que 'n ta lembrâ,

Ma'n q'ré

Ficâ 'n morrê!

Ora di bai,

Ora di dor

(...)

\section{Hora da partida,}

Hora da partida

Hora de dor,

É meu desejo

Que não amanheça! (não chegue a hora)

De cada vez

Que a lembro,

Prefiro

Ficar e morrer!

Hora de partida,

Hora de dor!

(...)

(TAVARES, 1969, p. 41-42)

De modo geral, as condições de vida nas ilhas cabo-verdianas são bem difíceis, embora grandes esforços vêm sendo feito por parte do governo visando à melhora da qualidade de vida. O solo do arquipélago é pobre, marcado por terrenos montanhosos e declives bem acentuados. Além disso, secas periódicas agravam ainda mais a situação. A última, ocorrida em 1947- 48 matou cerca de 30 mil indivíduos (PEREIRA,2011: 17).

Fatores econômicos como baixos salários e alta taxa de desemprego também contribuíram para que milhares de cabo-verdianos abandonassem o país em busca de melhores oportunidades no exterior. Tantos são os indivíduos em diáspora, que se estima um número maior do que os moradores nas ilhas.

Carreira (1983: 63) defende que a imigração para os EUA se iniciou entre os anos de 1685 e 1700, com o emprego de pescadores de baleias cabo-verdianos nos baleeiros norte-americanos que paravam para abastecer no arquipélago.

De acordo com Carreira (1983: 77), a diáspora caboverdiana teve várias etapas:

1. Emigração forçada;

2. Emigração espontânea, dividido em três fases:

2.1. Período de 1900 a 1920;

2.2. Período de 1927 a 1945 ; 


\subsection{Período de 1946 a 1973.}

A fase da emigração forçada, ocorrida entre 1902 a 1970, de acordo com o autor, foi impulsionada por iniciativa do governo colonial português que promulgou leis que tinham por finalidade recrutar mão-de-obra braçal para as 'roças' em São Tomé e para outras colônias africanas.

Na primeira fase da emigração espontânea, no período de 1900 a 1920, o destino escolhido pelos cabo-verdianos foram os Estados Unidos. No segundo período, 1927 a 1945, ocorreu uma diminuição das saídas e também uma mudança de rumo: o destino passou a ser a África, visto que as leis norte-americanas sofreram alterações nos anos de 1919, 1924 e 1928 que restringiram a entrada de indivíduos analfabetos, situação bastante comum entre os cabo-verdianos.

Finalmente, na terceira fase emigratória (1946 a 1973), verificou-se grande êxodo e os emigrantes cabo-verdianos escolheram a Europa como destino, mais especificamente Portugal, França, Holanda e Itália.

Diferentemente de Carreira (1983), Andrade (1996: 181) classifica as fases de emigração em antiga e moderna, que correspondem a dois períodos: (i) anterior à II Guerra Mundial; e (ii) posterior a esse acontecimento.

A autora defende a ideia que a corrente de emigração antiga corresponde às saídas para a Guiné, Senegal e Estados Unidos. De acordo com Andrade (1996: 181), 2 após a Conferência de Berlim (1885), os cabo-verdianos continuaram a emigrar para a Guiné em busca de empregos em repartições públicas. Assim, "entre 1920 e 1940, mais de $70 \%$ dos empregos na Guiné-Bissau eram ocupados por cabo-verdianos ou seus descendentes" (ANDRADE, 1996: 184). Nessa época também aconteceu a emigração para o Senegal, subsistindo até a segunda metade do século XX com os que a autora chama de "luso-africanos" (ANDRADE, 1996:186)"

A emigração moderna iniciou-se, de acordo com a autora, após a II Guerra Mundial, momento em que o campo migratório se expandiu para regiões semiindustrializadas do continente africano. Também em Portugal, nesse período, registrouse uma maior procura por parte dos cabo-verdianos, principalmente a partir da década

\footnotetext{
${ }^{15}$ A designação "luso-africanos", de acordo com Andrade (1996: 186), faz referência aos negreiros e aos lançados portugueses e cabo-verdianos, mais tarde mestiços e negros livres ou libertos, que se juntaram a eles e se fixaram em seguida na Senegâmbia e na costa. Eram conhecidos por «luso-africanos» por se considerarem de origem portuguesa, mesmo quando eram mestiços ou negros.
} 
de 60 (Andrade, 1996: 186). Tratava-se de uma maneira de compensar a falta de mãode-obra resultante da própria emigração portuguesa.

A emigração feminina também aconteceu, de forma bastante acentuada, a partir da década de sessenta, e o destino era Itália, e outros países europeus como Holanda, França e Portugal. Abaixo apresentamos um quadro retirado de Martins (2009:91) comparando dados da emigração feminina com a masculina para Portugal no período entre 1985 e 2003.

\begin{tabular}{|c|c|c|}
\hline \multicolumn{3}{|c|}{ População cabo-verdiana residente em Portugal desde 1985 - 2003 } \\
\hline Ano & Homens & Mulheres \\
\hline 1985 & $64,4 \%$ & $35,6 \%$ \\
\hline 1990 & $62,2 \%$ & $37,8 \%$ \\
\hline 1995 & $60,8 \%$ & $39,2 \%$ \\
\hline 2000 & $58,1 \%$ & $41,9 \%$ \\
\hline 2003 & $56,3 \%$ & $43,7 \%$ \\
\hline
\end{tabular}

Quadro 1: Emigração cabo-verdiana masculina e feminina para Portugal

Fonte: Martins, 2009: 91

Mais recentemente, segundo dados do INE (Instituto Nacional de Estatísticas), os principais destinos da emigração cabo-verdiana têm sido:

- Estados Unidos: 250.000 (Boston, New Bedford);

- Portugal: 100.000;

- Holanda: 37.500;

- Angola: 35.000;

- Senegal: 22.500 .

Contudo, de acordo com Martins (2009: 95), o padrão da emigração caboverdiana está mudando. De acordo com a autora, os indivíduos em diáspora possuem níveis de escolaridade mais elevados, fato que permite uma inserção diferenciada no mercado de trabalho. 


\subsubsection{Dados demográficos de Cabo Verde}

De acordo com estimativas do Instituto Nacional de Estatísticas (INE) de Cabo Verde, há cerca de 480.000 habitantes (estimativas do ano de 2006) numa proporção de $48 \%$ de homens e $52 \%$ de mulheres. A maioria da população concentra-se nos meios urbanos $(55 \%)$.

A ilha mais populosa é Santiago, com mais de 50\% dos habitantes, seguida por São Vicente, com $15 \%$ e Santo Antão com $11 \%$.

No ano de 2005, de acordo com o INE, $40 \%$ da população cabo-verdiana tinha entre 0-14 anos e apenas 6\% tinha acima de 60 anos.

Ainda segundo o INE, em 1975, a média de vida do cabo-verdiano atingia os 63 anos, subindo para 71 (67 para homens e 75 para mulheres) em 2003. A taxa de mortalidade infantil, que em 1975 rondava os 1100/00 nascimentos vivos, caiu pra 440/00 em 1990, 260/00 em 2000, e, em 2004, representava um valor de 200/00. Valor inferior às taxas de outros países de categoria de rendimento semelhante.

Segundo o INE, no que se refere à taxa de crescimento da população, que depende dos fluxos migratórios, situou-se, entre os anos de 1990-2000, em torno de 2,4\%. Esse valor se manteve constante até 2005. Os agregados familiares, em 2006, eram constituídos, em média, por 4,9 membros (5 no meio rural e 4,5 no meio urbano).

Abaixo segue o quadro do número de habitantes nas ilhas de Cabo Verde, medidos em um intervalo de cinco anos, sendo o último em 2010.

\begin{tabular}{|l|l|l|l|}
\hline Barlavento: & $\mathbf{2 0 0 0}$ & $\mathbf{2 0 0 5}$ & $\mathbf{2 0 1 0}$ \\
\hline Boa Vista & 4.209 & 5.398 & 6.800 \\
\hline Sal & 14.816 & 17.631 & 35.000 \\
\hline Santo Antão & 47.170 & 47.484 & 47.602 \\
\hline São Nicolau & 13.661 & 13.310 & 12.816 \\
\hline São Vicente & 67.163 & 74.136 & 82.127 \\
\hline Sotavento: & $\mathbf{2 0 0 0}$ & $\mathbf{2 0 0 5}$ & $\mathbf{2 0 1 0}$ \\
\hline
\end{tabular}




\begin{tabular}{|l|l|l|l|}
\hline Brava & 6.804 & 6.462 & 6.016 \\
\hline Fogo & 37.421 & 37.861 & 38.187 \\
\hline Maio & 6.754 & 7.506 & 8.370 \\
\hline Santiago & 236.627 & 266.161 & 300.262 \\
\hline
\end{tabular}

Quadro 2: População das ilhas de Cabo Verde

Fonte: INE

Na próxima subseção passaremos a discorrer a respeito da ilha de São Nicolau, objeto de estudo desta dissertação.

\subsection{Ilha de São Nicolau}

A ilha de São Nicolau é situada na região de Barlavento. Tem uma população de aproximadamente 14.000 pessoas em uma área de $346 \mathrm{~km}^{2}$. Suas coordenadas são:

- Latitude $16^{\circ} 29^{\circ} \mathrm{N}$ e $16^{\circ} 40^{\circ} \mathrm{N}$

- Longitude: $24^{\circ} 00^{\prime} \mathrm{W}$ e $24^{\circ} 25^{\prime} \mathrm{W}$

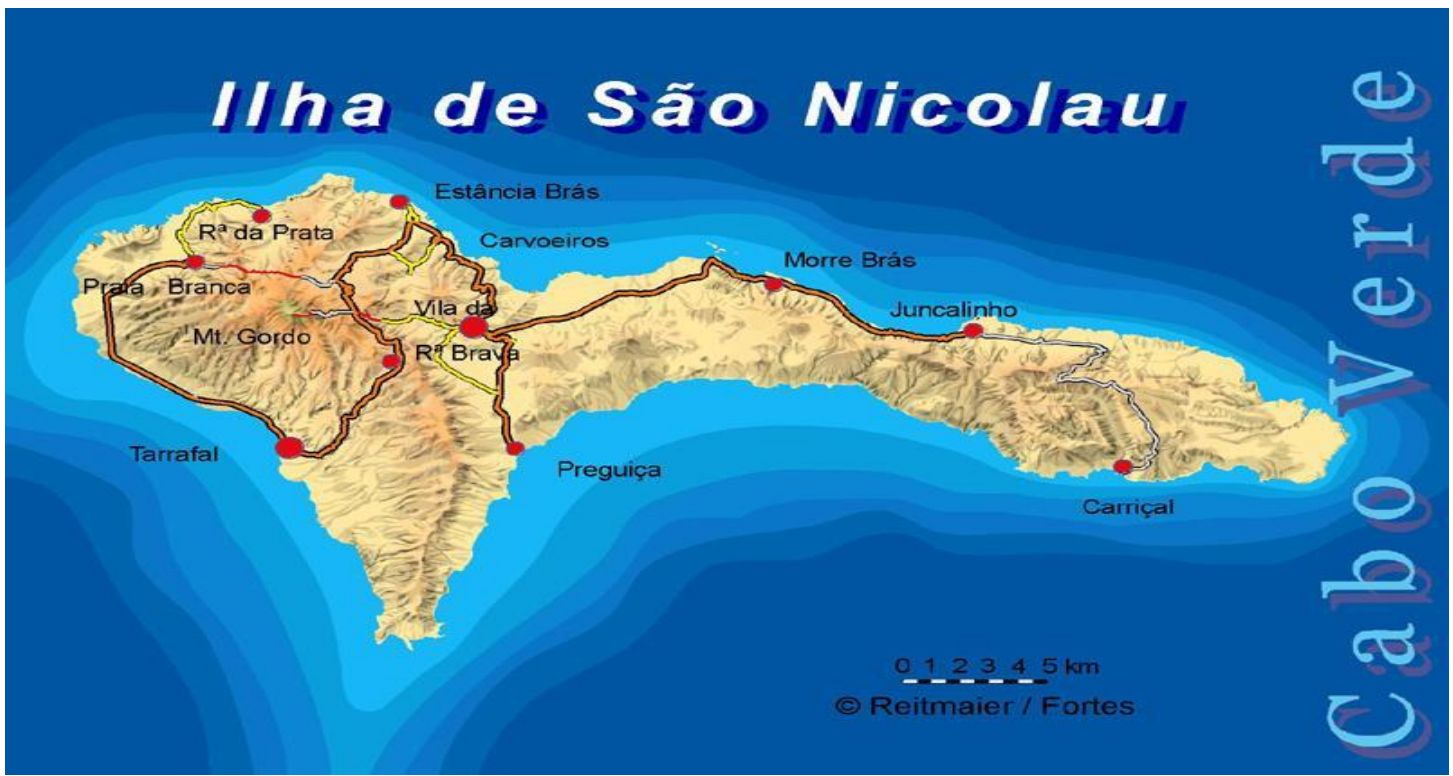

Figura 8: Ilha de São Nicolau

Fonte: Wikipédia 
De acordo com a história, a ilha de São Nicolau foi descoberta em dezembro de 1461 por Diogo Afonso, sendo, porém povoada somente em 1510 por escravos vindos da ilha da Madeira. Abaixo apresentamos uma figura representando o povoamento de São Nicolau em 1897:

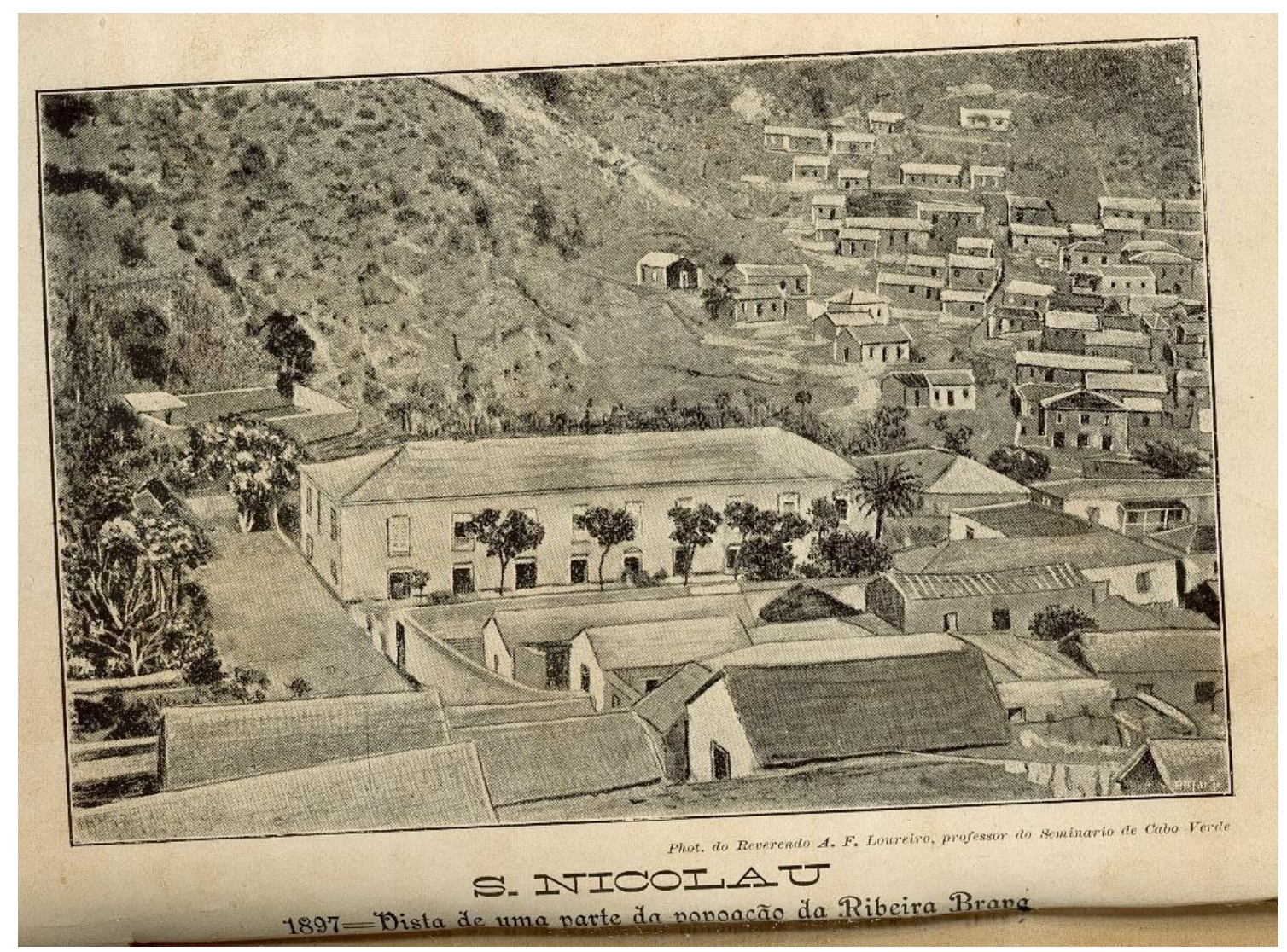

Figura 9: Vista de um povoado da Ribeira Grande - São Nicolau

Fonte: FOTOLOG: imagens de Cabo Verde

Segundo Quinquin (2007), a ilha ficou historicamente famosa "porque foi precisamente nas suas águas que navegaram os navios da armada de Pedro Álvares Cabral em viagem para o famoso e épico descobrimento do grande Brasil".

De acordo com o autor, Cabral fazia parte de uma tradicional e abastada família portuguesa. Nasceu possivelmente em 1467, no Castelo de Belmonte, em Beira Baixa. Naquela época, o comércio terrestre de Portugal passava por um momento difícil, o que fez com que o rei acreditasse que a única solução fosse o mar. Entretanto, para realizar tal empreitada, teria, primeiramente, que vencer o medo que dominava os navegantes, que acreditavam em terríveis monstros que habitavam o oceano. Assim, poderiam alcançar as Índias e comercializar diretamente os produtos muito valorizados na época, 
como especiarias e tecidos finos. Em março de 1500, o rei de Portugal, D. Manuel I, deu a Cabral a missão de liderar uma segunda expedição às Índias (a primeira fora realizada por Vasco da Gama em 1498). Desta vez seria uma grande esquadra, composta por 13 navios e mais de mil homens. Porém, Cabral acabou se desviando de seu caminho, e, em 22 de abril avistou a nova terra, chamada primeiramente de Monte Pascoal, nas costas da Bahia. Nesse desvio de rota, provavelmente Cabral teria se dado a passagem da esquadra por São Nicolau, a qual se refere Quinquin (2007).

Ainda segundo o autor, São Nicolau foi uma importante colônia portuguesa, visto que foi a primeira ilha de Cabo Verde a ter o ensino superior Liceu. O SeminárioLiceu de São Nicolau, que praticamente introduziu o ensino em Cabo Verde, foi criado pelo Decreto- Lei de 3 de Setembro de 1866, e extinto pela Lei no 701 de 13 de Junho de $1917^{16}$. O seminário-Liceu surgiu primordialmente para suprir as necessidades dos sacerdotes visando à catequização em Cabo Verde e também em outras colônias africanas, mas acabou por contribuir para a melhoria do arquipélago visto que a educação passou a ocupar grande parcela da preocupação do povo cabo-verdiano.

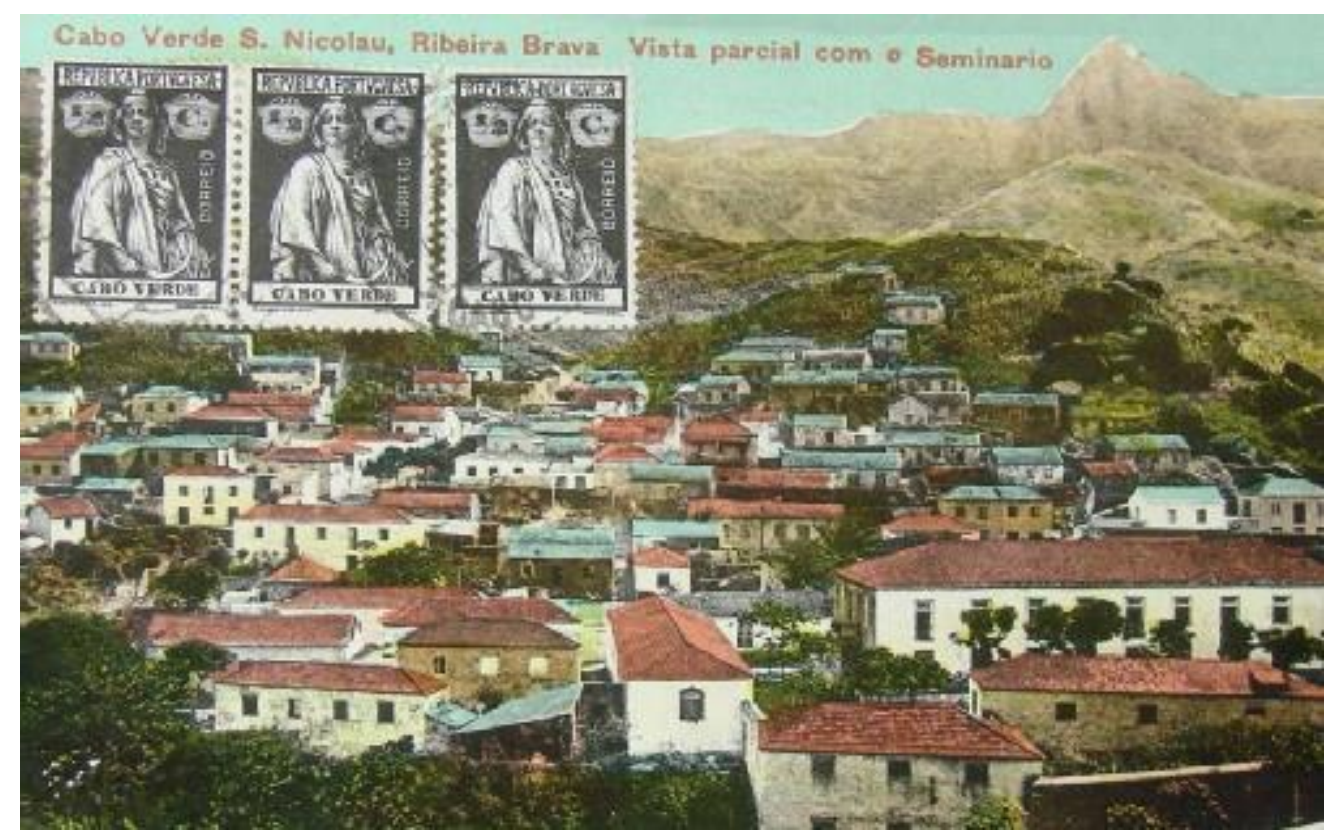

Figura 10: Seminário Liceu de São Nicolau

Fonte: FOTOLOG: imagens de Cabo Verde

\footnotetext{
${ }^{16}$ Baltazar Soares Neves. 2008. O Seminário - Liceu de S. Nicolau - contributo para a história do ensino em Cabo Verde. Porto. CEAUP.
} 


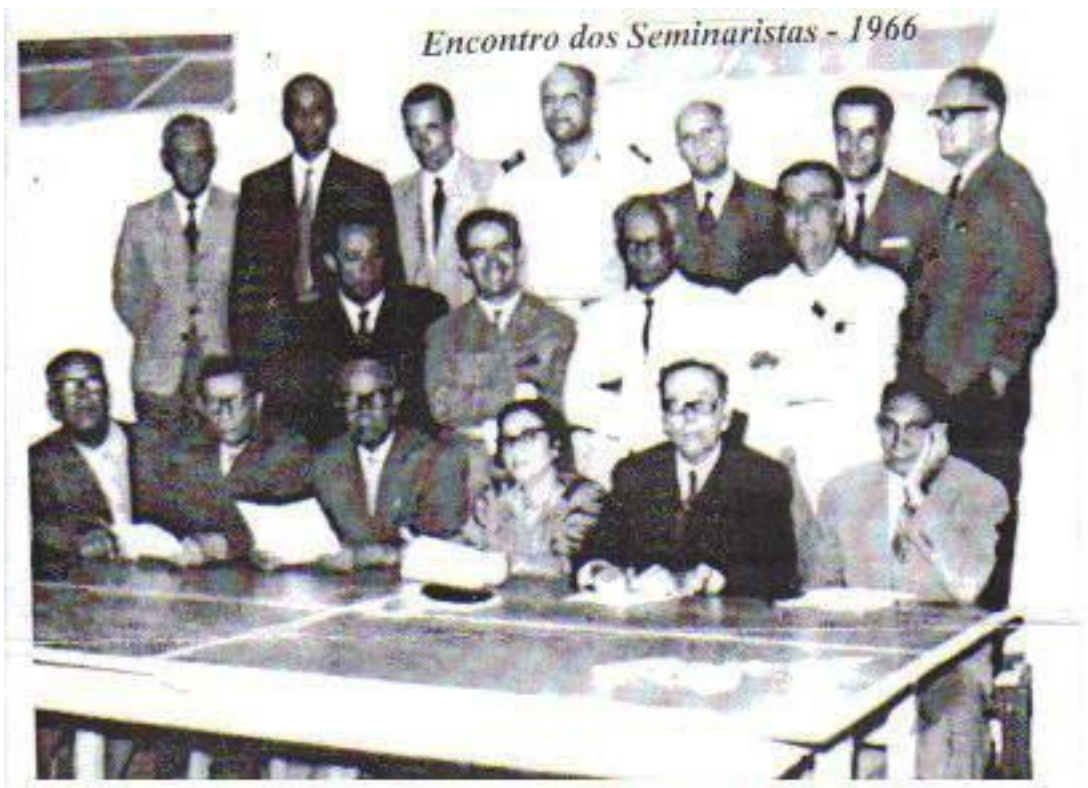

Em cima: Jose Mascarenhas, Pedro Ramos, Plinio Borges,

Manuuel Lopes dos Santos, Antonio Mascarenhas, Olavo Moniz e J. Ramos.

No meio: Jose Tomas, Tuta Melo, Nho Baltas e Juloca Feijoo.

Em baixo: Joao Rocheteau, Teodolo Brito, Djo fei, Irene Almada, (...) e Joao Lopes.

Figura 11: Encontro de ex-seminaristas do Liceu

Fonte: FOTOLOG: imagens de Cabo Verde

Como todas as outras ilhas do arquipélago, São Nicolau também foi devastada por fomes e doenças, como as de 1720, 1735 e 1773. De acordo com a história, quase metade da população perdeu a vida durante esses períodos.

Quinquin (2007), citando o livro "Viagem pela história das ilhas de Cabo Verde" do escritor cabo-verdiano Germano Almeida, argumenta que o número de habitantes da ilha era 6372 no ano de 1860, 6950 em 1878 e 7500 no ano de 1880. Porém, cerca de um terço da população foi exterminada pela fome e pelas doenças que assolaram a região. Assim, em meio às dificuldades, secas e fome, inicia-se o processo de independência das ilhas.

A luta pela independência dos povos coloniais "teve como base o princípio da autodeterminação, entendida como o direito de um grupo humano (definido por características próprias, de escolher, livremente, o seu próprio destino, através da designação do seu estatuto político)” - Monteiro Fernandes (2007). 
Após a II Guerra Mundial e com a criação da ONU (Organização das Nações Unidas) gerou-se uma época anti-colonialismo. No decorrer das décadas de 50 e 60 foram várias as tentativas a favor da descolonização.

Em 1955 um fato importante apoiou a causa da descolonização: a Conferência de Bandung (MONTEIRO FERNANDES, 2007). A conferência de Bandung foi convocada por cinco países asiáticos: Birmânia, Ceilão, Índia, Indonésia e Paquistão, e tinha o objetivo de "estudar os problemas que se punha à soberania nacional, como o racismo e o colonialismo. Representava também a solidariedade das nações asiáticas para com os movimentos emancipalistas de África” (MONTEIRO FERNANDES, 2007). Essa conferência se tornou um fato histórico justamente por ser composta por países com passado colonial. Ao todo foram vinte e nove países recém-independentes, todos apoiando a "causa da liberdade dos povos submetidos a um jugo estrangeiro", pedindo independência aos povos subjugados. A intenção era erradicar o colonialismo na África (MONTEIRO FERNANDES, 2007).

No que se refere a Cabo Verde, desde o início do povoamento das ilhas, surgiram vários tipos de resistência à dominação colonial. As mais significativas ocorreram após a independência do Brasil (MARTINS, 2009: 42-43), tais como a revolta na Ribeira dos Engenhos, em 1822, na qual os camponeses se rebelaram contra a colonização e a revolta dos escravos e jornaleiros da ilha do Sal, em 1836, entre outras.

Assim, com a população caboverdiana gritando por liberdade e autonomia, em setembro de 1956 foi criado oficialmente o partido PAIGC (Partido Africano da Independência da Guiné e de Cabo Verde) por cabo-verdianos e guineenses (FERREIRA, 1999: 27).

Paralelamente, diversos protestos em toda África começaram a ganhar peso, e Portugal passou a sofrer muita pressão internacional para que abrisse mão de suas colônias, mas, ainda assim, não mostrou disposição para reconhecer a autonomia de suas colônias.

Nesse ínterim, além do PAIGC, outros partidos surgiram na luta pela independência das colônias: o FRELIMO (Frente de Libertação de Moçambique), MPLA (Movimento de Libertação de Angola), UNITA (União Nacional para Independência Total de Angola) e o MLSTP (Movimento de Libertação de São Tomé e Príncipe). 
Por fim, após muitas disputas e sangue derramado, Cabo Verde se tornou independente em 5 de julho de 1975 e Aristides Pereira foi eleito o presidente da República. Porém, diferente do que se podia imaginar, a independência não trouxe a tão desejada prosperidade aos cabo-verdianos, fato que fez com que muitos jovens abandonassem as ilhas.

A independência não foi bem vista por todos os habitantes das ilhas, muitos ainda acreditavam que o país ganharia mais se continuasse sendo território português. Alguns acreditavam que o país poderia ser um território autônomo, porém, ainda com vínculos com Portugal.

A língua portuguesa, mesmo após a independência, ainda continuou sendo a língua oficial do país. Era o português que era ensinado nas escolas, fato que complicava a vida das crianças, visto que em seus lares, o crioulo, além de ser a língua materna de cada um, era a língua com a qual tinham contato. Tal fato descontentava os cabo-verdianos, visto que, o crioulo falado nas ilhas representava a identidade nacional da população. Desse modo, no próximo capítulo, abordaremos a formação dos crioulos de modo geral, a formação do cabo-verdiano, bem como a atual situação linguística do país.

\subsection{Síntese do Capítulo}

Nesse capítulo abordamos o arquipélago de Cabo Verde, traçando um panorama histórico desde o período da chegada dos portugueses às ilhas, até o momento da colonização da Ilha de São Nicolau. Nesse enfoque, além de falarmos sobre aspectos históricos, falamos também, ainda que de modo sucinto, um pouco da geografia e de aspectos físicos e climáticos das ilhas.

Esses fatores dificultaram/dificultam a vida dos cabo-verdianos, que sofreram/sofrem com longos períodos de estiagens, algumas das quais mataram muitos indivíduos. Tais dificuldades acabaram por gerar a diáspora cabo-verdiana, que é tão intensa, que o número de cabo-verdianos fora do país é superior aos que habitam no arquipélago.

Em seguida, falamos sucintamente a respeito da importância histórica da ilha de São Nicolau, pois, segundo fontes como Quinquin (2007), foi “precisamente nas suas aguas que navegaram os navios da armada de Pedro Alvares Cabral em viagem para o famoso e épico descobrimento do grande Brasil”. Além disso, foi em São Nicolau que 
surgiu o primeiro Seminário-Liceu, que acabou por institucionalizar o ensino em Cabo Verde.

Finalmente, traçamos um breve panorama a respeito das lutas em favor da independência, e da importância que a língua que ali se formou por ocasião da colonização, para a firmação da identidade do homem cabo-verdiano. 


\section{CAPÍTULO 2}

\section{O CABO-VERDIANO E A VARIEDADE DE SÃO NICOLAU - CONSIDERAÇÕES GERAIS}

\subsection{Introdução}

Como já apresentado na Introdução Geral, as Grandes Navegações, iniciadas no século XV, e os consequentes contatos no que se passou a chamar "Novo Mundo" marcaram o surgimento de línguas denominadas crioulas. A expansão marítima europeia, liderada pelos portugueses, iniciou o tráfico negreiro na costa oeste africana, fazendo com que um grande número de indivíduos, falantes de diversas línguas, vivesse uma situação de multilinguismo possivelmente nunca antes atestada. Segundo Boxer (2008: 15), é preciso que tenhamos em mente que, antes dos descobrimentos iniciados pelos portugueses e pelos espanhóis, a dispersão e o isolamento dos vários ramos das sociedades e línguas humanas eram a regra.

Segundo Arends (1994: 15-17), tomando por base Bickerton (1988), o panorama sócio-histórico da formação das línguas crioulas, dá-se a partir de três tipos: (i) crioulos de plantação: crioulos formados a partir de um grande número de escravos retirados de seu ambiente de origem, utilizados como mão-de-obra na atividade agroexportadora denominada plantation, como ocorreu no Haiti, Jamaica, Guiana, Suriname, São Tomé, Ano Bom e Havaí; (ii) crioulo de quilombo: crioulos formados por um agrupamento de escravos fugidos, como é o caso do saramacan (falado no Suriname); (iii) crioulo de fortaleza: crioulos formados em situações nas quais as populações dominadas teriam se mantido no local de origem, mantendo o uso da língua nativa durante o processo de crioulização, como é o caso do principense falado na Ilha de Ano Bom (São Tomé e Príncipe).

O crioulo de Cabo Verde pode ser classificado como um crioulo do tipo "fortaleza". Dadas as questões climáticas, como apontado no capítulo 1, não foi possível o estabelecimento da agricultura colonial nas ilhas. Logo, o que se estabeleceu foi uma situação de "entreposto comercial" entre a(s) ilha(s) e o comércio marítimo da Colônia.

No que diz respeito à formação de línguas crioulas, podemos citar as hipóteses abruptas e não abruptas. Segundo as teorias abruptas, uma língua crioula teria se formado entre 100 e um pouco mais que 100 anos. O crioulo cabo-verdiano se insere na teoria abrupta de formação, pois foi na segunda metade do século XV que os 
marinheiros portugueses desembarcaram nas ilhas de Cabo Verde. Ver Veiga (2002: 5). Segundo esse autor (op. cit.), as terras encontradas não tinham condições propícias à agricultura e os recursos do subsolo eram bastante precários, porém "desde a primeira hora pensou-se que a situação geográfica das ilhas (na encruzilhada de três continentes - Europa, África e as Américas) era favorável ao comércio escravocrata."

Os negros eram capturados na Costa Ocidental Africana (cada qual com sua língua e cultura) e em seguida mandados para Santiago (cidade da Ribeira Grande) para serem ladinizados, ou seja, para aprenderem os princípios básicos da língua e religião portuguesas, e depois exportados tanto para a Europa quanto para a América do Sul.

As línguas crioulas das áreas geográficas da Alta Guiné, Golfo da Guiné e ilhas do Caribe, podem, portanto, em seus aspectos sócio-históricos terem a seguinte classificação: (A) Crioulos da Alta Guiné: (i) Cabo Verde (crioulo de fortaleza), (ii) Guiné Bissau (crioulo de fortaleza). De acordo com Kihm (1994: 4), a visão tradicional, é que a crioulização primeiro se deu em Cabo Verde e depois teria sido transplantado para o continente pelos lançados ${ }^{17}$. Jacobs (2010: 300)18, apresentando fatos históricos e linguísticos, corrobora a proposta de que o subgrupo da Alta Guiné teria se originado na ilha de Santiago, em Cabo Verde. De acordo com o autor, um protocrioulo teria se formado primeiro em Santiago, sendo levado em seguida para Cacheu, de onde provavelmente tenha se espalhado para Ziguinchor, Geba e Bissau. (B) Crioulos do Golfo da Guiné: (i) São Tomé e Príncipe: principense (crioulo de plantação), sãotomeense (crioulo de plantação), angolar (crioulo 'quilombo'); (ii) Guiné Equatorial: anoboense (crioulo de plantação). (C) Crioulos das Ilhas ABC (Aruba, Curaçao e Bonaire): papiamentu (crioulo de plantação). Jacobs (2010: 330) aponta, ainda, evidências linguísticas e históricas indicando que o papiamentu teria se originado a partir do mesmo protocrioulo formado em Santiago. De acordo com o autor, esse protocrioulo foi transplantado para as ilhas holandesas através de judeus sefardistas e seus escravos.

Neste capítulo tecemos considerações gerais sobre as línguas crioulas, tomando como exemplo o cabo-verdiano na variedade de Barlavento.

\footnotetext{
${ }^{17} \mathrm{O}$ termo 'lançados' passou a ser designado, entre historiadores e crioulistas, a um tipo aventureiro no mundo colonial que se tornaria personagem principal no processo de colonização da África em geral. Couto \& Embaló (2010: 20) refere-se à importância histórica de João Fernandes entre os africanos por ser possivelmente o primeiro português a conviver pacificamente com africanos negros e mouros. Logo, teria sido ele um dos primeiros 'lançados' da história.

${ }^{18}$ Jacobs (2010) subseção 4.1
} 


\subsection{O Crioulo de modo geral e o cabo-verdiano}

No capítulo 1, introduzimos o arquipélago de Cabo Verde, o surgimento do povo cabo-verdiano e falamos rapidamente sobre o crioulo cabo-verdiano e sua importância no tocante à questão de identidade do povo do arquipélago. Nesta seção buscamos: (i) discutir a formação das línguas crioulas, abordando algumas teorias acerca de seu surgimento; (ii) apontar uma conceituação atual sobre pidgin, crioulo e pidgincrioulo; (iii) apresentar aspectos da língua cabo-verdiana não como um todo mas por meio de significativas diferenças dessa língua se comparada com um sistema não crioulo, como o do português, por exemplo; (iv) situar, dentro do multilinguismo existente nas ilhas de Cabo Verde, o intenso debate entre diglossia e bilinguismo.

\subsubsection{Hipóteses sobre a gêneses das línguas crioulas - algumas teorias}

A gêneses das línguas crioulas é alvo de ampla discussão na literatura, que vem sendo abordada por meio de hipóteses conhecidas como: (i) teorias do 'input' europeu' (ver: BESTEN, MUYSKEN \& SMITH, 1994); (ii) teorias do 'input' não europeu (ver: ARENDS, KOUWENBERG \& SMITH, 1994); (iii) teorias gradualistas (ver: ARENDS \& BRUYN, 1994); (iv) teorias universalistas (ver: MUYSKEN \& VEENSTRA, 1994).

O crioulo cabo-verdiano, centro de nossa análise, vem sendo estudado dentro de teorias do 'input' europeu, não europeu e de teorias universalistas.

Os estudos sobre línguas crioulas, especialmente as de base portuguesa, se iniciaram a partir do século XIX. No entanto, questões acerca da gêneses dessas línguas são amplamente discutidas na literatura, como já apontamos acima.

Delgado (2009: 62) destaca duas grandes posições teóricas no estudo dos crioulos: a 'dialetológica' e a 'substratista'. No entanto, chamamos a atenção do leitor para as outras duas abordagens teóricas: a 'universalista' e 'gradualista'. Diferentemente de Delgado (2009: 62), se tomarmos a gêneses do cabo-verdiano como enfoque de análise, a única abordagem que não caberia seria a 'gradualista'. Segundo seus proponentes, ao contrário da "teorização abrupta"19, o modelo gradualista afirma que a crioulização, em um grande número de casos, como o sranan, o haitiano e o jamaicano, não foi

\footnotetext{
${ }^{19} \mathrm{O}$ cabo-verdiano insere-se em teorias de formação abrupta, pois documentações nos permitem afirmar que em menos de cem anos ele já havia sido formado.
} 
instantânea, mas passou por um processo gradual, estendido por um grande número de gerações de falantes - ver: (McWORTHER, 1992), (DeGRAFF, 2001), entre outros.

A posição dialetológica considera os crioulos como sendo simplificações de línguas europeias - ver, por exemplo, teorias do 'input' europeu' citadas acima. A posição substratista defende que as línguas crioulas são produtos de hibridismo linguístico, em que novas espécies resultam do cruzamento de outras línguas (DELGADO, 2009: 62) - ver, por exemplo, teorias do 'input' não europeu citadas acima.

Atente o leitor para dois importantes autores do sec. XIX: Adolfo Coelho e Hugo Schuchardt. Adolfo Coelho será o primeiro autor a tratar das línguas crioulas e o faz dentro de uma perspectiva dialetológica - ver Coelho (1881). O filólogo alemão Schuchardt (1882), no mesmo período, troca intensas correspondências com Coelho sobre essas línguas, também vistas por ele como "dialetos", como se pode ver no excerto abaixo ${ }^{20}$ :

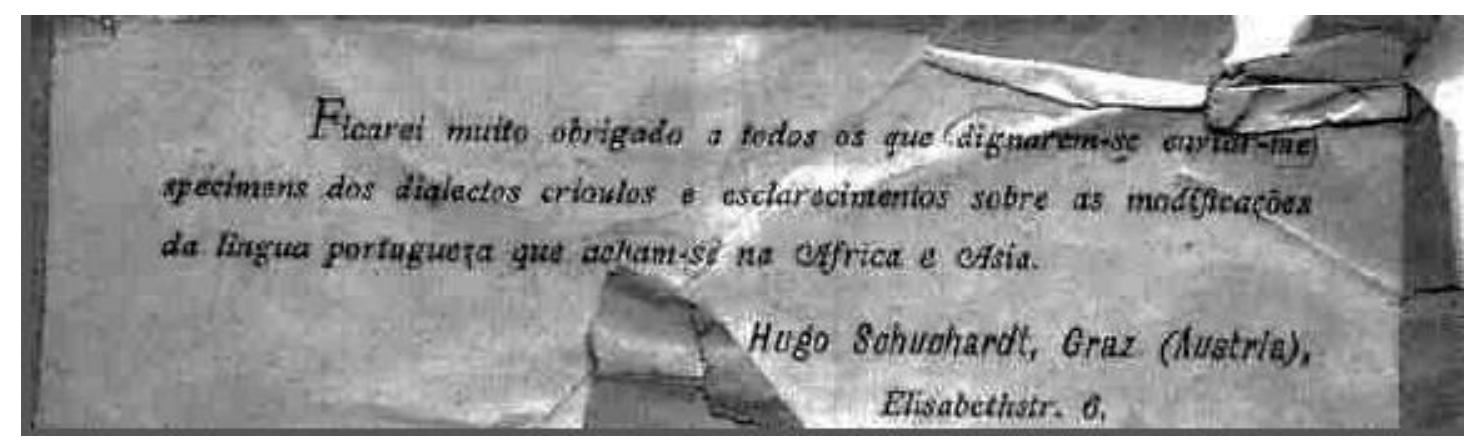

Figura 12: Trecho da carta trocada entre Schuchardt e Coelho a respeito de dialetos crioulos do português existentes na África e Ásia.

Fonte: Paixão de Souza (2012)

Coelho, em uma conferência proferida em 16 de fevereiro de 1878, chama a atenção para "fórmas dialectaes particulares que algumas linguas europêas $e$ particularmente o francez, o hespanhol e o portuguez, tinham tomado nas colonias e conquistas da Africa, Asia e América" (COELHO, 1881: 3). O autor aponta uma série desses dialetos. Abaixo enfocamos os dialetos portugueses citados por Coelho (1881: 4):

\footnotetext{
${ }^{20}$ Retirado de Paixão de Souza (2012).
} 
- Dialetos crioulos portugueses: crioulo da ilha de Santo Antão (Cabo Verde), que segudo Coelho "é fallado principalmente pela população de côr e pelas creanças que o aprendem com as creadas e amas negras" (COELHO,1881: 4); crioulo de São Tomé; crioulo da Ilha de Santiago (Cabo Verde); crioulo da Guiné portuguesa, português do Brasil; dialeto português do Ceilão ou indoportuguês; dialeto português de Malaca; dialeto macaista.

Ainda dentro da posição de cunho dialetológico, e que podemos inserir como de 'imput europeu', ressaltamos a teoria monogenética. A teoria monogenética defende uma origem única para pidgins e crioulos. Segundo seus proponentes, há basicamente duas versões para essa teoria: a primeira diz que todos os crioulos derivam de um pidgin de base lexical portuguesa do oeste africano; a segunda versão afirma que os crioulos surgiram a partir de uma Língua Franca do Mediterrâneo - o sabir -, como esquematizamos abaixo por meio de dois quadros:

De acordo com Besten, Muysken \& Smith (1994: 88), a monogênese, muito em alta nos anos 60 e 70, formulada por Taylor (1961) e Thompson (1961), assumia que esse pidgin 'ancestral', aprendido pelos escravos e navegadores no processo da expansão ultramarina, teria sido o precursor dos vários crioulos de base europeia surgidos na ocasião. Para explicar a formação de crioulos de diferentes bases, hipotetizou-se que crioulos franceses, ingleses e outros derivaram do WAPP por processo de relexificação ${ }^{21}$.

Quadro 3: Versão 1 da Monogêneses: Monogêneses e o Pidgin-Português do Oeste Africano (WAPP) ${ }^{22}$

Fonte: Besten, Muysken \& Smith (1994: 88)

Segundo essa teoria, o WAPP, do qual todos os crioulos do Atlântico teriam se
derivado, surgiu de uma Língua Franca falada no Mediterrâneo. Essa língua é
conhecida na literatura como sabir. Para detalhes, ver Holm (1989: 607).

Quadro 4: Versão 2 da Monogêneses: Monogêneses e a Língua Franca

Fonte: Besten, Muysken \& Smith (1994: 88)

\footnotetext{
${ }^{21}$ Chamamos a atenção do leitor para o fato de que a "relexificação" aqui apontada não se trata da "Hipótese de Relexificação", amplamente discutida na literatura, no escopo da teoria substratista - ver Lefebvre (1986).

${ }^{22}$ Seguimos a sigla em inglês de West African Pidgin Portuguese - WAPP (BESTEN, MUYSKEN \& SMITH (1994: 88).
} 
Dentro das teorias que enfocam o 'input' não europeu, podemos enquadrar as teorias substratistas que serão significativas para o estudo do cabo-verdiano. Segundo Arends, Kouwenberg \& Smith (1994):

O termo 'substrato' tem sua origem na linguística Histórica do século XIX e na geografia dialetal. Esse termo se refere a línguas ou dialetos de grupos de não prestígio em situação de contato. O Gaulês, uma língua céltica já extinta, falada na França, foi assumida, por exemplo, como substrato do Latime que se desenvolveu durante o domínio Romano. Similarmente a língua do grupo com maior prestígio é denominada 'superstrato' ou 'superstratum'. Finalmente, quando duas línguas ditas de igual prestígio estão em contato, refere-se a elas como línguas do 'adstrato'. Nos estudos em línguas crioulas, porém, o termo 'adstrato' é frequentemente usado para se referir a línguas que estiveram envolvidas na gêneses de um crioulo, sem, contudo, pertencer ou ao substrato ou ao superstrato. $[\ldots]^{23}$

Dentro das hipóteses substratistas na gêneses das línguas crioulas - ou seja, línguas de menor prestígio, mas que deixam contribuições no estrato - um grupo particular de línguas do oeste africano são comumente referendadas: as línguas do grupo Kwa da grande família nigero-congolesa, principalmente representadas nos atuais países de Gana, Togo e Benin - ver (ARENDS, KOUWENBERG \& SMITH, 1994: 99).

Outro conjunto de propostas importante para a discussão da gêneses das línguas crioulas é conhecido como "abordagens universalistas" - que, de modo geral, podem ser referendadas como hipóteses desde Coelho (1881: 68): A transformação da linguagem em virtude da alteração fonética é um fenômeno de base physiologica; a formação dos dialectos creolos é no que tem de essencial um fenômeno psychologico. Desse modo, o autor, por meio dessa clássica citação sobre os crioulos românicos e dialetos indoportugueses, atribuiu, ao processo de formação desses, influências das ações de leis fisiológicas e psicológicas, e não a influências de línguas antecedentes de povos onde esses dialetos são encontrados. Logo, as teorias universalistas parecem já ter se formado em contraposição às teorias substratistas ${ }^{24}$.

Uma das teorias universalistas muito citadas na gêneses dos crioulos é a pertencente à teoria da gramática, tendo como seu precursor Dereck Bickerton - ver Bickerton (1984, 1988). Não nos interessa neste texto enfatizar o chamado "Bioprograma" de Derek Bickerton em seus detalhamentos, os quais, muitos deles, nem

\footnotetext{
${ }^{23}$ Arends, Kouwenberg \& Smith (1994: 99); a tradução é nossa.

${ }^{24}$ Muito com certeza, Adolfo Coelho não tinha a minima intenção de instaurar a hipótese universalista ao afirmar estas palavras, mas ele o fez na intenção de ser anti substratista - ver Muysken \& Veenstra (1994: 121).
} 
mais se discutem hoje em dia. Interessa-nos, no entanto, enfocar a proposta de Bickerton, comparando o pidgin e o crioulo havaiano. Bickerton identifica traços específicos no crioulo havaiano e propõe que esses fizessem parte de qualquer língua crioula. Logo, instaura-se uma abordagem de cunho universalista nos estudos crioulistas na era moderna - e com "roupagem de teoria gerativista".

Enfatizamos, portanto, o programa de estudo da gêneses das línguas crioulas dentro da "gramática universal", já que Bickerton instaura-se dentro de um conjunto de subteorias universalistas denominadas de "universais constitutivas":

Universais constitutivos pertencem ao domínio da teoria da gramática. Um primeiro exemplo pode ser:

[...] Cada língua natural deve pertencer a uma Gramática Universal

(MUYSKEN \& VEENSTRA, 1994: 123, a tradução é nossa)

Ao término desta subseção é importante destacar que alguns estudos centrados em línguas que são referendadas como completamente reestruturadas (línguas crioulas, como o cabo-verdiano) e ainda em parcialmente reestruturadas (português brasileiro, por exemplo) $)^{25}$ vêm atenuando a oposição "teorias universalistas" versus "teorias substratistas" - ver, entre outros, Oliveira (2011); Holm (2012).

Oliveira (2011) enfatiza em sua análise uma abordagem universalista, sem, contudo, negar a importância do substrato. A autora (op cit.) cita Mufwene (1986: 129):

[...] the universalist and substrate hypotheses are not necessarily mutually exclusive $[\ldots]$

\subsubsection{Os conceitos de pidgin, crioulo e pidgincrioulo}

A palavra pidgin, segundo algumas tradições, derivou-se da prosódia da palavra inglesa business (negócio), pronunciada em chinês. Pidgin English era o nome dado ao

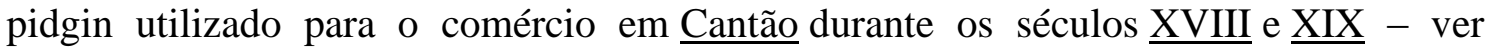
Gómez (2012: 1).

Alguns acadêmicos questionam esta derivação da palavra pidgin e sugerem etimologias alternativas. De acordo com o etnógrafo Gómez (2012: 2), outra derivação foi proposta por Kleinecke (1959): a palavra teria se derivado de 'pidian', termo sulamericano que significa 'gente'. Portanto essa palavra poderia ser a alteração ortográfica de ‘indian’ (índio). Ainda, segundo Gómez, o estudioso Winterstein (1908) propôs que a palavra 'pidgin' teria se originado do hebreu 'pidjom', que significa

\footnotetext{
${ }^{25}$ A terminologia 'línguas reestruturadas' ganhou evidência a partir de Holm (2004).
} 
comércio ou negócio. Porém, nenhuma das propostas acima citadas obteve ampla aceitação no meio acadêmico.

Uma primeira definição de pidgin, no entanto, passa a ser conhecida entre os linguistas: Bakker (1994). A essa definição chamaremos de $1^{\text {a }}$. definição de pidgin, vista no quadro a seguir:

Pidgins são línguas lexicalmente derivadas de outras línguas, mas que são estruturalmente mais simplificadas, especialmente em sua morfologia. Surgem onde pessoas precisam se comunicar, mas não têm uma língua em comum. Pidgins não tem nenhum (ou poucos) falantes como primeira língua; é necessário que sejam estudados; eles têm normas estruturais; são usados por dois ou mais grupos e são, geralmente, ininteligíveis para os falantes da língua da qual seu léxico deriva.

Quadro 5: Primeira definição de pidgin segundo Bakker - tradução nossa ${ }^{26:}$ Fonte: Bakker (1994: 25)

Segundo Bakker (1994: 26), pidgins são sempre línguas simplificadas em relação à língua lexificadora, entretanto nem toda língua simplificada é um pidgin. Logo, para o autor, o termo pidgin não pode ser confundido com broken language. Atualizamos exemplificações de Bakker (1994) para broken language por meio de um possível falante de português brasileiro que estaria "tentando" falar inglês e, dessa forma, imaginando que estivesse falando um inglês fluente, mas, ao contrário, estaria falando uma variedade distante do inglês - falando, portanto, uma "variedade quebrada de inglês" (no entanto, isso não seria um "pidgin").

De acordo com Bakker (1994: 29), é possível que indivíduos de um determinado grupo adotem palavras da língua de outros grupos com quem mantêm contato, desenvolvendo um jargão, com vocabulário bastante reduzido, restrito, para transmitir mensagens. Se o contato continua, o jargão se desenvolve numa língua mais estruturada, que poderá ser chamada de pidgin.

Um ponto para o qual chamamos a atenção com relação à primeira definição de pidgin oferecida por Bakker (1994) acima é que nela está contida a noção de "simplificação morfológica". Logo, a definição de pidgins (e também crioulos), na

\footnotetext{
${ }^{26}$ Pidgins are languages lexically derived from other languages, but wich are structurally simplified, especially in their morphology. They come into being where people need to communicate but do not have a language in common. Pidgins have no (or few) first language speakers, they are the subject of language learning, they have structural norms, they are used by two or more groups, and they are usually unintelligible for speakers of the language from wich the lexicon derives.
} 
versão do quadro 5, é a de línguas que não atestam fenômenos morfológicos como flexão e derivação.

Entretanto, Bakker (2003: 4) refuta o conceito de que pidgins não possuem morfologia flexional, demonstrando ser uma visão equivocada a de que essas línguas sejam línguas "morfologicamente empobrecidas". Seu estudo de um amplo conjunto de variedades aponta para o fato de que os pidgins tendem a ter mais (diferentemente de menos) morfologia flexional, do que os crioulos, o que é uma surpresa. Uma razão para a qual Bakker oferece para esta descoberta é que a série tipológica de línguas que se dão no 'input' dos pidgins, em sua investigação, é muito mais ampla que a série do 'input' de línguas crioulas. Ainda, a 'série' do 'input' das línguas pidgins é morfologicamente mais rica. No caso das línguas crioulas, apesar de muitas dessas línguas não expressarem morfologia flexional, há casos atestados de flexão nominal, verbal, adjetival.

Logo, uma segunda definição de pidgin é apresentada por Bakker (2003), que se baseia em cinco características:

1. Pidgin são tipicamente línguas não maternas;

2. o pidgin nunca é a única língua de um dos grupos que a fala (pelo menos é a língua de dois grupos étnicos distintos);

3. pidgins têm normas que têm que ser aprendidas. A normatividade exclui os jargões que são estados prévios que precedem os pidgins;

4. em geral, pidgins não são línguas ou falas de uma comunidade ou grupo étnico. São usados para suprir vácuos de comunicação de diferentes grupos;

5. pidgins raramente preenchem a função poética da linguagem.

Quadro 6: Segunda definição de pidgin segundo Bakker

Fonte: Bakker (2003:4, 5); a tradução é nossa.

Bakker (2003:5-9) propõe uma tripartição nos estudos de pidgins e crioulos a fim de isolar propriedades de línguas pidgins. Segundo o autor, somente essa tripartição é capaz de apontar claramente para as diferenças estruturais e sociais que existem entre pidgins e crioulos. Para Bakker (2003: 5), pidgin é uma categoria desviante de pidgincrioulo e crioulo. Logo, enquanto pidgincrioulo e crioulo se aproximam, pidgin se distancia desses dois conceitos. 
Bakker (2003: 5) inicia a seção afirmando que muita atenção tem sido dada às línguas crioulas e que apenas recentemente a noção de pidgin não expandido (pidgin) tornou-se foco de uma pesquisa comparativa - ex. Bakker (1994).

A proposta de pidgincrioulo de Bakker (2003: 8) abarca um número específico de línguas que têm sido tratadas na literatura como pidgins (extendidos) e que, segundo o autor, não são representativos de pidgins. Ex: Tok Pisin (Papua Nova Guiné); West African Pidgin English (pidgin de base inglesa falado no oeste da África).

Bakker (2003: 7) propõe parâmetros sociolinguísticos a fim de diferenciar as três categorias de línguas reestruturadas - apresentadas pelo autor em uma tabela (BAKKER, 2003: 7 - tabela 1) ${ }^{27}$ :

\begin{tabular}{|l|l|l|l|}
\hline & PIDGINS & PIDGINCRIOULOS & CRIOULOS \\
\hline Língua nativa & Não & Não/sim & Sim \\
\hline $\begin{array}{l}\text { Língua geral da comunidade ou } \\
\text { língua oficial }\end{array}$ & Não & Não/sim & Sim \\
\hline $\begin{array}{l}\text { Língua de um grupo étnico ou } \\
\text { político }\end{array}$ & Não & Não & Sim \\
\hline $\begin{array}{l}\text { Os Falantes a têm como única } \\
\text { língua }\end{array}$ & Não & Não/sim & Sim \\
\hline $\begin{array}{l}\text { Usada por pessoas que não têm } \\
\text { outra língua em comum }\end{array}$ & Sim & Sim/não & Não \\
\hline $\begin{array}{l}\text { Usada principalmente como } \\
\text { segunda língua }\end{array}$ & Sim & Sim/não & Não \\
\hline $\begin{array}{l}\text { Função expressiva } \\
\text { Quãadro 7: parão }\end{array}$ & Sim & Sim \\
\hline
\end{tabular}

Quadro 7: parâmetros sociolinguísticos de diferenças entre pidgins, pidgincrioulos e crioulos

Fonte: Bakker (2003: 7, - tabela 1- a tradução é nossa)

Observa-se no quadro em 7 que pidgincrioulos apontam similaridades com pidgins e com crioulos, porém, mais com crioulos.

Importante ressaltar que, segundo Bakker (2003), alguns estudiosos utilizam o termo 'pidgin expandido' para distinguir dos pidgins não expandidos. Porém, Bakker utiliza o termo pidgincrioulos, pois, conforme o próprio autor, o termo pidgin expandido é ambíguo haja vista que pode abranger tanto a expansão estrutural quanto a social. Por outro lado, o autor (op cit.) define pidgincrioulo em termos sociais:

\footnotetext{
${ }^{27}$ Para o autor ' não/sim' significa mais frequentemente 'não' do que 'sim', portanto, 'sim/não' significa mais frequentemente 'sim' do que 'não'.
} 
"aproximadamente como um pidgin com algum falante nativo elou com um papel dominante em uma sociedade" (BAKKER, 2003: 5). Logo, Bakker não propõe meramente uma nova taxonomia, mas fundamenta-se sociolinguisticamente ao distanciar pidgins de crioulos, e ao acrescentar a categoria pidgincrioulo junto a crioulos.

Ao término dessa discussão, pensamos ser importante, ainda, destacar a distinção que se faz na literatura entre línguas crioulas e as chamadas 'misturas bilíngues' e também entre pidgins e koinés, como se atesta em Oliveira \& Holm (2011: 30):

De acordo com Holm (2000, 2004), línguas crioulas diferem de outras linguas completamente reestruturadas como as 'misturas bilingues' (também chamadas de 'intertwined languages'), por exemplo, que se desenvolveram fora de um 'continuum pidgin' (ou pré-pidgin)[...]. Na pidginização, os falantes de um superstrato (ou língua fonte do léxico) - por definição, o grupo mais 'poderoso'política e socialmente - cooperam com falantes de línguas do substrato - sem influência social - para criarem uma língua do tipo emergencial. Isto ocorre a fim de que preencham uma necessidade de comunicação com propósitos especificos (ex.: comércio). Esta 'cooperação' ocorre pela ausência de uma língua em comum. Logo, os falantes das línguas do substrato têm a tarefa, nesse processo, de aprender o léxico do superstrato. No entanto, a fim de facilitar a compreensão, os falantes da língua do superstrato 'imitam' a forma como os falantes das línguas do substrato falam sua língua (o superstrato). Assim, o pidgin resultante, embora possua algumas normas, não é a língua nativa de nenhum dos grupos que a falam. Devemos ainda dizer que: (i) as línguas, nesse tipo de contato, não são 'proximamente relacionadas', pois se assim o fossem o resultado seria uma koiné e não um pidgin; (ii) a distância social entre os falantes da língua do superstrato e as do substrato é mantida durante os processos de comunicação, pois de outro modo, esses falantes poderiam afinal aprender, com naturalidade e certa perfeição, a língua um do outro.

A título de exemplificação, o que poderíamos chamar de koiné, diferente de uma língua pidgin, seriam as chamadas 'Línguas Gerais', que surgiram na América Latina no século XVI e XVII em condições especiais de contato entre europeus e povos indígenas - ver, entre outros, Rodrigues (1996); Argolo (2013).

\subsection{Um panorama sociolinguístico de Cabo Verde}

De acordo com Veiga (2002: 12), entre os séculos XV e XVIII, deu-se o período de formação e autonomização do cabo-verdiano, em um contexto pluriétnico e plurilinguístico. No entanto, a língua portuguesa, nesse período, ainda não tinha 
instrumentos para que pudesse se afirmar e se difundir, e o cabo-verdiano, já formado, era a língua usada até mesmo pelos brancos.

No século XIX a situação começou a mudar com a criação do Seminário-Liceu de São Nicolau, o que fez com que o ensino da língua portuguesa se desenvolvesse significativamente em Cabo Verde. Neste período começaram a surgir os puristas da língua portuguesa e os ataques contra o cabo-verdiano. O primeiro passo foi proibi-lo na administração e em estabelecimentos de ensino. Tal situação prejudicou não apenas o prestígio como também o desenvolvimento da língua cabo- verdiana - (VEIGA, 2001: 13).

Desse modo, no decorrer do século XIX, muitas vozes se ergueram contra o crioulo cabo-verdiano, que passou a ser chamado de gíria ridícula, composto monstruoso e também de língua que não favorece a ideia unitária do Império, e por isso mesmo devia ser combatido (VEIGA, 2002: 14).

Entretanto, foi neste mesmo século que algumas vozes começaram a se unir em favorecimento à língua como Brito (1888). Em 1903, Cônego Teixeira publicou a "Cartilha Normal Portuguesa", que apesar do nome, ensinava os rudimentos do caboverdiano. Pedro Cardoso foi um professor que publicou, em 1932, o livro Folclore Caboverdeano a fim de preservar a tradição cultural do arquipélago, e também defender publicamente a língua materna de seu povo.

Eugênio Tavares foi um dos maiores poetas da crioulidade. Escreveu o livro Morna - Cantigas Crioulas, editado em 1932, que é um marco no que se refere à alma crioula. Ao usar a crioulo como língua literária, o autor acaba com os argumentos de quem alegava que o crioulo não tinha regras nem gramática e muito menos ainda dignidade literária (VEIGA: 2002: 20).

As letras, as artes e a tradição cabo-verdiana muito contribuíram para a elevação da língua crioula a símbolo da identidade cabo-verdiana. Como exemplo, podemos citar a música que "tem sido o grande laboratório e o grande cenário onde a afirmação e a dignificação do CCV aconteceram, têm acontecido”(VEIGA, 2002: 25).

Segundo o autor, através da música, o povo cabo-verdiano se diverte, ensina, critica e exorta, e tudo isso é possível devido a língua cabo-verdiana, pois todos, desde o mais rico até o mais pobre, estão inseridos no mundo da música e consequentemente, no da língua cabo-verdiana. Desse modo, pode-se afirmar que, 
como símbolo da resistência e da reconstrução nacional, a música caboverdiana, em estreita colaboração com a língua crioula que the dá corpo, lutou contra a escravatura, enfrentou a dureza do regime colonial, criticou e aconselhou o 'poder' na primeira e na segunda República, mobilizou e desmobilizou eleitores, divertiu crianças, jovens e adultos, consolou e animou os tristes e os que sofrem, ligou e aproximou os emigrantes à terra que os viu nascer ou ao torrão dos antepassados, deu pão a muita gente que dela fez campo de sementeira ou ceara para a colheita.

(VEIGA, 2002:26)

A música cabo-verdiana fez com que a língua e as tradições de Cabo Verde atravessassem as fronteiras e chegassem a outros mundos e em outras culturas, e como uma das grandes vozes de Cabo Verde, podemos citar Cesária Évora, cujas letras das músicas transpassaram continentes.

Assim, Com todas essas vozes se erguendo em favor do cabo-verdiano e, com a língua portuguesa sendo ensinada nas escolas, os cabo-verdianos, ao sentirem a necessidade de fixarem por escrito sua língua, tiveram como referência o alfabeto que conheciam melhor: o da língua portuguesa. Assim sendo, de acordo com Veiga (2002: 43) "[...]o alfabeto português foi pura e simplesmente transplantado para a escrita do CCV, sem prévio estudo fonético-fonológico dessa última língua”.

No ano de 1888, foi feito, por António de Paula Brito, a primeira proposta que se tem notícia de um alfabeto cabo-verdiano. A proposta, devido o princípio fonológico utilizado, foi muito original e funcional para a época. $\mathrm{O}$ alfabeto idealizado era composto por 21 letras e 4 dígrafos.

Em 1979, quatro anos após a independência de Cabo Verde, foi organizado o $1^{\circ}$ Colóquio Internacional sobre a Valorização do Crioulo cabo-verdiano: o Colóquio Linguístico de Mindelo. Nesse encontro surgiu a primeira proposta para o modelo de alfabeto fonético-fonológico para a escrita da língua cabo-verdiana. A orientação que a UNESCO dava para a transcrição das línguas, ou seja, o uso do IPA (Alfabeto Fonético Internacional) e do IAI (Alfabeto do Instituto Africano Internacional), influenciaram, de modo fundamental a proposta subscrita pelos participantes do Colóquio de Mindelo (VEIGA, 2002: 46).

Em 1993, o Departamento de Linguística do então Instituto Nacional da Cultura (INAC) propôs que fosse criado o Grupo de Padronização formado por linguistas, professores e escritores. Personalidades como Manuel Veiga, Dulce Duarte, Eduardo Cardoso, entre outros, trabalharam durante seis meses apresentando a proposta do 
Alfabeto Unificado para a Escrita do cabo-verdiano - ALUPEC -, cuja "particularidade fundamental consiste na harmonização dos dois modelos de alfabeto, o de base etimológica (com legitimidade histórica) e o de base fonológica com legitimidade econômica, sistemática e funcional” (VEIGA, 2002: 48).

O ALUPEC é de base latina e compõe-se de vinte e três letras e quatro dígrafos, com a representação maiúscula e minúscula, na seguinte ordem de apresentação, conforme apresentado no DECRETO-LEI nº 67/1998:

\section{A B D DJ E F G H I J K L LH M N NH O P R S T TX U V X Z}

\section{a b d dj e f g h i j k l lh m nh op r s t txu v x z}

A situação sociolinguística de Cabo Verde é bastante complexa. O sentimento depreciativo que se assumiu com relação ao cabo-verdiano continuou após o período pós-independência - 05 de julho de 1975 - e prevalece até os dias atuais, propiciando assim, o surgimento da situação sociolinguística conhecida como diglossia ${ }^{28}-$ as duas línguas faladas no arquipélago, o cabo-verdiano e o português, desempenham papeis distintos e demarcados na sociedade cabo-verdiana, não sendo 'permitido' socialmente que uma ocupe o lugar reservada à outra (LOPES, a sair: 2.2) ${ }^{29}$.

No entanto, as questões linguísticas de Cabo Verde, que perpassam os conflitos locais, políticos e sociais do país, vêm suscitando o questionamento acerca da situação sociolinguística do país: seria Cabo Verde um caso de diglossia ou de bilinguismo?

Para Lopes, A. (2011), a situação em Cabo Verde é a de bilinguismo.

Para Lopes (a sair), o termo diglossia é usado como descritivo da realidade caboverdiana, no sentido de que a diglossia não seja a situação ideal em termos de política linguística. Logo, Lopes (a sair) pensa ser importante debater tais questões, revisitando os conceitos de diglossia e bilinguismo. Para o autor (op cit: 2.2.), os dois termos não são auto-exclusivos, antes pelo contrário. A situação de diglossia pressupõe a existência do bilinguismo como requisito mínimo. Lopes (op cit.) afirma que, um díglosso, por definição e etimologia, é um bilíngue, ou seja, alguém que fala duas línguas. Baseandose ainda nos mais modernos conceitos de bilinguismo aceitos pela comunidade

\footnotetext{
28 Segundo Ferguson (1959: 325): "Diglossia é uma situação relativamente estável da língua, em que, além dos dialetos primários da língua (que podem incluir um padrão ou padrões regionais), há um muito divergente, altamente codificada (frequentemente gramaticalmente mais complexa) variedade superposta, o veículo de um grande e respeitado corpo de literatura escrita, quer de um período anterior ou em outra comunidade de fala, o que é aprendido em grande parte pela educação formal e é usado para a maior parte dos fins escritos, formais e falado, mas não é usado por nenhum segmento da comunidade para uma conversa normal".

${ }^{29}$ Outros autores que assumem Cabo Verde como uma situação de diglossia são: Duarte (1977), Lopes (2011), Veiga (2004), (2009).
} 
científica, Lopes (a sair: 2.2) entende a sociedade cabo-verdiana como uma comunidade de fala com diversos níveis de bilinguismo:

Cabo Verde é uma nação diglóssica (por questões de ordem política e não linguística), mas os caboverdeanos são falantes bilíngues tendo o CCV como a língua materna e com diferentes graus de proficiências no PCV. O entendimento da realidade sociocomunicativa de Cabo Verde, como uma comunidade com indivíduos bilíngues, pode encontrar embasamento teórico no Quadro Europeu Comum de Referência para Línguas (QECR), de 2001 que define seis níveis comuns de referência (A1 a C2) para três grandes tipos de utilizador: o elementar, o independente e o proficiente. Os seis níveis estão definidos para as várias subcompetências em que se desdobra a competência comunicativa [...]

A seguir apresentamos figura que demonstra a situação de convivência entre as duas línguas em Cabo Verde.

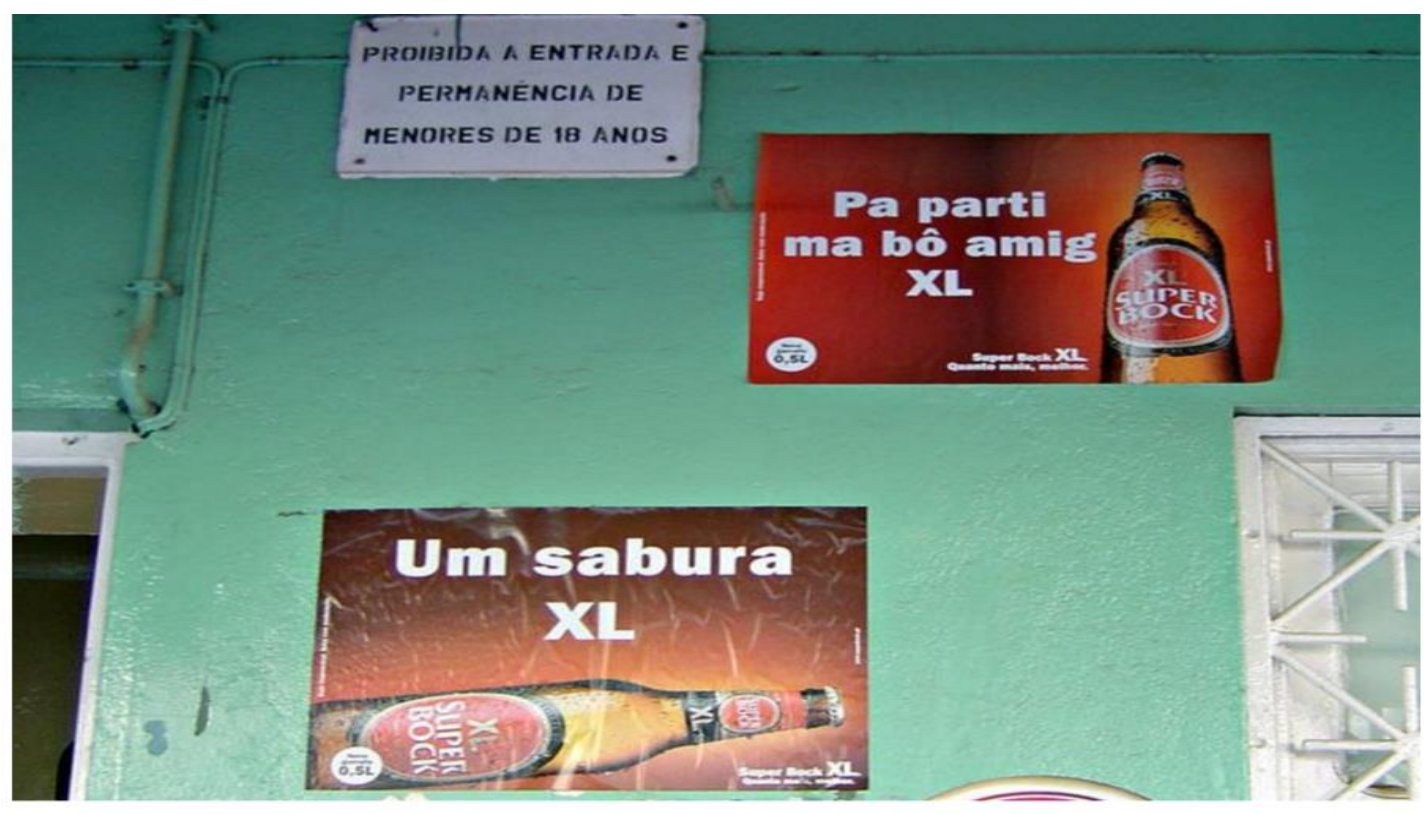

Figura 13: Situação linguística em Cabo Verde

Fonte: Alexandre, N.(2013)

\subsection{A língua cabo-verdiana com ênfase na variedade de Barlavento}

Veiga (2002: 5) aponta que, além do nascimento, nas ilhas de Cabo Verde, do homem cabo-verdiano e da cultura cabo-verdiana, nasce ainda um dos elementos mais expressivos no arquipélago: a língua cabo-verdiana (chamada de CCV, por alguns autores). Segundo alguns estudiosos, o léxico do cabo-verdiano foi formado, em sua maior parte, por palavras provenientes do português - ver Veiga (2002: 7), entre outros. 
Embora faltem estudos para comprovar empiricamente tal afirmação, esses pesquisadores aventam a hipótese de que "provavelmente, o material linguístico do CCV terá provindo, em grande parte, do português quinhentista, mas a esse material foi insuflado um espírito novo" (VEIGA, 2002: 8).

$\mathrm{Na}$ subseção (2.1.1), apresentamos as teorias de cunho substratistas na explicação da formação dos crioulos. Essas teorias passaram a ter também importância no estudo do cabo-verdiano. Delgado (2009: 98) afirma que "do código cabo-verdiano fazem parte como línguas de substrato um vasto leque de línguas africanas, como por exemplo, o Wolof, o Mandinga, Malinké, o Bambaran, entre outras". Entre essas línguas, Lopes da Silva (1984: 32) propõe que foram as línguas do grupo linguístico Mandinga que mais influenciaram na formação do cabo-verdiano. Atente o leitor para o fato de que essas línguas apontadas na citação são faladas no continente africano nos atuais países de Guiné Bissau e Senegal.

\subsubsection{Um enfoque do cabo-verdiano enquanto sistema linguístico}

$\mathrm{O}$ arquipélago de Cabo Verde é dividido em dois grupos de acordo com a direção do movimento dos ventos que cruzam o arquipélago: as ilhas do norte denominadas de Barlavento, e as ilhas do sul ou Sotavento, como já apontado no capítulo 1 , subseção (1.1).

Esses dois grupos dialetais maiores, Barlavento e Sotavento, por sua vez, subdividem-se em áreas menores, haja vista que cada ilha possui seu próprio dialeto. Entretanto, de acordo com Delgado (2009: 103), o crioulo do arquipélago cabo-verdiano é caracterizado pela existência de duas grandes variedades: uma localizada em Barlavento, com epicentro em São Vicente, e outra em Sotavento, com sede na ilha de Santiago, como podemos observar no mapa abaixo, nas figuras assinaladas em vermelho $^{30}$ :

\footnotetext{
${ }^{30}$ Mapa baseado em Delgado (2009: 75).
} 


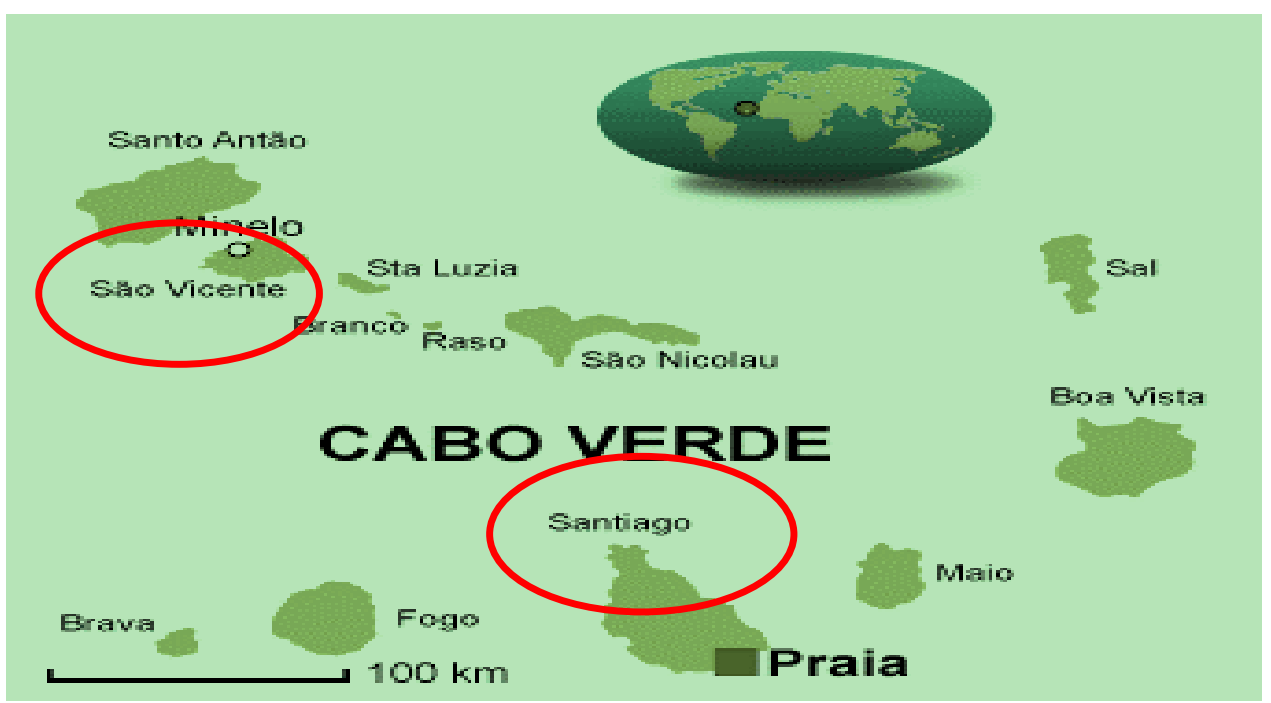

Figura 14: Epicentros das duas principais variedades do cabo-verdiano: Santiago em Sotavento, São Vicente em Barlavento.

Fonte: Gomes (2011)

A ilha de Santiago, onde se localiza a capital do país: Cidade da Praia, foi a primeira ilha a ser habitada e preserva aquele que é considerado o crioulo mais próximo do protocrioulo que deu origem ao cabo-verdiano e de outros crioulos da Alta Guiné ver Jacobs (2010: 300). A variante de Barlavento, de acordo com Delgado (2009: 103), conhecida como variante de Mindelo, formou-se a partir do século XIX, e possui forte influência do português europeu. Para Delgado (2009: 105-106), esse é um dos principais fatores para explicar as diferenças sintáticas, fonéticas e fonológicas entre Sotavento e Barlavento.

Nesse subtópico, apresentamos algumas particularidades linguísticas com o intuito de apontar diferenças entre o cabo-verdiano (tomando a variedade de Barlavento como exemplar) e a língua de superstrato: o português.

Ressaltamos que a intenção é apresentar breves considerações, objetivando apontar características diferenciais do cabo-verdiano, se comparados ao português. Desse modo, não é nossa intenção abordar, nesta subseção, uma descrição de aspectos da gramática do cabo-verdiano como um todo, pois tal descrição desse porte exigiria muito mais que um subtópico. Assim, para maiores informações a respeito da gramática do cabo-verdiano, sugerimos: Lopes da Silva (1984) e Veiga (2002) - para as variedades de Sotavento e Barlavento; Cardoso (1989) - para a variedade de Barlavento (especificamente São Nicolau); Baptista (2002) e Quint (2008) para a variedade de Sotavento. 
Logo, apresentamos, por meio da morfossintaxe nominal e verbal, dois aspectos do cabo-verdiano a fim de cotejá-lo com o português. Na morfossintaxe nominal: o gênero e o número; na morfossintaxe verbal: a marcação de tempo, aspecto e modo.

\subsubsection{Aspectos da morfossintaxe nominal: o 'gênero ${ }^{, 31}$}

Nesta subseção destacamos a categoria de 'gênero' em cabo-verdiano. Sobre a categoria linguística 'gênero', Câmara Jr. (1972: 78) aponta que trata-se de:

[...] uma distribuição em classes mórficas para os nomes, da mesma sorte que o são as conjugações para os verbos. A única diferença é que a oposição masculino - feminino serve frequentemente para em oposição entre si distinguir os seres por certas qualidades semânticas [...]

Segundo Câmara Jr (1996), em português, as desinências de gênero são [ø] para "masculino" e [a] para "feminino":

Nessas condições, o que convém à descrição gramatical é se concentrar no mecanismo de flexão que cria nos substantivos portugueses uma oposição de gênero.

Ela consiste, essencialmente, na utilização da vogal /a/, no seu alofone de posição átona [a], como índice de feminino em oposição a uma forma, masculina, em que falta esse /a/.

Câmara Jr (1996: 150)

Como se vê no excerto, para Câmara Jr. (op cit.), a desinência [o] não é marca de gênero masculino, mas sim uma "ausência". A estrutura nominal em português, segundo Câmara Jr. (1996: 156), organiza-se em torno de um tema - raiz mais vogal/consoante temática (além do morfema de flexão (ou derivação)). As vogais temáticas nominais são [o], [e] e ainda os temas consonantais [s], [r], [1].

A seguir, exemplificamos o gênero em português, de acordo com Câmara Jr. (1996: 150, 156) em:
(1) (o) doutor [ø]
(a) doutor [-a]
(2) (a) máquin [-a]
*(o) máquin [-o]
(3) (o) menin-o [ø]
(a) menin [-a]
(4) (o) pot-e
*(a) pot-e
(5) (o) lápi-s
*(a) lápi-s
(6) (o) computado-r
* (a) computado-r
(7) (o) répti-1
*(a) réptil ${ }^{32}$

\footnotetext{
${ }^{31}$ Nesta dissertação os dados do cabo-verdiano não referendados são pertencentes ao corpus de nossa pesquisa.

${ }^{32} \mathrm{O}$ que se tem é: réptil macho e réptil fêmea.
} 
De acordo com Câmara Jr (1996), estruturalmente, uma subcategoria de gênero se opõe a outra. Logo, uma palavra só apresenta a marca de gênero por "oposição". Assim, em (1), o morfema [ø], em doutor, se opõe ao morfema [a] doutor-a. No entanto, em (2), não se vê "oposição" alguma ao morfema [a] de máquina. Seguindo Câmara Jr. (1996: 150), não se tem, em português, por exemplo, uma palavra como *máquino. Logo, a desinência [o] não é considerada morfema de "gênero masculino" (por oposição a [a]) - ver exemplo (3) em que o morfema [o], em menin-o, não marca "gênero masculino", mas sim vogal temática na língua portuguesa. Observa-se, ainda, nos exemplos (4)-(7) dados com a vogal temática [e] e as consoantes temáticas [s], [r] e [1], respectivamente. Nestes exemplos, não se verifica a flexão de gênero. Esta é atestada, no entanto, na flexão do determinante, marcando o gênero default "masculino".

Logo, no tocante aos dados acima e, particularmente ao conjunto (4)-(7), é ainda importante enfatizar o que Câmara Jr. (1996: 152) chama de "princípio fundamental da morfologia do gênero em português": a flexão do artigo determinante.

Importante ainda dizer que, a categoria 'gênero', segundo Câmara Jr (1996), e outros autores, tem sido considerada, no português, como parte da morfologia flexional, embora não seja consensual. Alguns autores argumentam que o morfema [a], marcador do gênero feminino deva ser analisado como sufixo derivacional. Entre os autores que defendem a ideia encontra-se Bechara $(2006)^{33}$.

Chamamos ainda a atenção do leitor para o que Câmara Jr. (1996: 149) chama de "[...] diferenciações lexicais determinadas pela distinção do sexo como princípio semântico". Segundo o autor (op cit.), tais diferenciações têm importância na descrição linguística, mas não para o estudo do gênero como flexão gramatical. Câmara Jr. referese, entre outros, a processos lexicais como heteronímias das raízes (ex.: homem mulher), a derivação lexical (ex.: ator - atriz, lebrão - lebre), ou ainda substantivos designativos de espécies animais (ex.: a cobra macho - a cobra fêmea).

Em cabo-verdiano, também se atesta o gênero como flexão gramatical. Ressaltamos que, por nosso trabalho enfatizar a variante de Barlavento, apresentamos exemplos da variedade de São Vicente, e de São Nicolau ${ }^{34}$ :

\footnotetext{
33 Exemplificando com palavras como: barco/barca, lobo/loba, jarro/jarra, Bechara (2006: 132) argumenta em favor do processo de derivação na marcação do gênero em português porque as formas do masculino e do feminino expressam significações inerentemente distintas umas das outras.

${ }^{34}$ Para exemplos de Sotavento, consultar as obras sugeridas na subseção (2.2.1).
} 
Variedade de São Vicente ${ }^{35}$ :

(8) amige/amiga (amigo/amiga)

(9) profesor/profesora (professor/professora)

(10) falador/faladera (falador/faladeira)

Observe que, os exemplos de São Vicente corroboram a flexão de gênero no caboverdiano por meio da "oposição" das desinências [ø] e [a]. Seguindo Câmara Jr. (1996: 150), o que temos acima seria a desinência [ø] para o masculino e [a] para o "feminino", que pode ser atestada nas palavras amig-e- $\varnothing /$ amig-a (8); profeso-r-ø/ profesor-a (9); falado-r-ø/falader-a (10). Logo, em amig-e (8); profeso-r (9); falado-r (10) atestamse desinências de vogal e consoantes temáticas.

Embora os exemplos de São Vicente apresentem a flexão de gênero, não se pode, contudo, atestar, no cabo-verdiano o que Câmara Jr. (1996: 152) chama de "princípio fundamental da morfologia do gênero em português": a flexão do artigo determinante. Análises atuais sobre o cabo-verdiano, ligadas ao sintagma nominal (SN), apontam que os nomes nessa língua não são acompanhados, em geral, de determinante e podem ser interpretados tanto como definidos quanto indefinidos - ver Miranda, Oliveira \& Gomes (2010). Em cabo-verdiano, atesta-se a presença dos morfemas un/uns; kel/kes; segundo Miranda, Oliveira \& Gomes (2010: resumo):

[...] A utilização de un / uns está, em geral, associada a introdução de novos referentes, seu uso, contudo, não é frequente. Existe, ainda, a partícula kel/kes que parece veicular, entre outras coisas, definitude. Tal emprego, todavia, tampouco se dá frequentemente. O estatuto de kel, em caboverdiano, causa algumas divergências entre os pesquisadores da língua. [...]

Alexandre \& Soares (2004), Baptista (2007) e Quint (2000) advogam que kel, por vezes desempenhe o papel de artigo definido na língua. Contudo, como apontado no excerto acima, esta análise não é consensual. Para detalhes sobre a análise do SN em caboverdiano, ver Miranda (2013).

No cabo-verdiano se atesta, tal qual em português, o que Câmara Jr. (1996: 149) referese como "[...] diferenciações lexicais determinadas pela distinção do sexo [...]". Atentese para os exemplos abaixo:

Variedade de São Nicolau ${ }^{36}$ :

\footnotetext{
${ }^{35}$ Dados de Veiga (2002: 57); a numeração é nossa.
} 

(11) om/mjer
(homem/mulher)
(12) bod/kabra
(bode/cabra)
(13) rapazin/mnininha (rapaz/menina)
(14) kabrit mótx (cabrito macho) kabrit femja (cabrito fêmea)
(15) fidji mótx (filho macho) fidji femja (filho fêmea)

\subsubsection{Aspectos da morfossintaxe nominal: o 'número'}

No português, segundo Câmara Jr. (1972: 82 - 86), o 'número' é parte da flexão nominal: (i) há, em oposição a um zero (ø) singular, o arquifonema /S/ das quatro fricativas não bilabiais em posição posvocálica final - alormofia dita fonológica ${ }^{37}$; (ii) há um mecanismo puramente morfológico: (a) alomorfe zero (ø) - ex. flores; (b) mudanças morfofonológicas - ex. nomes terminados por consoantes no singular: animal/animais, anzol/anzóis ${ }^{38}$.

Desse modo, nota-se que o português é dotado de um complexo sistema de marcação de 'número' por meio da flexão.

No cabo-verdiano, entretanto, o processo acima, que foi apontado para o português, parece não ocorrer. Vejamos os exemplos abaixo:

Variedade de São Vicente ${ }^{39}$ :

(17) txeu kabra (lit.: muitas cabra)

(18) dôs amige (lit.: dois amigo)

(19) nhas fidje (lit.: meus filho)

Variedade de São Nicolau ${ }^{40}$ :

(20) a. (singular) kel mnina (aquela menina)

b. (plural) kes mnina (lit.: aquelas menina)

(21) a. (singular) un mnina (uma menina)

b. (plural) uns mnina (lit.: umas menina)

\footnotetext{
${ }^{36}$ Dados de Cardoso (1989: 22); a numeração é nossa.

${ }^{37}$ Como apontado por Câmara Jr. (1972: 84), exemplifica-se com uam possibilidade de fonema /z/, quando se dá o fenômeno da 'ligação' diante de vogal inicial, com mudança do corte silábico (rosas abertas /rò-za-za-bèr-tas $\%$

${ }^{38}$ Para outros processos ver Camara Jr. (1972).

${ }^{39}$ Dados de Veiga (2002: 9). A numeração é nossa.

${ }^{40}$ Dados de Cardoso (1989: 21). A numeração e tradução literal são nossas.
} 
(22) a. (singular) un rapaz bnit (um rapaz bonito)

b. (plural) uns rapaz bnit (lit.: uns rapaz bonito)

Em (17)-(18) - dados de São Vicente - e (20)-(22) - dados de São Nicolau - nota-se que o 'número' é marcado pelo quantificador e pelo determinante na língua, haja vista que os nomes que os sucedem não atestam a marcação de 'número'.

Entretanto, chamamos a atenção para a seguinte exceção: ${ }^{41}$

Variedade de São Vicente ${ }^{42}$

(23) amedjeres (mulheres)

No exemplo (23), a desinência [-es] parece apontar para um caso de morfema de 'flexão de número' nos nomes em cabo-verdiano. A flexão de número no sistema nominal, por meio da desinência [s] tem sido atestada, também, no crioulo de Guiné Bissau - ver Kihm (1994: 131).

\subsubsection{A Marcação do Tempo, Aspecto e Modo em cabo-verdiano (TAM)}

De acordo com Bakker, Post \& Voort (1994: 247), as categorias de tempo, aspecto e modo - daqui em diante, TAM - são fenômenos universais nas línguas, entretanto, elas podem ser marcadas de maneiras variadas.

Segundo Camara Jr. (1972: (94 - 95), a flexão verbal em português se distingue por desinências cumulativas modo-temporais (DMT) e número-pessoais (DNP).

O autor (op cit.) propõe uma regra de análise estrutural para o vocábulo verbal em português que consisite em:

- Raiz + Vogal Temática (VT) + Desinência Modo-Temporal (DMT) +

Desinência Número-Pessoal (DNP) ${ }^{43}$

Em (24), exemplifica-se a análise estrutural mattosiana:

(24) fal-a-va-s

\begin{tabular}{|l|l|l|l|}
\hline Raiz & Vogal Temática & DMT & DNP \\
\hline fal & $-\mathrm{a}$ & -va & - s \\
\hline
\end{tabular}

\footnotetext{
${ }^{41}$ Ao nos referirmos a um único exemplo, não queremos, contudo, dizer que esse possa ser o único caso da língua. É, porém, o único que atestamos.

${ }^{42}$ Dados de Veiga (2002: 9). A numeração é nossa.

${ }^{43}$ Adaptado de Câmara Jr. (1972: 94).
} 
A análise que vem sendo feita para as línguas crioulas, de modo geral, diferentemente à análise apresentada em (24) para o português, é a de que essas línguas atestam TMA não por meio de morfemas de flexão, mas por um sistema de partículas alocadas antes do verbo - ver Bakker, Post \& Voort (1994: 248).

Na língua cabo-verdiana, as partículas TMA, segundo a literatura atual, são: ta, sta, e dja. Atente para os seguintes exemplos:

Variedade de São Nicolau:

(25) Un musinh k'panhó-b bo bol sei ta korê

Um musinh k' panhó- $b$ bo bol sei ta korê

DET menino $\mathrm{PRO}_{\text {rel }}$ roubar $2 \mathrm{SG}$.OBJ OBJ bolo sair TMA correr

O menino que te roubou o bolo saiu correndo.

\section{(26) É ôm k'ta papia d'más}

$\begin{array}{llllll}\mathbf{E} & \hat{\text { Ôm }} & \mathbf{k}^{\prime} & \text { Ta } & \text { papia } & \text { d'más } \\ \text { COP } & \text { homem } & \text { COMP } & \text { TMA } & \text { falar } & \text { Demais }\end{array}$

É homem que fala demais

Em (25) e (26), atesta-se a presença das partículas TMA ta. Nos dois casos, essa partícula é mais aspectual do que temporal. Observe que, em (25), sua presença marca um fato ocorrido no pretérito (com função aspectual); em (26), a marcação é evidentemente "habitual".

De acordo com Baptista (2002: 78-86), a partícula sta pode marcar aspecto progressivo e tempo futuro; a partícula dja, o aspecto perfectivo - para maiores exemplos e detalhamentos ver: Baptista (2002: 78-86); Quint (1998: 225).

Poderíamos, portanto, encerrar esta seção sobre a morfologia verbal, afirmando que o cabo-verdiano não atesta flexão na categoria verbo. "Poderíamos", se não fosse o caso do morfema -ba, muito discutido na literatura acerca dessa língua nos últimos anos $^{44}$. Para tal, enfatizamos o trabalho de Holm (2013), que considera a partícula -ba um remanescente de saba, encontrado em textos arcaicos, significando era, portanto uma marca de flexão verbal.

Importante ressaltar que, até onde sabemos, a presença do morfema -ba tem sido atestada no cabo-verdiano, como morfema de flexão verbal. Outro fato importante é que

\footnotetext{
${ }^{44}$ Baptista (2002: 201) analisa o morfema -ba como flexão, no entanto, associa a entrada desse morfema na língua recentemente. Logo, para Baptista (o cit.), -ba é fenômeno de descrioulização. Jacobs (2012: 212), explica a presença de -ba na língua por duas maneiras: (i) o morfema tem relação com o -va do português; (ii) o morfema liga-se a questões de substrato - trata-se de uma forma pós-verbal (ka)ba. (Essa expicação de Jacobs (2012) associa-se à explicação de Kihm (1994: 103) dada para o -ba no crioulo de Guiné Bissau.)
} 
a literatura tem atestado, dados ligados, em Cabo Verde, somente à variedade de Sotavento - ver Jacobs (2012: 212) ${ }^{45}$. No entanto, apresentamos dados com exemplos de Barlavento.

Observe o dado:

Variedade de São Nicolau ${ }^{46}$

(27) $\mathbf{N}$ odjaba Ped d' Kakai gaturdia

\begin{tabular}{|l|l|l|l|l|l|l|}
\hline N & Odja & ba & Ped & d' & Kakai & gaturdia \\
\hline 1SG.Nom. & Ver & Perfect & Pedro & de & Kakai & anteontem \\
\hline
\end{tabular}

Lit.: "Eu tinha visto Pedro de Kakai anteontem" (Eu vi o Pedro da Kakai antes de ontem)

Atente ainda para mais esta observação e dado:

Variedade de São Nicolau ${ }^{47}$

(28) Smana pasôd, N sabe-ba ma bebe d'Lurdes dja nasê

\begin{tabular}{|l|l|l|l|l|l|l|l|l|l|l|}
\hline Smana & pasôd & N & sabe & ba & ma & bebe & d' & Lurdes & Dja & Nasê \\
\hline $\begin{array}{l}\text { Seman } \\
\text { a }\end{array}$ & passada & 1SG.Nom & saber & Imperf. & Comp & bebê & de & Lurdes & TMA & nascer \\
\hline
\end{tabular}

"Lit.: Semana passada eu sabia que o bebê de Lurdes havia nascido"

Segundo Francisco Lopes ${ }^{48}$ (comunicação pessoal), o contexto para a sentença em (28) é: "quando a sentença foi pronunciada, o 'eu' da enunciação refere-se a uma 'semana passada' em que naquele momento da enunciação, ele, o 'eu da enunciação', sabia que o bebê da Lurdes havia nascido; mas agora (no momento da enunciação) "não é mais o caso')." No entanto, a sentença (28), pode ainda ser pronunciada sem a desinência ba $^{49}$.

\footnotetext{
${ }^{45}$ Referimos-nos a -ba no cabo-verdiano, já que este morfema também é atestado no crioulo de Guiné Bissau - ver Kim (1994: 99).

${ }^{46}$ Dado fornecido por Francisco João Lopes.

47 Dado fornecido por Francisco João Lopes, nativo da ilha de São Nicolau, Cabo Verde, mestre pela Universidade de São Paulo. Atualmente é doutorando pela mesma instituição.

${ }^{48}$ Ver nota 42.

49 Atente o leitor que estamos considerando -ba, não como 'partícula', mas como desinência de flexão verbal na língua cabo-verdiana. Logo, ratificamos análises como as de Holm (2013) e de Francisco Lopes (em comunicação pessoal).
} 
Variedade de São Nicolau ${ }^{50}$

(29) Smana pasôd, N sub ma bebe d'Lurdes dja nasê

\begin{tabular}{|l|l|l|l|l|l|l|l|l|l|}
\hline Smana & pasôd & N & sub & ma & bebe & d' & Lurdes & dja & Nasê \\
\hline $\begin{array}{l}\text { Seman } \\
\text { a }\end{array}$ & passada & 1SG.Nom & soube & Comp & bebê & de & Lurdes & TMA & Nascer \\
\hline
\end{tabular}

"Lit.: Semana passada eu soube que o bebê de Lurdes nasceu"

Observe, que, em (29), sem a desinência -ba, a forma verbal é sub, um morfema que lembra "soube" do português. Segundo Francisco Lopes (comunicação pessoal), qualquer falante de São Nicolau pronunciaria a estrutura em (29): um idoso ou uma criança. Para Francisco Lopes, portanto, "não se trata de influência do português atual ou descrioulização".

Portanto, ao término desta seção, diríamos que, até mesmo na morfologia verbal, em que se pode perceber uma diferenciação maior entre a gramática cabo-verdiana e a do português, atesta-se caso de flexão verbal, como a apontada por meio do morfema ba, exemplificado em (27)-(29). Assumimos análises como a de Holm (2013) em que o morfema -ba seja desinência de flexão verbal e que tenha entrado na estrutura da língua não por efeito de descrioulização.

\subsection{Síntese do capítulo}

Nesse capítulo, abordamos, de modo geral, sobre algumas hipóteses a respeito da gêneses das línguas crioulas, chamando a atenção do leitor para o fato de que se tomarmos a gêneses do cabo-verdiano, como enfoque de análise, a única abordagem que não caberia seria a 'gradualista'. Em seguida, tratamos de uma descrição mais recente acerca dos conceitos de pidgin e crioulo, abordando, inclusive, o conceito de pidgincrioulo.

Traçamos um panorama sociolinguístico de Cabo Verde, enfatizando a situação bilíngue/diglóssica do arquipélago que convive com a língua materna - o cabo-verdiano e a língua oficial - o português.

$\mathrm{Na}$ seção subsequente, abordamos aspectos da morfossintaxe nominal da variedade em destaque da língua, ressaltando as categorias de 'gênero' e de 'número', e ainda a marcação do tempo, aspecto e modo através das partículas TMA. Nesse tópico,

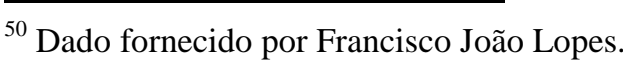


enfatizamos o trabalho de Holm (2013), que considera a partícula -ba como um remanescente de saba, encontrado em textos arcaicos, significando era. Portanto, para Holm (op cit.), -ba não é um caso de descrioulização na língua, mas sim uma clara marca de flexão verbal. 


\section{CAPÍTULO 3 \\ REFERENCIAL TEÓRICO-METODOLÓGICO}

\subsection{Introdução}

Neste capítulo, apresentamos o referencial teórico-metodológico utilizado nesta dissertação.

No que diz respeito à teoria, abordamos a categoria sintático/discursiva foco, o processo sintático "clivagem" bem como os pressupostos teóricos da teoria Fonologia Entoacional Métrica Autossegmental (doravante, Fonologia Entoacional). No tocante à metodologia, apresentamos todos os passos que nos levaram à organização do corpus para esta pesquisa.

A investigação preliminar do foco da categoria 'sujeito' em cabo-verdiano, proposta nesta dissertação, insere-se no conjunto de pesquisas que vêm analisando este constituinte e a categoria foco nas variedades brasileira e europeia do português. Na investigação sobre o 'foco informacional' nessas duas línguas, por exemplo, nítidas diferenças têm sido atestadas, como apontado por diversos pesquisadores - cf. Âmbar (1992, 1997, 1999), Costa (1996,1998, 2004), Kato \& Raposo (1996), Kato (1999, 2000), Modesto (2001), Tavares Silva (2004) e Fernandes (2007).

No tocante ao processo sintático "clivagem", nesta dissertação, corroboramos análises que se observa em Modesto (2001), ratificada em Mioto \& Negrão (2007). Para Mioto \& Negrão (op. cit.), nem toda construção em que um dado elemento ocorre 'ensanduichado' entre a cópula e a palavra 'que' contém uma relativa, diferentemente do que afirmam Braga, Kato \& Mioto (2009: 283).

Para análises fonológicas, utilizaremos o arcabouço teórico Fonologia Entoacional com base em Pierrehumbert (1980); Pierrehumbert e Beckman (1988); Ladd (1980, 1983, 1990, 1996) entre outros. Considerações sobre os pressupostos dessa teoria serão tecidas ao decorrer deste capítulo.

Chamamos a atenção para o fato de que não é parte do escopo deste trabalho uma comparação do foco da categoria 'sujeito' no cabo-verdiano com as variedades brasileira e europeia do português (doravante PB e PE). No entanto, de certa maneira, alguns traços, acerca de semelhanças e/ou diferenças entre o PB e o PE e o caboverdiano, no tocante à marcação do foco serão abordados. Outro ponto que 
apresentamos é relacionado à tipologia do foco, tanto em línguas do superstrato quanto em línguas do substrato. Verificamos a tipologia do foco no cabo-verdiano, variedade de São Nicolau, e a cotejamos com as tipologias do superstrato e substrato.

\subsection{A Categoria Foco}

No tocante aos estudos sobre foco, assumimos, nesta pesquisa, a abordagem de foco de Zubizarreta $(1998,7)$ em que "[...] foco é definido em termos da noção discursiva de pressuposição: o foco é a parte não pressuposta da sentença". Logo, no que se refere a esta categoria sintática discursiva, não estamos centrados em torno da dicotomia informação 'nova' vs. informação 'velha', como se observam em abordagens funcionalistas.

Zubizarreta (1998: 7) propõe que a interpretação de um constituinte focalizado deva ser representada por meio de duas asserções (A) no nível da Forma Lógica (LF): A1, A2, chamadas de estrutura de asserção pela autora. Oliveira \& Jorge $(2009: 77)^{51}$ apresentam a exemplificação da estrutura de asserção(AS) dada por Zubizarreta, envolvendo a noção de foco contrastivo:

(1) João está vestindo uma camisa VERMELHA hoje (não uma camisa azul)

[João está vestindo uma camisa azul hoje]

(2) $A_{1}$ : 'Existe um $x$ tal que João está vestindo $x$

$\mathrm{A}_{2}$ : 'Não é o caso que o $\mathrm{x}$ (tal que João está vestindo $\left.\mathrm{x}\right)=$ uma camisa azul $\&$

$\mathrm{O} \times($ tal que tal que João está vestindo $\mathrm{x})=$ uma camisa vermelha

[...] No caso de foco contrastivo, como se vê em (1), a asserção $A_{1}$, em (2), é constituída pela pressuposição existencial "João está vestindo uma camisa azul hoje".

A asserção $\mathrm{A}_{2}$ é composta de duas partes:

- A primeira verifica a negação do valor de verdade atribuído, previamente, à variável x (uma camisa azul);

- A segunda atribui um novo valor de verdade para essa variável: "uma camisa vermelha".

A categoria foco está ligada a uma tipologia bem demarcada na literatura - Kuno (1972) e Chafe (1976) propuseram uma diversidade funcional no sistema de foco. Kuno (1972) aponta que distinções como "tema", "contraste", "listagem exaustiva" e

\footnotetext{
${ }^{51}$ Os dados foram renumerados.
} 
"descrição neutra" têm papel decisivo na sintaxe do japonês (tendo seus equivalentes também na sintaxe do inglês).

Chafe (1976), por sua vez, amplia a tipologia de Kuno (1972): é de Chafe a terminologia "foco contrastivo". Watters (1979) enriqueceu a tipologia de foco proposta por Kuno e Chafe, argumentando, a partir de seus estudos sobre aghem, em favor da existência de foco polar e foco polar contra-assertivo.

Entretanto, foram Zubizarreta (1998) e Kiss (1998) que delimitaram a principal tipologia de foco atestada na literatura no tocante a línguas indoeuropeias:

(i) foco de informação (foco assertivo);

(ii) foco contrastivo;

(iii) foco de listagem exaustiva.

Polli $(2008,27)$ apresenta algumas definições a respeito desses tipos de foco. Segundo o autor, foco assertivo ou de informação se refere à informação que o falante supõe que seu interlocutor não possui. Observe o exemplo abaixo ${ }^{52}$.

(3) Você quer saber o que a Joana comprou de presente para o pai? Bem, eu acho que ela comprou [Foc uma camisa]

Já o sintagma com interpretação de foco contrastivo é o fornecido pelo enunciado prévio (que preenche a variável x) e que o falante-ouvinte substitui por outro.

Observe as sentenças abaixo ${ }^{53}$ :

(4) a. O João beijou a Maria

b. Não! O João beijou [ Foc a Marta]

ou

c. Foi [Foc a Marta] que o João beijou

O terceiro tipo apontado, o foco de listagem exaustiva, pode ser considerado como sendo a informação na qual o falante declara que o restante da sentença é verdadeiro somente em relação a ela. Ou seja, a propriedade da exaustividade se realiza através da exclusão (x e somente $\mathrm{x}$ ). Vejamos os exemplos abaixo ${ }^{54}$ :

(5)a. Todos os nossos vizinhos são chatos, né?

b. Não. Chato é [Foc o da frente]

ou

\footnotetext{
${ }^{52}$ Dados (1.07) de Polli (2008: 27)

${ }^{53}$ Dados (1.08) de Polli (2008: 27)

${ }^{54}$ Dados (1.09) de Polli (2008: 28)
} 
Mioto (2003: 5), baseando-se na tipologia de foco apontada por Zubizarreta (1997), e na proposta de traços de [contrastividade] e [exaustividade] de Kiss (1998), apresenta o seguinte quadro tipológico:

a) $[$ - contrastivo, - exaustivo $]=$ foco de informação / não-contrastivo

b) $[-$ contrastivo, + exaustivo $]=$ foco de identificação / de listagem exaustiva

c) $[+$ contrastivo, - exaustivo $]=$ "inexistente"

d) $[+$ contrastivo, + exaustivo $]=$ foco contrastivo

De acordo com Mioto (2003: 5), um foco com os traços de (c) [+contrastivo, exaustivo] não é possível em línguas naturais.

A literatura africanista aponta para uma tipologia de foco mais ampla que a citada na literatura sobre foco em línguas indoeuropeias. Oliveira (2005: 130) chama a atenção para o trabalho de Watters (1979) sobre foco em aghem, uma língua africana falada em Camarões, oeste da África:

As observações de Watters (op. cit.) sobre as propriedades de escopo de foco em aghem o levaram a reconhecer outros dois tipos de foco que não haviam sido propostos antes na literatura. Logo, o esquema proposto por Watters vai além dos outros esquemas de tipos de foco propostos previamente por Kuno (1972) e Chafe (1976). Watters acrescenta à tipologia de foco de Kuno e Chafe os seguintes tipos: foco polar e foco polar contra-assertivo.

Mesmo se tratando de uma informação de foco sobre uma língua particular do oeste da África, é importante, para o escopo desta dissertação, que se aponte a descrição de foco de Watter (1979), pois, trata-se de descrição de foco de "línguas de substrato" no contexto desta dissertação ${ }^{55}$.

Para entendermos um pouco melhor as definições de foco polar e polar contraassertivo, observe as sentenças abaixo ${ }^{56}$ :

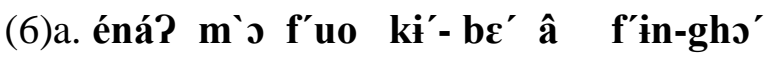 \\ Inah $\mathrm{P}_{2}$ dar fufu para amigos \\ Inah deu fufu para (seus) amigos}

\footnotetext{
${ }^{55}$ Embora os estudos em línguas crioulas do oeste da África não sejam, classicamente, inseridos no conjunto dos estudos das línguas africanas, pesquisas e pesquisadores insistem no fato de que essas línguas não se diferem em nada das línguas africanas - e de outras línguas naturais - ver capítulo 2, subseção (2.1.1.), "hipóteses universalistas". Logo, o cabo-verdiano, é uma língua Africana. À parte este fato, o cabo-verdiano, estudado nesta dissertação, tem como substrato, línguas africanas da família NígerCongo. Nesse sentido, é importante apontar, ainda que sucintamente, o "foco na África".

${ }^{56}$ Watters (1979), apud Oliveira (2005: 134; dados $106 \mathrm{a}-\mathrm{b}$, renumerados).
} 


\section{b. éná? má'á fúo be'-ko' â f'in-gho'}

Inah $\mathrm{P}_{2} / \mathrm{FOC}$ dar fufu para amigos

De acordo com Watters (1979), há diferenças formais entre as duas sentenças acima. Em (6b), o autor aponta para um marcador de foco completivo ' $m a$ ' 'a', indicado na glosa por $\mathrm{P}_{2} / \mathrm{FOC}$, e uma forma diferente para o objeto ' $f u f u$ ' - $\mathrm{b} \varepsilon^{\prime}-\mathrm{ko}$ '. Desse modo, segundo Watters (1979), a sentença (6b) tem um foco marcado no valor de verdade. Esse tipo de foco, o autor chama de foco polar:

Foco Polar: o valor de verdade "verdadeiro" ou "falso" que o falante afirma com relação a uma sentença.

Watter (1979) apud Oliveira (2005: 131)

A partir da análise do foco polar realizada por Watters (op cit.), o autor propôs ainda "foco polar contra-assertivo" em aghem. Observe a sentença (7) abaixo ${ }^{57}$ :

(7) f'ì á má'á be'-ko' \{ án 'sóm \} zi

Amigos SM $\mathrm{P}_{1} / \mathrm{FOC}$ fufu fazenda comer

Os amigos também comeram fufu na fazenda

De acordo com Oliveira (2005: 132), que segue a interpretação de Watters (op cit.) - os constituintes entre colchetes foram posicionados imediatamente antes do verbo, que ocupa a posição final da sentença. Tal mudança de ordem de constituintes ocasiona uma leitura contrastiva em aghem. Entretanto, no caso de estruturas como (7) acima, em aghem, o foco contra-assertivo não está em um determinado elemento da sentença, e sim no valor de verdade da sentença. Este tipo de foco, assim como o foco polar, é indicado por $m a ́$ 'á $-\mathrm{P}_{1} / \mathrm{FOC}$. Desse modo, de acordo com o autor:

Foco polar contra-assertivo: é o valor de verdade "verdadeiro" ou "falso" que o falante afirma, contradizendo uma asserção prévia do ouvinte com relação ao valor de verdade da sentença.

Watter (1979) apud Oliveira (2005: 133)

Além do foco ser marcado tipologicamente, como apontado nos parágrafos acima, a literatura refere-se a componentes da língua que se envolvem na marcação do foco, especificamente mecanismos morfossintáticos e fonológicos.

No tocante à morfossintaxe, o foco pode ser marcado pela construção conhecida como "clivagem", única estrutura aceita para marcação do foco no constituinte sujeito

57 Watters (1979) apud Oliveira (2005: 132; dado 104, renumerado). 
em cabo-verdiano, como veremos adiante, ainda neste capítulo e também no capítulo 4.

Com relação à fonologia, o foco, em línguas como o português, por exemplo ${ }^{58}$, é marcado por meio de realce prosódico. Esse tópico será alvo de nossa análise, também no capítulo (4).

\subsection{Referencial teórico do 'foco'}

Nesta dissertação, como já dito, abrimos duas seções: uma de caráter teórico (fonológico), no qual abordamos as teorias a serem utilizadas na construção da dissertação; outra de caráter metodológico, concernente à caracterização dos informantes, transcrição e organização do corpus.

Antes de abordarmos os aspectos teóricos fonológicos, apresentamos, brevemente, considerações sobre o processo de checagem do 'foco' em PB e em PE e ainda em São Nicolau.

\subsubsection{Considerações sobre a checagem do 'foco' em $P B$ e PE}

Ao se falar sobre a marcação do 'foco' da posição 'sujeito' em PB e em PE, é importante destacar a questão do que se conhece como "ordem neutra" e "ordem marcada" nessas línguas.

Âmbar (1992: 45) verifica que, em PE, há seis ordens possíveis que resultam de diferentes combinações dos termos sujeito $(\mathrm{S})$, verbo $(\mathrm{V})$ e objeto $(\mathrm{O})$ : SVO, SOV, VSO, OSV, OVS e VOS. Observe os exemplos abaixo ${ }^{59}$ :

\begin{tabular}{|c|l|}
\hline (8) a. A Joana comeu a sopa (SVO) & d. A sopa, a JOANA comeu (OSV) \\
\hline b. A Joana, a sopa, comeu (SOV) & e. A sopa, comeu a Joana (OVS) \\
\hline c. Ontem comeu a Joana a sopa (VSO) & f. Comeu a sopa, a JOANA (VOS) \\
\hline
\end{tabular}

Quadro 9: Ordens sentenciais em PE

Fonte: Âmbar (1992: 45)

Nos exemplos acima, conforme Âmbar (op cit.), com exceção da sentença em (8a), todas as outras exigem a verificação de certas condições. A sentença em (8a) é a única que não requer pausa ou acento contrastivo em um dos constituintes.

\footnotetext{
${ }^{58}$ A língua de superstrato do cabo-verdiano.

${ }^{59}$ Âmbar (1992); dados (53 a-f), renumerados.
} 
Âmbar (1992: 45) aponta ainda para o fato de que as vírgulas representam pausas prosódicas, e os constituintes, em letras maiúsculas, as palavras nas quais recai o acento contrastivo.

Na sentença (8c), embora não se observe a presença de vírgulas, o aparecimento do constituinte 'ontem' (não presente nas demais construções), de acordo com a autora (op cit.), desempenha a mesma função que os elementos pausa e acento contrastivo nas outras sentenças.

Âmbar (op.cit) faz a distinção entre ordem básica, ou menos marcada, e a forma marcada na língua. De acordo com a autora, por 'ordem marcada' entende-se que essa ordem está associada a uma condição específica, seja de ordem sintática, semântica, prosódica ou pragmática. Desse modo, para Âmbar (1992: 45), a ordem SVO da sentença (8a), que não exige acento contrastivo, pausa, advérbio em posição inicial, QU-interrogativo ou qualquer outro elemento, é a ordem neutra (ou a básica) em PE. Entretanto, esta ordem, apesar de ser a ordem neutra no PE, em alguns casos, não é aceita, como ocorre, por exemplo, nas sentenças interrogativas-QU.

Em sentenças com verbos inergativos em PE, segundo Âmbar (1992: 46), a ordem neutra é SV, como exemplificado abaixo em (9a):

(9)a. O João correu.

b. \# Correu o João ${ }^{60}$.

Portanto, a ordem VS em (9b), por se tratar de uma sentença com verbo inergativo, é pragmaticamente anômala em contexto neutro. Em PE, o contexto de focalização do sujeito em sentenças simples, como verbos monoargumentais como em (22), se dá por meio da ordem VS - cf. Âmbar (1992), (1997) e (1999); Costa (1996), (1998) e (2004).

No que se refere ao PB, conforme Silva (2001), Tavares Silva (2004) e Fernandes (2007) - entre outros - a ordem neutra assumida para esta variedade de português é, como o PE, também SVO. Observe os exemplos abaixo ${ }^{61}$ :

\begin{tabular}{|c|c|}
\hline (10)a. A Joana comeu a sopa (SVO) & d. A sopa, a JOANA comeu (OSV) \\
\hline b. *A Joana, a sopa, comeu (SOV) & e. *A sopa, comeu a Joana (OVS) \\
\hline
\end{tabular}

\footnotetext{
${ }^{60} \mathrm{O}$ símbolo (\#) marca uma sentença anômala pragmaticamente. A sentença (22b) seria pragmaticamente "boa" em PE em resposta a uma sentença-contexto como: (i) Quem correu? R.: (22b) Correu o João, em contexto de foco informacional, haja vista que, em PE, a ordem $\mathrm{V}(\mathrm{O}) \mathrm{S}$ só é aceita para este tipo de foco, mas não para foco contrastivo - ver Fernandes (2007).

${ }^{61}$ Os exemplos, colocados no quadro, são baseados nos dados de Âmbar (1992: 45), tomados para o PB por Fernandes (2007: 71).
} 
c. * Ontem comeu a Joana a sopa (VSO) $\quad$ f. *Comeu a sopa, a JOANA (VOS)

Quadro 10: Ordens sentenciais em PB

Fonte: Fernandes (2007: 71)

No tocante ao quadro acima, chamamos a atenção do leitor para as observações de Fernandes (2007: 71) - em trabalho de interface sintático/prosódico. Diferentemente do que ocorre em PE, que aceita seis ordens sentenciais, em PB, apenas as ordens SVO e OSV - ver (10a,d) - com 'sujeito' precedendo o verbo - são aceitas nessa variedade. Fernandes (2007: 71) observa ainda que, a ordem (10d) - OSV - só é possível em PB caso ocorra a inserção de uma pausa após o objeto. Desse modo, como a ordem (10a) SVO - não está associada a nenhuma condição de licenciamento, Fernandes (op cit.) toma esta ordem como a não marcada em PB (a neutra).

Já no que se refere aos verbos inacusativos e estruturas passivas em PB, Fernandes (2007: 72) verifica as mesmas possibilidades de ordem neutra atestadas em PE: tanto a ordem SV quanto VS podem ser obtidas sem qualquer condição associada a elas $^{62}$ :

(11)a. A carta chegou (SV)

b. Chegou a carta (VS)

[O que aconteceu?]

(12)a. As cartas foram entregues (SV)

b. Foram entregues as cartas (VS)

[O que aconteceu?]

Entretanto, em estruturas com verbos inergativos, a única ordem possível para PB é SV, como podemos observar nos exemplos abaixo ${ }^{63}$ :

(13)a. O João trabalhou (SV)

b. * Trabalhou o João (VS)

[O que aconteceu?]

[Quem trabalhou?]

\subsubsection{Considerações sobre a checagem do 'foco' em São Nicolau}

Nesta subseção apresentamos os resultados preliminares do trabalho realizado por Lopes \& Zanoli (2012) a respeito das estratégias de marcação de foco de informação e foco contrastivo da categoria sujeito no cabo-verdiano, na variedade de São Nicolau,

\footnotetext{
${ }^{62}$ Fernandes $(2007,72)$; dados 8, 9, renumerados.

${ }^{63}$ Fernandes (2007: 72); dado (10), renumerado.
} 
utilizando, como parâmetros de comparação, estudos já realizados em PB e PE. Resumidamente, o trabalho aponta que, em São Nicolau, não é possível que o foco seja expresso por outra maneira senão por meio da clivagem. Logo, iniciamos, apresentando um breve resumo acerca da operação “clivagem”.

\section{- CLIVAGEM}

Tomadas como sentenças 'marcadas', assim como as pseudoclivadas, sentenças clivadas são o resultado de uma operação de 'ensanduichamento' de um determinado sintagma da sentença entre uma cópula e um 'que', como podemos observar no exemplo abaixo:

(14) Foi um pastel ${ }_{i}$ que o Eduardo comeu _ $t_{i}$ (e não um sanduíche)

A operação em (14) é realizada para destacar sintaticamente o 'foco', seja para identificar o foco assertivo (informacional) ou o foco contrastivo.

Construções clivadas são vistas na literatura, de modo geral, como estruturas que contêm relativas (ver, entre outros, BRAGA, KATO \& MIOTO, 2009: 283). Entretanto, para Mioto \& Negrão (2007), nem toda construção em que se percebe um elemento ensanduichado entre a cópula e o 'que' contém uma relativa. Os autores tomam as leituras de 'contraste', 'exclusividade' e 'exaustividade' como as principais características das construções clivadas, ao lado da 'leitura especificional'. Em sentenças especificionais há a especificação de um valor a uma variável. Em sentenças clivadas, o constituinte focalizado funciona como esse valor e a sentença introduzida pelo 'que' é a variável, conforme podemos observar no exemplo abaixo:

(15) [É o bolo que] ela está assando valor: o bolo variável: x que ela está assando.

O processo de clivagem gera uma predicação com leitura especificional, caracterizada pela obrigatoriedade de atribuição de um valor a uma variável - cf. Modesto (2001: 33). Assim, na sentença em (15) atribuímos um valor à variável que deve ser, necessariamente, o foco da sentença - o bolo - afinal, ao final da sentença seria possível proferir:

(16) É o bolo que ela está assando (não o frango) 
Desse modo, a relação entre valor/variável presente em sentenças clivadas é a responsável pelas leituras de contraste, visto que o valor atribuído a uma variável faz contraste com todos os outros valores que não foram selecionados, acrescentando ainda uma leitura de exclusividade:

(17) É o Eduardo que gosta da Maria (não o Gilberto)

$\mathrm{Na}$ sentença acima, podemos pressupor que, assim como há um indivíduo que gosta da Maria (pressuposição de existência), há pelo menos uma pessoa que não gosta (pressuposição de exclusividade). Assim, a leitura de exaustividade está em todos os valores.

Voltando a Lopes \& Zanoli (2012), os autores apresentaram formas possíveis ou não para os dois tipos de foco na variedade de São Nicolau: contrastivo e informativo. Desse modo, apontaram os recursos sintáticos das estratégias de marcação de foco no constituinte 'sujeito', ainda que por meio de uma investigação preliminar, tomando as construções clivadas e clivadas invertidas, respectivamente para foco de informação e foco contrastivo. Os autores constataram, como já dito, que, em São Nicolau, a categoria 'sujeito', ao ser focalizada, tem que ser expressa por meio da estrutura de clivagem. No capítulo (4) desta dissertação apresentamos detalhes da análise de Lopes \& Zanoli (2012) e apresentamos uma ampliação à análise desses autores acerca desse tópico.

\subsubsection{Teoria Fonológica}

Dentro do 'referencial teórico' abordado nesta dissertação, apresentamos, a seguir, uma resenha da fonologia entoacional.

\subsubsection{Fonologia entoacional}

De acordo com Ladd (1996), a fonologia entoacional consiste numa abordagem fonológica da estrutura entoacional da língua. Tal abordagem pressupõe que a entoação possui uma organização fonológica - ver também: Pierrehumbert (1980); Beckman \& Pierrehumbert (1986); Pierrehumbert \& Beckman (1988); Hayes \& Lahiri (1991); entre outros.

Segundo Fernandes (2007: 15), um dos principais objetivos da fonologia entoacional é fornecer um aparato descritivo universal para a entoação, tal como propõe o gerativismo. 
A autora (op.cit.) argumenta ainda que, de acordo com a Fonologia Entoacional, um contorno entoacional consiste em uma sequência de unidades discretas: os eventos tonais, que são localmente definidos, constituem blocos de contorno e estão associados a pontos específicos na cadeia segmental. Essas cadeias de eventos tonais são representadas pelo contorno de frequência fundamental (F0).

Geralmente, os eventos tonais mais importantes da cadeia tonal atestados em línguas como PB e PE, por exemplo, são os acentos tonais, associados a sílabas proeminentes, e tons relacionados a fronteiras. Tais eventos podem ser analisados por níveis de altura, alto ( $\mathrm{H}$ - high) e baixo ( $\mathrm{L}$ - low) e podem ser:

Simples, monotonais:

- $\mathrm{L}^{*}$ : vale local;

- $\mathrm{H}^{*}$ : pico local.

Complexos, bitonais:

- $\mathrm{H}^{*}+\mathrm{L}$ : tom alto associado à tônica e curva descendente na pós-tônica;

- $\mathrm{H}+\mathrm{L}^{*}$ : tom alto associado à pretônica e curva descendente da tônica;

- $\quad \mathrm{L}^{*}+\mathrm{H}$ : tom baixo associado à sílaba tônica e ascendência na postônica;

- $\mathrm{L}+\mathrm{H}^{*}$ : tom baixo associado à pretônica e ascendência na tônica.

Já os tons relacionados a fronteiras podem ser os tons de fronteira (boundary tones: $\mathrm{L} \%$ ou $\mathrm{H} \%$ ) e os acentos frasais (phrasal accents: "L-" ou "H-").

Segundo Fernandes (2007: 16), 'de acordo com a Fonologia Entoacional, os eventos tonais são reestruturados conforme relações de constituência e de proeminência definidas pela estrutura prosódica’. Em línguas como o português, por exemplo, a entoação é uma marcação imprescindível para se assinalar o foco. Observemos abaixo a representação, dadas por Fernandes (2007), do o contorno entoacional de uma sentença neutra em PB e a mesma sentença, também em PB, no entanto, com foco prosódico no sujeito ${ }^{64}$,

(18) Sentença Neutra em $\mathrm{PB}^{65}$

\footnotetext{
${ }^{64}$ Chamamos a atenção para a marcação de tons utilizada por Fernandes nas representações acima: Li (L\%) e Lp (L)

${ }^{65}$ Representação (Ia) de Fernandes (2007: 239), renumerado.
} 


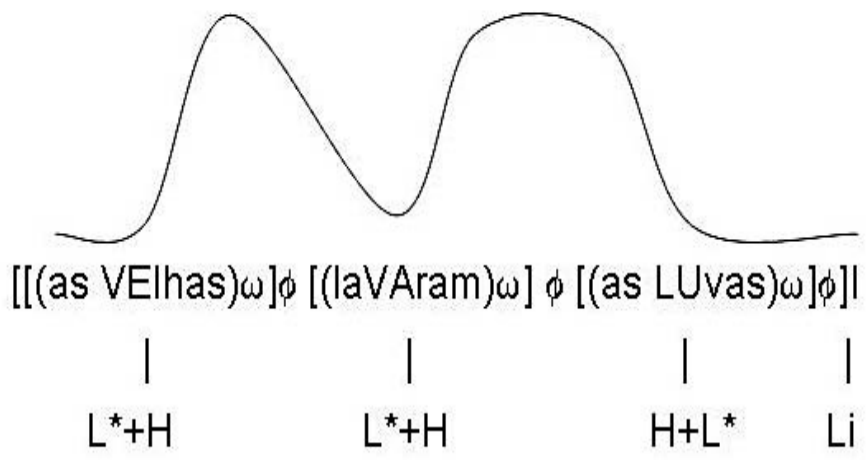

(19) Sentença com Foco Prosódico no PB ${ }^{66}$
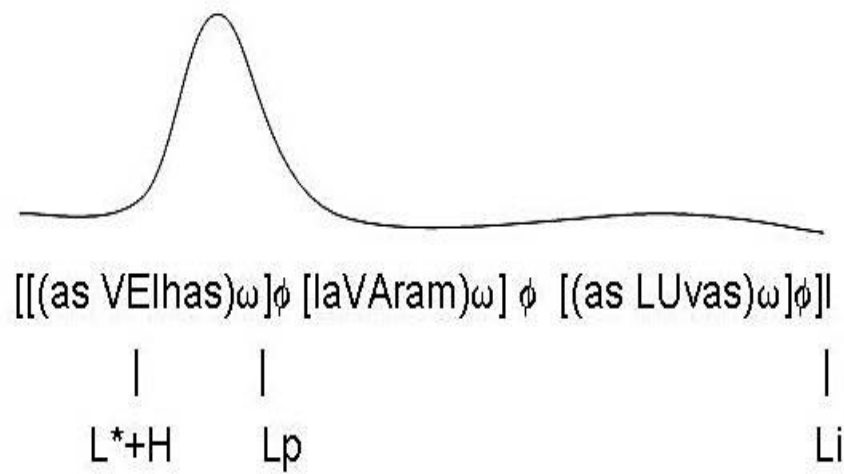

Como podemos observar nos gráficos acima ${ }^{67}$, na sentença com foco, em (19), as principais características encontradas são: acento frasal associado à fronteira final do sintagma que contém o foco e ausência de acentos tonais depois do elemento focalizado.

Fernandes (2007) apresenta também gráficos com as mesmas sentenças em PE, já que sua análise objetiva cotejar o foco nessas duas variedades de português:

(20) Sentença Neutra em PE

\footnotetext{
${ }^{66}$ Representação (IIa) de Fernandes (2007: 240), renumerado.

${ }^{67}$ Os símbolos nos gráficos (1) e (2) são: L (tom baixo); H (tom alto).

${ }^{68}$ Dado (Ib) de Fernandes (2007: 240), renumerado.
} 


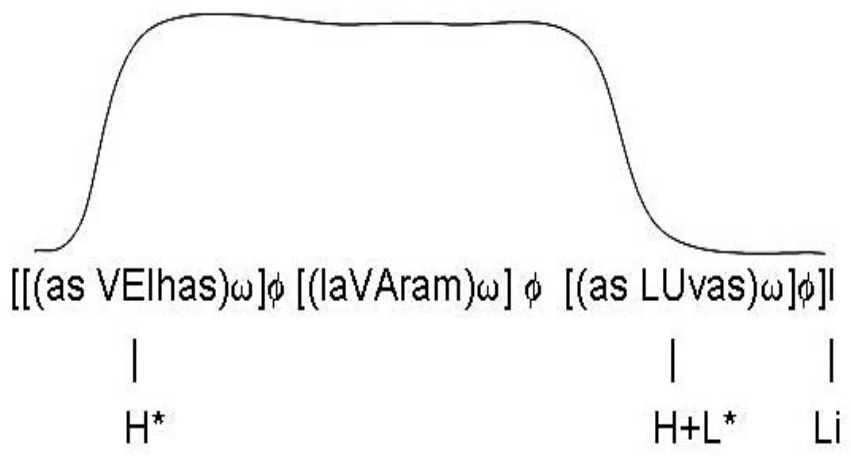

(21) Sentença com Foco Prosódico no PE ${ }^{69}$

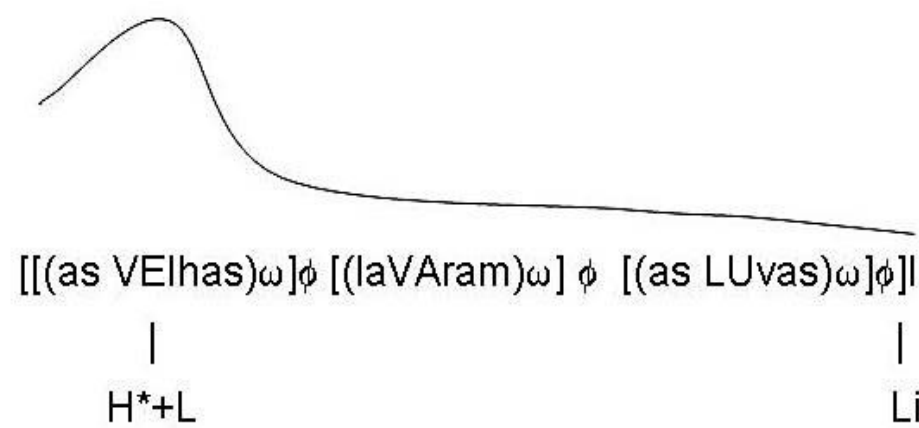

As figuras acima corroboram as pesquisas que apontam para diferenças prosódicas na marcação do foco do sujeito em PE e PB, bem como corroboram diferenças prosódicas nas sentenças neutras nas duas línguas.

Fernandes (2007: 237 -238), apontou para os seguintes resultados:

- acentos tonais associados a $\omega \mathrm{s}$ (palavra fonológica)no contorno das sentenças neutras de $\mathrm{PB}$, e associados às fronteiras inicial e final de I (sintagma entoacional) no contorno entoacional das sentenças neutras de PE;

- contorno entoacional final idêntico nas sentenças neutras de PB e PE (acento tonal $\left.\mathrm{H}+\mathrm{L}^{*}\right)$;

- em 'sentenças com foco prosódico no sujeito' do PE, o acento tonal $\mathrm{H}^{*}+\mathrm{L}$ associado ao sujeito foi consistentemente encontrado nos dados da autora;

- em PB, a autora apontou tanto um acento tonal especial associado ao sujeito focalizado $\left(\mathrm{H}^{*}+\mathrm{L}\right.$ ou $\left.\mathrm{H}+\mathrm{L}^{*}\right)$, que é diferente do acento tonal que o sujeito geralmente porta em contexto neutro $\left(\mathrm{L}^{*}+\mathrm{H}\right)$;

\footnotetext{
${ }^{69}$ Fernandes (2007: 241), dado (IIb), renumerado.
} 
- para o contorno final das 'sentenças com foco prosódico no sujeito', tanto o PB quanto o PE apresentam as mesmas propriedades entoacionais: acento tonal $\mathrm{H}+\mathrm{L}^{*}$ associado a $\omega$ cabeça do último $\varphi$ (sintagma fonológico) de I, seguido por um tom de fronteira $\mathrm{Li}$ associado à fronteira final de $\mathrm{I}$, ou simplesmente tom de fronteira Li associado à fronteira final de I.

\subsection{Referencial metodológico}

Nesta seção, apresentamos a metodologia utilizada para a pesquisa.

\subsubsection{Corpus e metodologia}

A metodologia utilizada para a construção do corpus utilizado nessa dissertação consistiu na elaboração de questionários, na sua aplicação e na análise.

O corpus constitui-se de gravações com falantes nativos do crioulo de Cabo Verde, na variedade da ilha de São Nicolau, tendo por base um questionário controlado a fim de obtermos construções com ocorrências de foco e também para a obtenção de sentenças relativas. Como será melhor explicitado no capítulo (4), sentenças clivadas têm sido analisadas, de modo geral, na literatura, como contendo relativa. No entanto, nesta dissertação, assumimos, corroborando outras propostas, que tais estruturas não contêm relativas. Por tal razão, o ambiente de relativas nos é importante. Ratificamos, neste trabalho - de acordo com Lopes (2012) - que, no cabo-verdiano (variedade de São Nicolau), as sentenças clivadas não contêm relativas.

Para esta dissertação, foram coletados 10 grupos de sentenças contendo construções relativas e clivadas no cabo-verdiano para checar as estratégias de foco do constituinte sujeito.

Como já dito acima, as construções clivadas geralmente são analisadas como contendo relativas. Entretanto, nesta dissertação, seguimos em outra direção, corroborando trabalhos que analisam sentenças clivadas como sentenças que contêm foco. Portanto, as sentenças relativas presentes no corpus são utilizadas como parâmetro de comparação para estruturas que contenham foco.

Voltando ao corpus acima mencionado, cada grupo coletado foi constituído por três tipos de estruturas específicas: (1) relativas; (2) foco informativo; (3) foco contrastivo. A cada uma dessas estruturas oracionais, foi solicitado à(s) informante(s) que as repetissem duas vezes, o que nos dá um total de 60 sentenças. Foi coletado 
também um grupo de sentenças neutras, que, embora pouco utilizadas nesta dissertação, são de grande importância especialmente no tocante à diferenciação entre sentenças neutras e relativas.

Para a coleta dos dados, foram entrevistadas três falantes do sexo feminino, que identificamos pelas siglas CA, MO e TA a fim de salvaguardar suas identidades. As três falantes são nativas da ilha de São Nicolau e alunas de Programas de Graduação da Universidade de São Paulo (USP) e da Pontifíci Universidade Católica de São Paulo (PUC-SP); todas estão na faixa etária entre 20 a 25 anos.

A base para a construção do corpus foi um questionário controlado, elaborado e organizado por Francisco João Lopes em parceria com Maria de Lurdes Zanoli, a fim de se obter construções com ocorrências de foco ${ }^{70}$. Para tal, foram construídas situações contextos a fim de obter as requeridas construções.

- Identificando as falantes no corpus:

Com relação à identificação dos dados no corpus, procederemos da seguinte maneira: (i) primeiramente utilizaremos as siglas apontadas acima (CA, MO, ou TA) para se referir às falantes que proferiram a sentença que está sendo analisada. (ii) em seguida, colocamos o número do grupo do qual foi retirado a sentença em questão (1 a 10); (iii) após, colocamos a letra inicial que identificará o tipo de sentença que está sendo analisada: $\mathbf{R}$ para sentença relativa, $\mathbf{C}$ para sentença com foco contrastivo na categoria sujeito e I para sentenças com foco de informação na categoria sujeito e $\mathbf{N}$ para as sentenças neutras; (iv) na quarta posição de identificação dos dados, colocamos o número que indica a vez que a sentença está sendo proferida (1 ou 2).

Veja o exemplo:

\section{Grupo de sentença}

CA - 1 - C - $2 \longrightarrow$ repetição (segunda repetição)

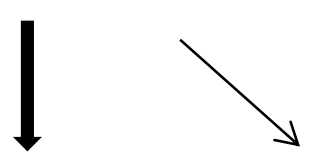

Informante Tipo de sentença (com foco contrastivo)

\footnotetext{
${ }^{70}$ O questionário se encontra em anexo - Apêndice 1: Lopes \& Zanoli (2013).
} 
Logo, no esquema acima, apontamos que, a falante que proferiu a sentença é CA; esta sentença pertence ao grupo 1; a estrutura é foco contrastivo (C) e é a repetição da sentença (2) - ver Apêndice 1.

Em (22), exemplificamos como os dados do corpus serão apresentados:

(22) (Naun) É uns mnininha k’robó-m goeba (CA 1. C. 2)

(Naun) $\mathbf{E}$ uns mnininha $k^{\prime}$ robô- $\mathbf{m}$ goeba

(Naun) COP DET meninas FOC roubar 1.sg. OBJ goiaba

(Não) Foram as meninas que me roubaram goiaba

Cada imagem gerada pelo Praat (ver subseção 3.3 .2 abaixo), no capítulo (4) será também identificada pelo modo acima descrito.

Além dos dados coletados no corpus que se constituem da nossa principal fonte de análise, nesta dissertação, fazemos uso de outros dois tipos de corpus: (i) dados retirados da literatura - que serão referendadas em nota; (ii) dados fornecidos por meio de comunicação pessoal por Francisco João Lopes, que nesta dissertação, são identificados por FJL (c/p). Francisco João Lopes é nativo da ilha de São Nicolau, Cabo Verde, mestre pela Universidade de São Paulo. Atualmente é doutorando pela mesma Instituição.

Após delimitação e transcrição do corpus, passamos à descrição e análise prosódica dos dados, através do uso da ferramenta Praat, e com bases nos pressupostos teóricos da Fonologia Entoacional, para que, desse modo, pudessemos apreender aspectos de interface fonologia/sintaxe e seguir em nossas análises.

\subsubsection{O programa Praat}

O programa Praat foi desenvolvido por Paul Boersma e David Weenink no Instituto de Ciências Fonéticas da Universidade de Amsterdam, em 1992, passando por diversas revisões e atualizações desde então. O Praat, que é um programa de Software Livre, gratuito, baixado livremente na internet, vem sendo um dos programas de análise acústica mais utilizados por pesquisadores na atualidade.

Com versões para sistemas operacionais desde Windows até MacOS ou Linux, é um programa que possibilita a análise, a síntese e a manipulação de segmentos até a melodia dos sons da fala. Além disso, o programa permite a criação de imagens de alta qualidade e precisão como espectogramas, oscilogramas, curvas de pitch, intensidade, duração e outros. 
Porém, o que faz do Praat um dos programas mais utilizados no meio acadêmico é a possibilidade de programar ações repetitivas com parâmetros técnicos previamente definidos. De acordo com Fricke-Matte (2006):

O programa vem com um excelente manual de instruções, com forte ênfase na programação, e com uma ferramenta de histórico de comandos que pode ser acessada pela própria janela de programação (o shell do programa). Assim, qualquer ação que será repetida pode ser simulada uma vez e, a partir dessa simulação, o pesquisador consegue saber os comandos básicos para programar a repetição da ação quantas vezes for necessário.

Desse modo, o Praat se tornou uma ferramenta chave nas pesquisas em ciência da fala devido à grande capacidade de adaptação às necessidades dos usuários. Nessa dissertação utilizaremos a ferramenta Praat para apreender aspectos fonológicos dos dados apresentados, especificamente para analisarmos entoacionalmente as sentenças do cabo-verdiano, variedade de São Nicolau.

Para acesso ao programa ver Fricke-Matte (2006).

\subsection{Síntese do capítulo}

Nesse capítulo, apresentamos o referencial teórico-metodológico utilizado na dissertação.

Primeiramente, abordamos aspectos da categoria foco e apresentamos considerações sobre a checagem dessa categoria em PB, em PE e em São Nicolau. Levamos em consideração aspectos ligados, sobretudo, à ordem, considerando, ainda, questões ligadas à operação "clivagem".

Quanto à fonologia, cerne da teoria abordada na dissertação, adotamos a fonologia entoacional, que, segundo Ladd (1996), consiste numa abordagem da estrutura entoacional da língua. Como visto, tal abordagem pressupõe que a entoação possui uma organização fonológica. A fonologia entoacional fornece um aparato descritivo universal para a entoação.

Ao final, tratamos acerca do referencial metodológico, apresentando o corpus utilizado na dissertação, bem como acerca da metodologia aplicada. Terminamos o capítulo apresentando o Programa Praat, ferramenta utilizada na análise entoacional das sentenças que compõem o corpus. 


\section{CAPÍTULO 4}

\section{PARA UM ALARGAMENTO DA ANÁLISE DA CHECAGEM DE 'FOCO' DA CATEGORIA 'SUJEITO’ NO CABO-VERDIANO DE SÃO NICOLAU}

\subsection{Introdução}

No capítulo anterior, abordamos a respeito das sentenças clivadas. Dissemos, ainda que brevemente, que na literatura, de modo geral, as construções clivadas são tratadas como contendo relativas. Assumimos, no entanto, que, seguimos em outra direção, apontando que nem toda construção contendo um elemento ensanduichado entre a cópula e o morfema 'que' pode ser analisada como contendo relativa. Tal abordagem é significativa para nossa proposta de foco para o cabo-verdiano, variedade de São Nicolau. Essa abordagem, assumimos desde Lopes \& Zanoli (2012) e a ratificamos a partir Lopes (2012).

Desse modo, tendo em vista a hipótese de que nem toda construção clivada contém relativa, nesse capítulo, aprofundamos o estudo da checagem de 'foco' do constituinte ‘sujeito' realizado por Lopes \& Zanoli (2012) - parcialmente resenhado no capítulo anterior - por meio da análise de um corpus maior, submetido à análises entoacionais. Nessa pesquisa, tivemos por meta apontar diferenças e/ou semelhanças entre sentenças com foco contrastivo, informativo e sentenças relativas que contrapõese, portanto, a estruturas focalizadas. Neste capítulo, voltaremos ao estudo de Lopes \& Zanoli (2012) a fim de melhor apresentá-lo e expandir sua análise que pensamos fazêlo, em certo sentido, neste nosso trabalho.

\subsection{Análise das sentenças relativas}

Nesta subseção, com base em um corpus ampliado, retomamos o estudo das sentenças com marcação de foco contrastivo e de informação na variedade de São Nicolau realizadas por Lopes \& Zanoli (2012) a fim de ampliarmos, até onde possível, a análise, como anteriormente apontado. O primeiro grupo de sentenças analisadas foram as relativas, logo as estruturas consideradas sem marcação de foco.

Chamamos a atenção do leitor para o fato de que o corpus de nossa análise recebe identificação específica, que é detalhada no capítulo (3), subseção (3.3.1.). Para 
auxiliarmos o leitor, resumimos as principais abreviaturas: (i) siglas para as informantes: CA, MO, TA, FJL, FJL (c/p); (ii) número do grupo do qual foi retirado a sentença em questão (1 a 10); (iii) letra inicial que identifica o tipo de sentença que está sendo analisada: $\mathbf{R}$ para relativa, $\mathbf{C}$ para foco contrastivo da categoria sujeito, I para foco de informação da categoria sujeito e $\mathbf{N}$ para sentença neutra; (iv) número que indica se é a repetição da sentença (1 ou 2 ).

\subsubsection{Sentenças que contêm relativas: sem marcação de foco}

Antes de abordarmos sentenças que contêm relativas, fazemos aqui uma observação a respeito da análise de Lopes (2012: 102).

Lopes (op cit.), ao analisar sentenças relativas, as denomina: “[...]'sentenças neutras', ou seja, sem marcação de foco”. Lopes \& Zanoli (2012) ratificam a mesma análise.

Como apontado na subseção (3.2.1.1.) do capítulo anterior, atestamos que a ordem 'neutra' ou 'básica' é a menos marcada - (ÂMBAR, 1992: 45). Logo, por ordem menos marcada entende-se uma ordem não (ou menos) associada a alguma condição específica, seja de ordem sintática, prosódica, semântica ou pragmática. Sendo assim, discordamos de Lopes (2012: 102) de que sentenças relativas, embora sem marcação de foco, sejam sentenças neutras.

Chamamos a atenção, portanto, para uma sentença relativa, sem foco, em caboverdiano de São Nicolau:

(1)a. Un musinh k'panhó-b bo bol sei ta korê (MO 2.R.1)

Un munsinh $k^{\prime}$ robó $-b \quad$ goeba sei ta korê

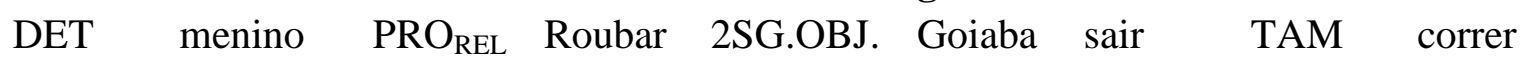
$O$ menino que te roubou goiaba saiu correndo

b. (MO 2.R.1) 


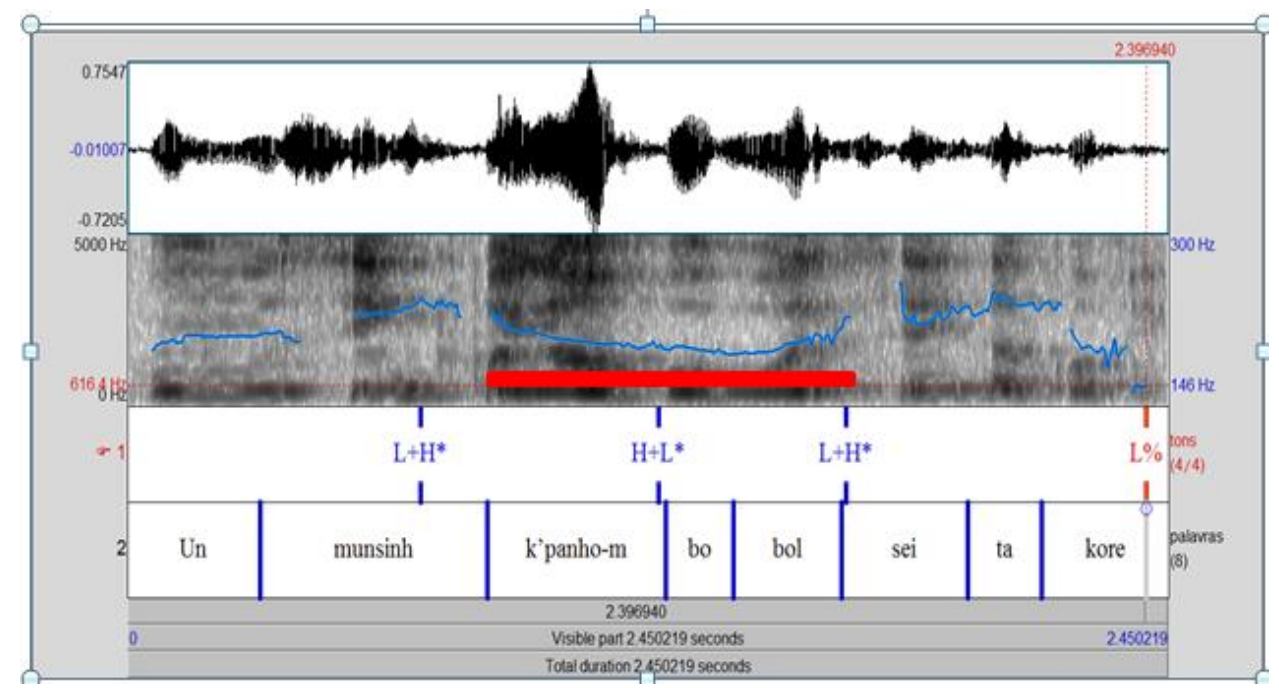

Figura 15: Imagem Praat de uma sentença relativa: MO 2.R.1

Ao considerarmos por ordem menos marcada uma sentença desassociada de uma “condição específica" - no sentido de Âmbar (1992: 45) -, nossa análise prevê (ao contrário da de Lopes (2012: 102)) que sentenças relativas em cabo-verdiano de São Nicolau, como as em (1), não sejam sentenças neutras, embora concordemos com Lopes (2012) de que tais sentenças não atestem foco.

Atente o leitor para a sentença (1b), descrita na figura Praat acima, que apresenta um abaixamento da tessitura entoacional na relativa, marcada pela figura em vermelho. Esse fato prosódico por si demonstra a não neutralidade da oração relativa.

Abaixo, inserimos, portanto, uma sentença que consideramos "neutra" no caboverdiano de São Nicolau: a sentença $(3)^{71}$. Antes, no entanto, apresentamos a sua sentença contexto:

\section{$\underline{\text { Sentença Contexto }}$}

(2) Kin k'torna ben oj? (FJL)

Quem que voltou hoje?

\section{(3)a É uns mnininha k’robó-m goeba (CA 1.N.1)}

$\begin{array}{lllllll}\dot{\mathbf{E}} & \text { uns } & \text { mnininha } & \mathbf{k}^{\prime} & \text { robó } & \mathbf{- m} & \text { goeba } \\ \text { COP } & \text { DET } & \text { meninas } & \text { COMP } & \text { roubar } & \text { 1SG.DAT } & \text { goiaba }\end{array}$

Foram as meninas que me roubaram goiaba.

\footnotetext{
${ }^{71}$ A sentença em (3a) pode ser considerada neutra haja vista que toda ela é focalizada. Senteças como essas são também chamadas de "foco de escopo largo".
} 


\section{b. (CA 1.N.1)}

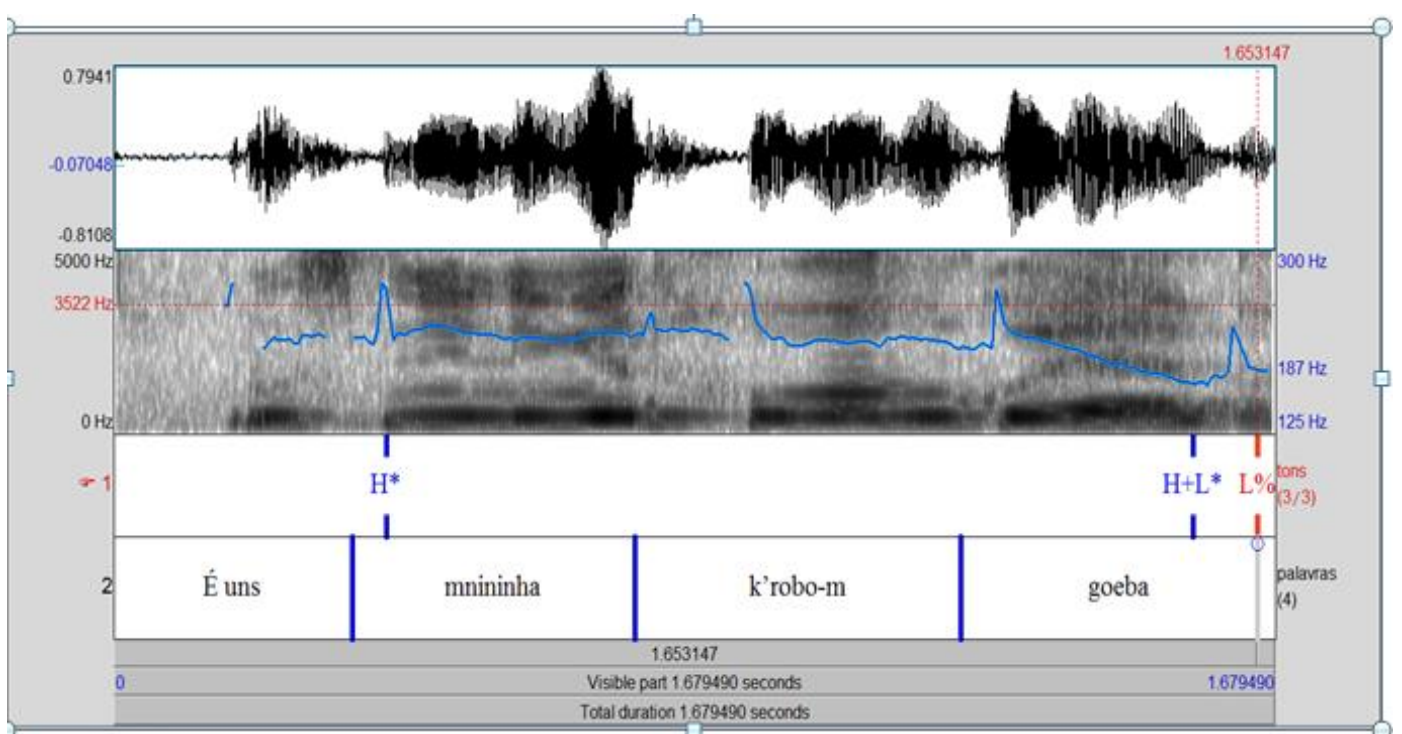

Figura 16: Imagem Praat de uma sentença neutra ou básica

Como podemos abservar, a sentença (3) acima é uma resposta à sentença (2). Na figura (3b), não se atesta nenhuma condição de licenciamento específico - no sentido de Âmbar (1992: 45). Logo, contrastando-se a figura (3b) com a figura (1b) - a relativa pensamos ter corroborado que, em (3b) temos um caso de sentença neutra, diferentemente de (1b).

Ressaltamos que, em nosso trabalho, não incluímos sentenças neutras como objeto de análise. Nosso corpus, como já dito, compõe-se de sentenças relativas, sentenças com foco contrastivo e com foco de informação. Não estamos com isso dizendo que não seria importante termos sentenças neutras no corpus. Dizemos, tão somente, que, para este estudo, sentenças neutras não fazem parte do escopo de nossa análise.

Logo, antes de incluirmos à análise fonológico/prosódica das sentenças relativas, é preciso dizer, sintaticamente, porque aplicamos as relativas ao corpus. Dizemos que o fizemos por duas razões:

(i) seguimos a argumentação de Lopes \& Zanoli (2012) de que, em São Nicolau, o 'foco' da posição 'sujeito' só pode ser marcado por clivagens, logo são estas as únicas construções possíveis de se atestar 'foco' nessa 'variedade'; 
(ii) seguindo Lopes (2012), e outros, consideramos que as clivadas, que tomamos como sentenças focalizadas, não contêm em sua estrutura uma sentença relativa - como o fazem grande parte dos linguistas ao explicarem a estrutura de clivadas - ver, entre outros, Brito \& Duarte (2003). Exemplificamos, por meio de Oliveira (2014: 408), uma estrutura clivada tomada como "contendo relativa"72:

(1)a. Foi [um traBAlho] que o linguista escreveu (Ele não escreveu um livro).

$$
\begin{aligned}
& \text { b. }\left[\text { IP ... foi } \left[S C L [ N P \text { um traBAlho } ] _ { i } \left[S C L \left[C P \text { OP }{ }_{j}\right.\right.\right.\right. \text { que o linguista } \\
& \text { escreveu } \left.\left.\left.\left[{ }_{\mathrm{v}}\right]_{\mathrm{j}}\right]\left[\mathrm{v}_{\mathrm{v}}\right]_{\mathrm{i}}\right] \mathrm{i}_{\mathrm{i}}={ }_{\mathrm{j}}\right)^{73}
\end{aligned}
$$

Diferentemente de linguistas como Brito \& Duarte (2003), e outros, assumimos, em conjunto com outro grupo de linguistas que há "[...] um conjunto de evidências de natureza prosódica, sintática e semântica em favor da tese de que o CP de uma sentença clivada não é um CP relativo." - Mioto \& Negrão (2008: 182). Ao final, apresentamos nossa análise sintática de estrutura clivada em cabo-verdiano de São Nicolau, assumindo a proposta que se vê em Mioto \& Negrão (2008: 182).

Uma das evidências, apontadas por Mioto \& Negrão (op.cit) de que o CP de uma clivada não é relativo (portanto, essas 'estruturas' não são parte uma da outra), são atestadas em cabo-verdiano de São Nicolau, por meio dos experimentos em Praat, que apontam as diferenças entre clivadas e relativas na língua.

O primeiro grupo de sentenças, alvo de nossa análise, foi, portanto, o grupo de estruturas contendo relativas.

O grupo das relativas é composto por dez sentenças, como já dito no capítulo (3), proferidas duas vezes cada sentença por cada uma das três falantes. Abaixo, segue o quadro com as sentenças analisadas.

\footnotetext{
${ }^{72}$ Oliveira (2014: 4c-d, renumerados). Utulizamos a tradução.

${ }^{73}$ A estrutura oferecida por Oliveira (2014: 408) para a sentence clivada é baseada em Brito \& Duarte (2003: 689; exemplo (1b)). Em geral, assume-se, incluindo Brito \& Duarte (2003), que cada estrutura clivada ocupa a posição ‘sujeito' de uma “pequena oração" - small clause - e é ligada por um operador. Esse operador (Op) pode ser um pronome relativo ou um operador nulo que se liga ao 'foco' na sentença clivada (que contém essa relative) - ver ainda Braga, Kato \& Mioto (2009: 283).
} 


\begin{tabular}{|c|c|}
\hline Grupo & Sentença \\
\hline 1 & $\begin{array}{l}\text { Uns mnininha k'robô-m goeba torna bem oj } \\
\text { "Umas meninas que me roubaram goiaba voltaram hoje" }\end{array}$ \\
\hline 2 & $\begin{array}{l}\text { Un musinh k'panhó-b bo bol sei ta korê } \\
\text { "Um rapaz que te apanhou seu bolo saiu correndo" }\end{array}$ \\
\hline 3 & $\begin{array}{l}\text { Ôm k’ta papia d'más ka é d'fiansa } \\
\text { "Homem que fala demais não é de confiança" }\end{array}$ \\
\hline 4 & $\begin{array}{l}\text { Ôz k'ta kmê midj ten forsa } \\
\text { "Asno que come milho tem força" }\end{array}$ \\
\hline 5 & $\begin{array}{l}\text { Ôm k'ta pega na nxada deve dôd valor } \\
\text { "Homem que pega na enxada deve-se dar valor" }\end{array}$ \\
\hline 6 & $\begin{array}{l}\text { Pai k' ta korriji fidj ta ivita problema } \\
\text { "Pai que corrige filho evita problema" }\end{array}$ \\
\hline 7 & $\begin{array}{l}\text { Kmida k'ta na txon é d'gôt má katxor } \\
\text { "Comida que está no chão é do gato e do cachorro" }\end{array}$ \\
\hline 8 & $\begin{array}{l}\text { Gôt k'ta roba na panela ta dtxa psoa doid } \\
\text { "Gato que rouba na panela deixa a pessoa doida" }\end{array}$ \\
\hline 9 & $\begin{array}{l}\text { Un tia k’N ka ta konxê dja ont na Saninklau } \\
\text { "Uma tia que eu não conhecia chegou ontem em São Nicolau" }\end{array}$ \\
\hline 10 & $\begin{array}{l}\text { Un môss k'ben d'Brazil aont, purguntó-m pa bó } \\
\text { "Um moço que cgegou do Brasil ontem, me perguntou de você" }\end{array}$ \\
\hline
\end{tabular}

Quadro 11: Sentenças relativas analisadas

Fonte: Lopes \& Zanoli (2013)

Abaixo apresentamos imagens Praat de duas sentenças que contêm relativas:

(4)a Uns mnininha k'robó-m goeba torna ben oj (MO 1.R.2)

$\begin{array}{lllllllll}\text { Uns } & \text { minininha } & \mathbf{k}^{\prime} & \text { Robó } & \mathbf{M} & \text { goeba } & \text { torna } & \text { ben } & \text { oj } \\ \text { DET } & \text { meninas } & \text { PRO }_{\text {REL }} & \text { Roubar } & \text { 1.SG.DAT } & \text { goiaba } & \text { voltar } & \text { vir } & \text { hoje }\end{array}$
As meninas que me roubaram goiaba voltaram hoje.

b. (MO-1-R-2)

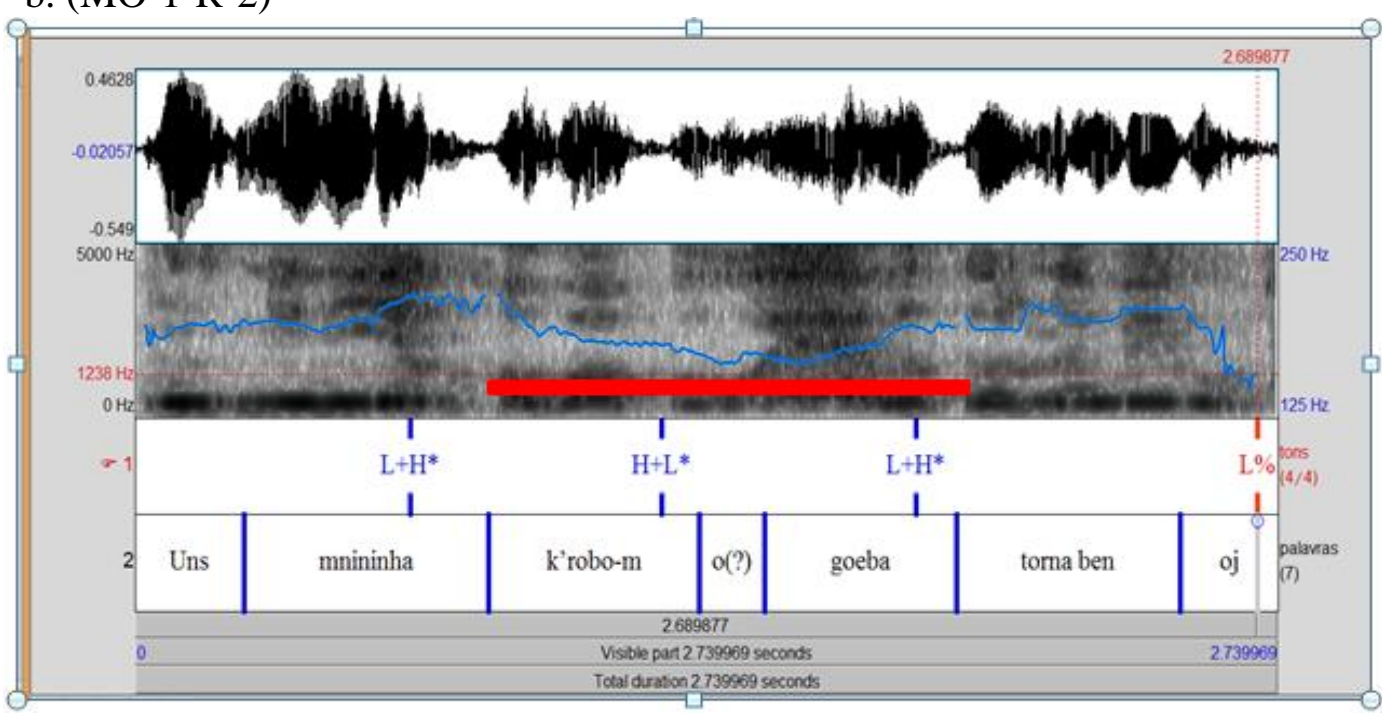

Figura 17: Imagem Praat de sentença relativa 
A seguir apresentamos outra sentença relativa:

(5)a Ôz k’ta kmê midj ten forsa (CA-4-R-2)

$\begin{array}{llllll}\hat{O} z & k^{\prime} & \text { Ta } & \text { Kmê } & \text { Midj ten } & \text { Forsa }\end{array}$

Asno PRO $_{\text {ReL }} \mathrm{HAB}$ comer Milho Ter força

$O$ asno que come milho tem força.

b. (CA- 4-R-2)

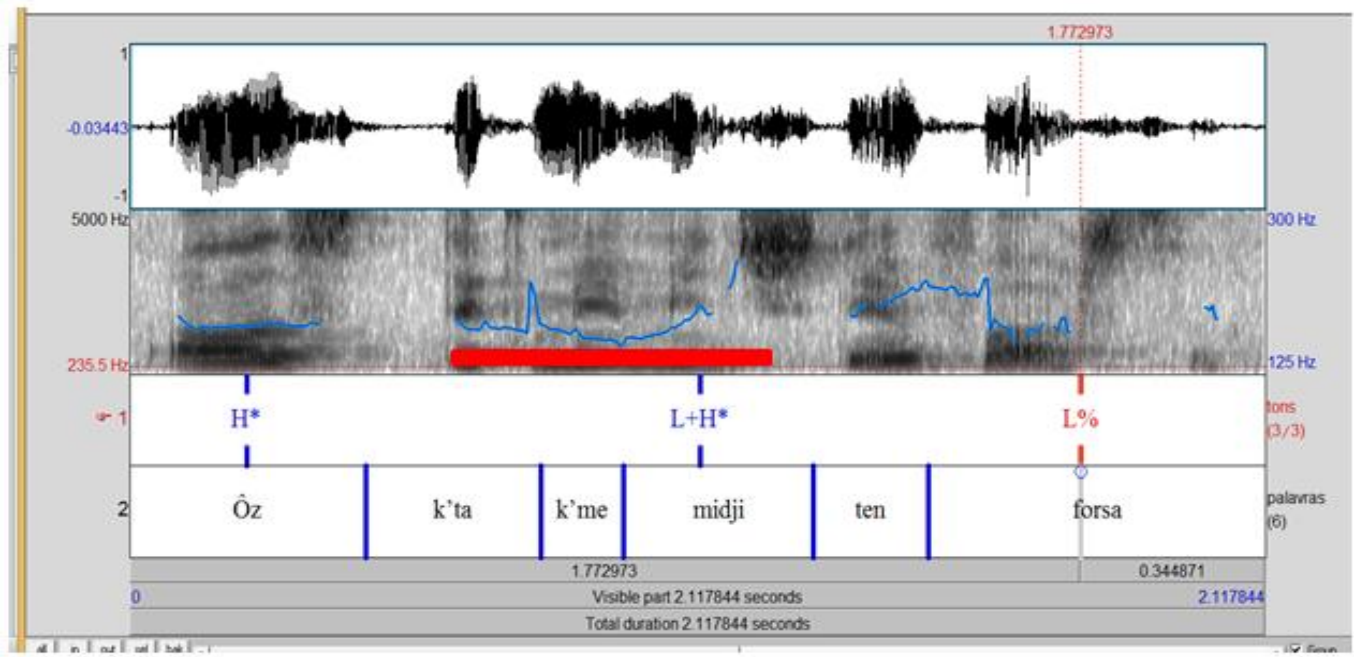

Figura 18: Imagem Praat de sentença relativa

Como observamos nas imagens Praat em (4b) e (5b), em sentenças contendo construções relativas, um padrão comum é um abaixamento da tessitura do contorno entoacional, como mostra a linha em vermelho, marcando a posição das orações relativas nas sentenças [k' robô- m goeba] "que me roubaram goiaba" (4a-b) e [k' ta kmê midj] "que come milho" (5a-b). Além disso, notamos, também, que, logo após as relativas, há a elevação da tessitura entoacional. Tal fenômeno parece ser recorrente em São Nicolau no que diz respeito às sentenças relativas, corroborando estudos realizados, até o momento, para a variedade em questão - ver Lopes \& Zanoli (2012) e Lopes (2012: capítulo 6).

Logo, como características entoacionais gerais encontradas nas análises realizadas com sentenças relativas, notam-se:

(i) ausência de elevação da tessitura do contorno entoacional - que será relevante para a marcação de foco (como atestaremos mais adiante), marcada por um achatamento (em escala de F0) da gama de variação da curva entoacional (pitch range), se comparado ao trecho antecedente; 
(i) não predominância exclusiva de nenhum bitonal na relativa; ou seja, não há nenhum padrão tonal que marque a sentença relativa. Os bitonais mais recorrentes são decrescentes - com descendência na tônica $(\mathrm{H}+\mathrm{L} *)$ e crescente - com ascendência na tônica $\left(\mathrm{L}+\mathrm{H}^{*}\right)$. Abaixo apresentamos um quadro com os tons encontrados nas relativas e o número de ocorrências:

\begin{tabular}{|l|l|}
\hline Tom & Número de ocorrências \\
\hline $\mathrm{H}+\mathrm{L}^{*}$ & 27 \\
\hline $\mathrm{L}+\mathrm{H}^{*}$ & 29 \\
\hline $\mathrm{H}^{*}+\mathrm{L}$ & 3 \\
\hline $\mathrm{H}$ & 1 \\
\hline $\mathrm{L}^{*}+\mathrm{H}$ & 1 \\
\hline
\end{tabular}

Quadro 12: Número de ocorrências tonais em sentenças relativas

(ii) $\mathrm{Na}$ sentença imediatamente posterior à relativa, o tom mais recorrente encontrado foi o ascendente - com ascendência na tônica, evidenciando a elevação de tessitura após a descendência na relativa. Observe o quadro abaixo:

\begin{tabular}{|l|l|}
\hline Tom & Número de Ocorrência \\
\hline $\mathrm{H}^{*}+\mathrm{L}$ & 12 \\
\hline $\mathrm{L}^{+} \mathrm{H}^{*}$ & 30 \\
\hline $\mathrm{H}+\mathrm{L}^{*}$ & 14 \\
\hline $\mathrm{H}^{*}$ & 2 \\
\hline $\mathrm{L}^{*}+\mathrm{H}$ & 2 \\
\hline
\end{tabular}

Quadro 13: Número de ocorrências tonais em sentenças imediatamente posterior à relativa

Chamamos a atenção para o caso do elemento k' nas sentenças relativas. Lopes (2012: capítulo 3), ao descrever a natureza dos elementos introdutores de orações relativas, na variedade da língua cabo-verdiana falada na ilha de São Nicolau, segue a proposta de De Vries (2002). Logo, para Lopes (op cit.), em sentenças como (4) e (5) acima, o k' é tratado como 'complementizador relativo'. Assim, a classe dos pronomes relativos distingue-se, para o autor, da dos relativizadores, que não são tratados como 
pronomes, mas sim como complementizadores (C), e mais especificamente, como complementizadores relativos (COMPREL).

Diferentemente, Oliveira, Jorge \& Lopes (2013) demonstram uma ambiguidade teórica apontada em Lopes (2012) no tocante à nomenclatura/categorização que utiliza, a partir de De Vries (2002), ao tratar o k’ das relativas - como em sentenças em (4) e (5) - como 'complementizador relativo'. Para Oliveira, Jorge \& Lopes (2013), ou um elemento é complementizador ou é pronome/relativizador.

Em seu estudo, Oliveira, Jorge \& Lopes (2013), revisitam parte do estudo de Lopes (2012) no tocante à análise da partícula k’ como complementizador relativo

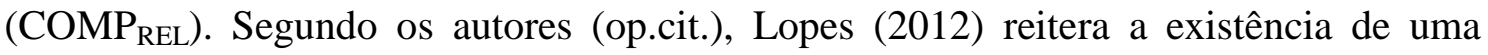
ambiguidade teórica relacionada ao termo complementizador relativo $\left(\mathrm{COMP}_{\mathrm{REL}}\right)$ que se vê em De Vries (2002); este autor, ao considerar todos os elementos QUcomplementizadores, denominando-os de "complementizadores relativos", insere os "pronomes relativos" no conjunto de elementos QU. Tal fato leva Oliveira, Jorge \& Lopes (2013) a discordarem do termo $\mathrm{COMP}_{\mathrm{REL}}$ atribuído à partícula $\mathbf{k}$ ' por Lopes (2012) e a proporem que esta partícula, em relativas em CSN, seja considerada um pronome relativo $\left(\mathrm{PRO}_{\mathrm{REL}}\right)$.

Nesta dissertação, ratificamos a proposta dos autores (op.cit) de que o k' das relativas, em exemplos como (4) e (5) acima, seja considerado pronome relativo $\left(\mathrm{PRO}_{\mathrm{REL}}\right)$ na língua.

Ao final desta seção, ratificamos análises anteriores de que sentenças relativas não contêm foco.

\subsection{Análise das sentenças clivadas e a checagem de foco da categoria 'sujeito'}

Como resenhado no capítulo (3), subseção (3.2.1.2.), o trabalho de Lopes \& Zanoli (2012) apontou que, em cabo-verdiano, variedade de São Nicolau, a categoria 'sujeito' só pode receber o traço 'foco' por meio de estrutura clivada. Logo, diferentemente do que apresentamos como característica do PE, que atesta sujeito posposto - capítulo (3), subseção (3.2.1.2.) - em cabo-verdiano, tal como em PB, essa possibilidade não se confirma. Observe os dados a seguir:

(6)a Kin k' leba mala? (FJL (c/p))

b. \#Maria leba mala

c. *Leba mala Maria

d. Maria é k' leba mala
"Quem levou a mala?"

"A Maria levou a mala"

"Levou a mala a Maria"

"Foi Maria que levou a mala" 
As sentenças (6b) e (6c) são sentenças simples que visam responder a sentença-contexto em (6a) para obtenção de foco. Atente que, em (6b), a sentença resposta é pragmaticamente anômala, ou seja, é gramatical semanticamente, se tomada como uma sentença neutra. Nesse caso, teríamos uma interpretação de partícula TMA (morfema zero) e a sentença no passado - a ordem seria, portanto, SVO na língua, haja vista que a focalização em cabo-verdiano se dá apenas com sentenças clivadas. No entanto, em (6b), "Maria", tomada como elemento focalizado, não pode ser produzida na língua. Em (6c), a sentença resposta é agramatical, pois em cabo-verdiano não se permite a ordem VOS como atestada nessa sentença. Logo, como se percebe, a única sentença que responde pragmaticamente ao contexto de pergunta-foco a (6a) é a sentença (6d), uma estrutura clivada, ratificando o estudo de Lopes \& Zanoli (2012).

Abaixo, seguem outros dados que ratificam a análise acima:

(7)a Kin $\underline{\text { k}}$ jga ont? (FJL (c/p)) "Quem chegou ontem?"
b. \#João jga ont
"O João chegou ontem"
c. *Jga ont João
"Chegou ontem o João"
d. João é k' jga ont
"Foi o João que chegou ontem"

Como apontado acima, somente a sentença (7d) responde a (7a) em contexto de foco. Observe-se, portanto que trata-se de uma sentença clivada.

\subsubsection{A tipologia do 'foco' em São Nicolau}

Nossa análise ratifica a tipologia de foco atestada em Lopes \& Zanoli (2012) para o cabo-verdiano de São Nicolau: foco contrastivo e de informação. No entanto, apresentamos um alargamento daquele estudo, apresentando análise entoacional de 10 grupos de sentenças que descrevemos a seguir.

Passamos primeiramente à análise da checagem do 'foco contrastivo' do constituinte sujeito - como já apontado, a análise se deu por meio de dez sentenças, proferidas duas vezes cada uma por cada uma das três falantes. Abaixo, segue o quadro com as sentenças analisadas. 


\begin{tabular}{|c|c|}
\hline Grupo & Sentenças \\
\hline 1 & $\begin{array}{l}\text { (Naun) É uns mnininha k’robó-m goeba } \\
\text { "(Não) Foram umas meninas que me roubaram goiaba" }\end{array}$ \\
\hline 2 & $\begin{array}{l}\text { Naun, un munsinh é k’panhó-b bo bol } \\
\text { "Não, um rapaz é que te apanhou seu bolo" }\end{array}$ \\
\hline 3 & $\begin{array}{l}\text { Naun, ôm é k’ta papia d'más } \\
\text { "Não, homem é que fala demais" }\end{array}$ \\
\hline 4 & $\begin{array}{l}\text { Naun, ôz é k’ta kmê midj } \\
\text { "Não, asno é que come milho" }\end{array}$ \\
\hline 5 & $\begin{array}{l}\text { (Naun) ôm é k’ta pega na nxada } \\
\text { "(Não) homem é que pega na enxada" }\end{array}$ \\
\hline 6 & $\begin{array}{l}\text { Pai é k’ta korriji fidj } \\
\text { "Pai é que corrige filho" }\end{array}$ \\
\hline 7 & $\begin{array}{l}\text { ( Naun), kmida é k'sta na txon } \\
\text { "(Não), comida é que está no chão" }\end{array}$ \\
\hline 8 & $\begin{array}{l}\text { (Naun), gôt é k’ta roba na panela } \\
\text { "(Não), gato é que rouba na panela" }\end{array}$ \\
\hline 9 & $\begin{array}{l}\text { (Naun), un tia é k’N ka ta konxê } \\
\text { "(Não), uma tia é que eu não conheço" }\end{array}$ \\
\hline 10 & $\begin{array}{l}\text { (Naun), un moss é k'ben d'Brazil aont } \\
\text { (Não), um moço é que chegou do Brasil ontem" }\end{array}$ \\
\hline
\end{tabular}

Quadro 14: Sentenças com 'foco contrastivo'

Fonte: Lopes \& Zanoli (2013)

A seguir apresentamos duas sentenças como 'foco contrastivo', seguidas de suas imagens Praat (e antecedidas de suas respectivas sentenças-contexto):

$\underline{\text { Sentença-Contexto }}$

(8) Ont bo faló- m ma uns munsinh robó- b goeba, Ontem 2sg falar 1sg.OBJ TAM DET meninos roubar 2sg.OBJ goiaba é dvera, ka é? (FJL)

COP verdade NEG COP

"Ontem você me falou que uns meninos te roubaram goiaba, é verdade, não é?"

$\underline{\text { Foco Contrastivo }}$

(9)a. (Naun) É uns mnininha k'robó-m goeba (CA-1-C-1)

(Naun) $\quad \hat{E}$ uns mnininha $k^{\prime}$ robô- $m$ goeba

(Naun) COP DET meninas FOC roubar 1.sg.OBJ goiaba

(Não) Foram umas meninas que me roubaram goiaba

A seguir, apresentamos as imagens geradas pela ferramenta Praat. 
b. (CA-1-C-1)

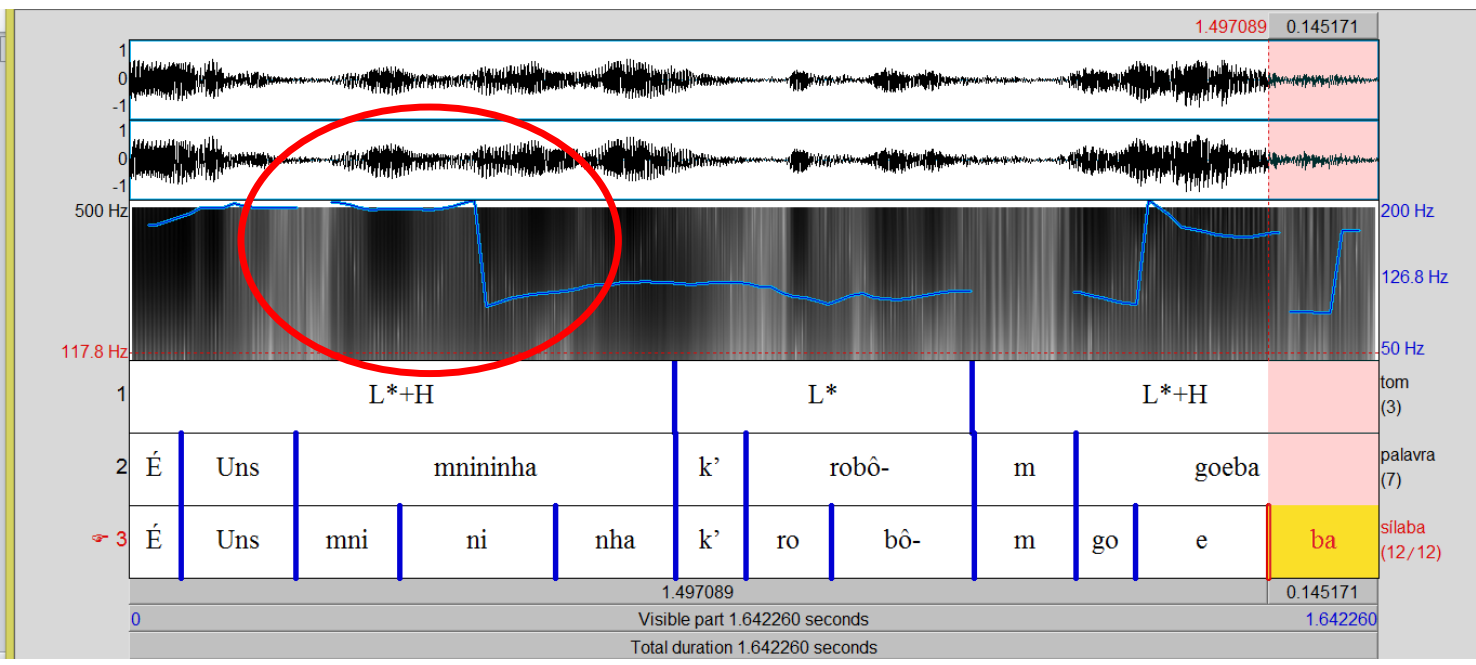

Figura 19: Imagem Praat - 'foco contrastivo'

Sentença-Contexto

(10) Es faló-m ma na Saninklau oj in dia fidj é k'ta korriji pai, é devera? (FJL)

"Me falaram que em São Nicolau hoje em dia os filhos é que corrigem os pais, é verdade?"

$\underline{\text { Foco Contrastivo }}$

(11)a. Pai é k’ta korriji fidj (CA- 6.C.2)

\begin{tabular}{lcllll} 
Pai & $\mathbf{E}$ & $\mathbf{k}^{\prime}$ & Ta & Korriji & Fidj \\
Pai & COP & FOC & HAB & corrigir & filho \\
\multicolumn{2}{l}{ O pai é que corrige } & o filho & & &
\end{tabular}

b. (CA- 6.C.2)

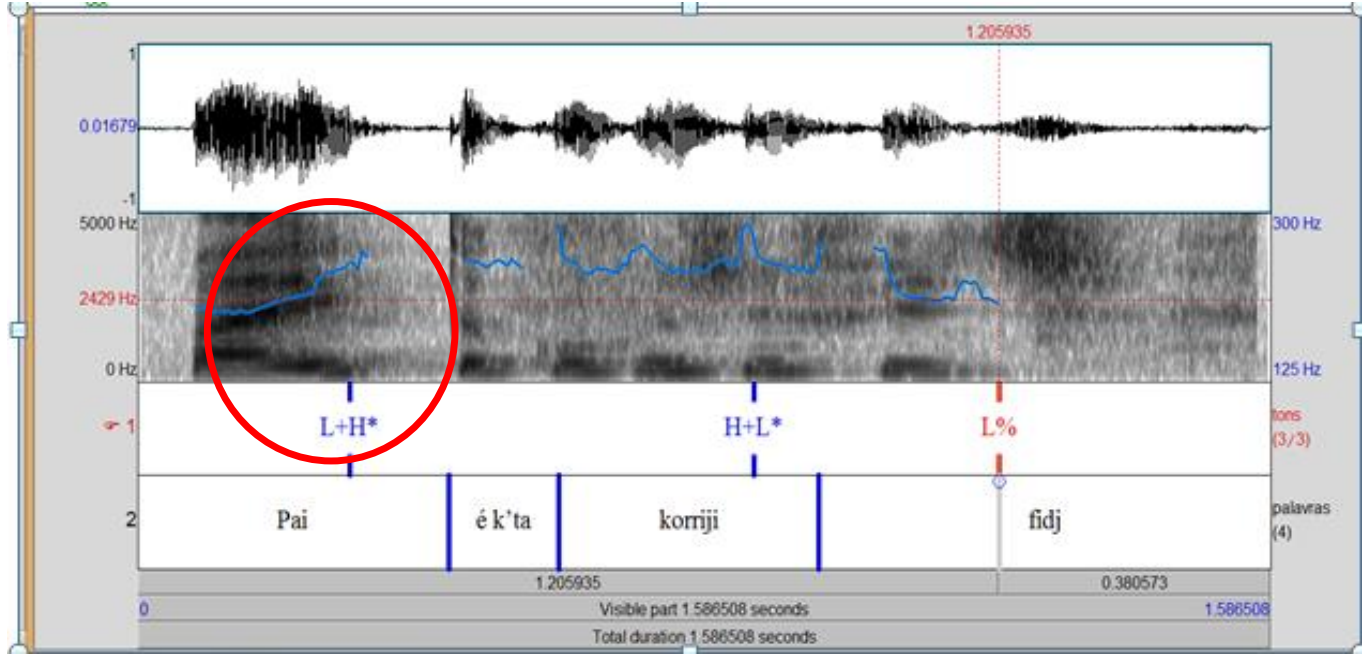

Figura 20: Imagem Praat - checagem foco contrastivo: CA 6-C-2 
Sentenças como as apresentadas em (9) e (11) são consideradas clivadas na língua e apresentam, como já mencionado, 'foco contrastivo'. Sintaticamente, há um elemento ensanduichado entre a cópula e o elemento k' (que): em (9), o constituinte uns mnininha, 'umas meninas'; em (11), o constituinte pai, 'pai'. Fonologicamente, atestase uma elevação da tessitura entoacional, com um acento tonal associado à sílaba tônica do sujeito focalizado, nesses constituintes "ensanduichados", que, em termos sintáticos, também recebem marcação de caso nominativo ${ }^{74}$. Tal elevação é bastante relevante para marcação de foco na língua.

Logo, no que diz respeito à fonologia entoacional, as características gerais atestadas no 'foco contrastivo' em São Nicolau como em (9b) e (11b) são:

(i) predominância do bitonal crescente $\mathrm{L}+\mathrm{H}^{*}$, associado ao constituinte focalizado ('sujeito') uns mnininha 'umas meninas'. Note que essa predominância bitonal crescente $\mathrm{L}+\mathrm{H}^{*}$ diferencia as sentenças com 'foco contrastivo' na língua das estruturas relativas, em que não são observadas predominância de nenhum bitonal;

(ii) tom de fronteira $\mathrm{L} \%$ associado opcionalmente à fronteira direita da frase entoacional.

Segundo o enfoque fonológico, Fernandes (2007: 33) nos chama a atenção para o fato de que constituintes focalizados em algumas línguas, como o PE, por exemplo, (mas não o PB) portam um tipo de acento específico. Esse é o caso do bitonal $\mathrm{L}+\mathrm{H}^{*}$, atestado no 'foco contrastivo' em São Nicolau, como apresentamos no quadro abaixo por meio de 59 ocorrências, das 60 sentenças totais analisadas para esse tipo de foco:

\begin{tabular}{|l|l|}
\hline Tom & Número de ocorrência \\
\hline $\mathrm{L}+\mathrm{H}^{*}$ & 59 \\
\hline $\mathrm{H}^{*}+\mathrm{L}$ & 1 \\
\hline
\end{tabular}

Quadro 15: Número de ocorrências tonais com foco contrastivo do constituinte sujeito

Lopes \& Zanoli (2012) apontam em seu trabalho resultados de testes que visam mostrar quais os tipos de clivagem possíveis para 'foco contrastivo' em São Nicolau. Importante ressaltar que estes testes foram realizados a partir da intuição de um único falante nativo: (FJL). Abaixo, retomamos o quadro de Lopes \& Zanoli (2012) a partir

\footnotetext{
${ }^{74}$ Em outras palavras, estamos assumindo que tais elementos, no Modelo de Princípios e Parâmetros, checa Caso Nominativo na posição [Spec, IP], posição "sujeito", e move-se para a posição [FocP] no Sintagma Complementizador expandido - ver Rizzi (1997), (2002) no capítulo (3).
} 
de uma sentença contexto aplicada a ele:

Sentença-Contexto

(12) Anton na Saninklau ta falód ma jent mdjer ta papia d'más, é dvera? (FJL)

“Então, em São Nicolau se diz que as mulheres falam demais, é verdade?"

\begin{tabular}{|l|l|}
\hline a. Naun, ôm é k’ta papia d'más & "Não, HOMEM é que fala demais" \\
\hline b. * (Naun), ÔM ta papia d'más & "Não, HOMEM fala demais" \\
\hline c. *(Naun), ÔM k'ta papia d'más & "Não, HOMEM que fala demais" \\
\hline d. (Naun), é ÔM k’ta papia d'más & "Não, é HOMEM que fala demais" \\
\hline e. (Naun), é ÔM & "Não, é HOMEM" \\
\hline f. (Naun), é ÔM é k’ta papia d'más & "Não, é HOMEM é que fala demais" \\
\hline g. (Naun), kin k'ta papia d'más é ÔM & "Não, quem que fala demais é HOMEM" \\
\hline h.*(Naun), é ÔM kin k'ta papia d'más & "Não, é HOMEM quem que fala demais" \\
\hline
\end{tabular}

Quadro 16: Tipos de clivagens possíveis para ‘foco contrastivo’ em São Nicolau

Fonte: Lopes \& Zanoli (2013)

Lopes \& Zanoli (2012) observaram que a construção do tipo clivada invertida, como em (13a), (NP focalizado ôm "homem" + cópula é "ser" + marcador de foco k' "que") dispara sempre uma leitura de contrastividade, sendo esta a forma assumida como default para checagem de 'foco contrastivo' do constituinte 'sujeito' na variedade de São Nicolau. Os outros tipos de clivagem, segundo os autores, podem ocorrer, porém, não com frequência Os autores, portanto, não exemplificam quais são essas outras "formas".

Em nossa análise, corroboramos a estrutura "clivagem invertida" como a em (13 a) atestada por Lopes \& Zanoli (2012) como bastante recorrente na marcação do 'foco contrastivo' do constituinte sujeito. Entretanto outras formas foram atestadas, inclusive a dupla cópula, como veremos no quadro abaixo: 


\begin{tabular}{|c|c|c|}
\hline Grupo & Sentenças & Ocorrências \\
\hline 1 & $\begin{array}{l}\text { (Naun) É uns mnininha k'robó-m goeba } \\
\text { (Não) foram umas meninas que me roubaram goiaba }\end{array}$ & 2 \\
\hline 1 & $\begin{array}{l}\text { Uns mnininha é k'robo-m goeba } \\
\text { Umas menina é que me roubaram goiaba }\end{array}$ & 4 \\
\hline 2 & $\begin{array}{l}\text { Naun, un munsinh é k’panhó-b bo bol } \\
\text { Não, um rapaz é que te apanhou seu bolo }\end{array}$ & 4 \\
\hline 2 & $\begin{array}{l}\text { Naun, É um munsinh é k'panho-b bo bol } \\
\text { Não, é um rapaz é que te apanhou seu bolo }\end{array}$ & 2 \\
\hline 3 & $\begin{array}{l}\text { Naun, ôm é k'ta papia d'más } \\
\text { Não, homem é que fala demais }\end{array}$ & 6 \\
\hline 4 & $\begin{array}{l}\text { Naun, ôz é k’ta kmê midj } \\
\text { Não, asno é que come milho }\end{array}$ & 6 \\
\hline 5 & $\begin{array}{l}\text { Naun, ôz é k’ta kmê midj } \\
\text { Não, asno é que come milho }\end{array}$ & 6 \\
\hline 6 & $\begin{array}{l}\text { Pai é k’ta korriji fidj } \\
\text { Pai é que corrige filho }\end{array}$ & 6 \\
\hline 7 & $\begin{array}{l}\text { (Naun), kmida é k'sta na txon } \\
\text { (Não), comida é que está no chão }\end{array}$ & 6 \\
\hline 8 & $\begin{array}{l}\text { (Naun), gôt é k’ta roba na panela } \\
\text { (Não), gato é que rouba na panela }\end{array}$ & 6 \\
\hline 9 & $\begin{array}{l}\text { (Naun), un tia é k’N ka ta konxê } \\
\text { (Não), uma tia é que não conheço }\end{array}$ & 5 \\
\hline 9 & $\begin{array}{l}\text { É um tia k’N ka ta konxê } \\
\text { É uma tia que não conheço }\end{array}$ & 1 \\
\hline 10 & $\begin{array}{l}\text { (Naun), un moss é k'ben d'Brazil aont } \\
\text { (Não), um moço que chegou do Brasil ontem }\end{array}$ & 6 \\
\hline
\end{tabular}

Quadro 17: Tipos de Clivagens em sentenças com 'foco contrastivo' - análise dessa pesquisa

Observamos que, na maioria das ocorrências apontadas no quadro em (19) o tipo preferencial de clivagem para checagem do 'foco contrastivo' da posição 'sujeito' é a “invertida"- ver, por exemplo, as sentenças do grupo 3. No entanto, atestam-se, ainda, os tipos: "clivagem canônica" -ver grupo 1 -; clivada com dupla cópula - grupo 2.

Após analisarmos o 'foco contrastivo' da posição sujeito, passamos à análise entoacional das sentenças com 'foco informacional' desse mesmo elemento na língua. Os grupos de sentenças analisadas para esse tipo de foco são apresentados abaixo:

\begin{tabular}{|c|c|}
\hline Grupo & Sentenças \\
\hline 1 & $\begin{array}{l}\text { É uns mnininha k'robó-m goeba "foram as meninas que me roubaram } \\
\text { goiaba }\end{array}$ \\
\hline 2 & É un munsinh k'panhó-b bo bol "foi um rapaz que apanhou o bolo" \\
\hline 3 & É ôm k'ta papia d'más “é homem que fala demais" \\
\hline
\end{tabular}




\begin{tabular}{|c|c|}
\hline 4 & Ôz é k’ta kmê midj "asno é que come milho" \\
\hline 5 & É ôm k'ta pega na nxada "homem é que pega na enxada" \\
\hline 6 & É pai k’ta korriji fidj “é pai que corrige filho" \\
\hline 7 & É kmida k’ta na txon “é comida que está no chão" \\
\hline 8 & É gôt k’ta roba na panela "é gato que rouba na panela" \\
\hline 9 & É un tia k’N ka ta konxê "é uma tia que eu não conheço" \\
\hline 10 & $\begin{array}{l}\text { É un moss k'ben d'Brazil aont 'é um moço que chegou do Brasil } \\
\text { ontem” }\end{array}$ \\
\hline
\end{tabular}

Quadro 18: sentenças clivadas com 'foco informacional'

Fonte: Lopes \& Zanoli (2013)

A seguir, apresentamos duas sentenças como 'foco informativo', seguidas de suas imagens Praat (e antecedidas de suas respectivas sentenças-contexto):

\section{$\underline{\text { Sentença-Contexto }}$}

(14) Kal k'é kel bo família k'bo faló-m ma bo ka ta konxê? (FJL)

"Qual que é aquele parente que você me disse que não conhece?"

$\underline{\text { Foco Informacional }}$

(15)a. É un tia k’N ka ta konxê (MO- 9.I.2)

É un tia $k$ ' $\mathbf{N}$ ka ta konxê

COP DET tia FOC 1SG.NOM NEG HAB. conhecer

É uma tia que eu não conheço

b. (MO- 9.I.2)

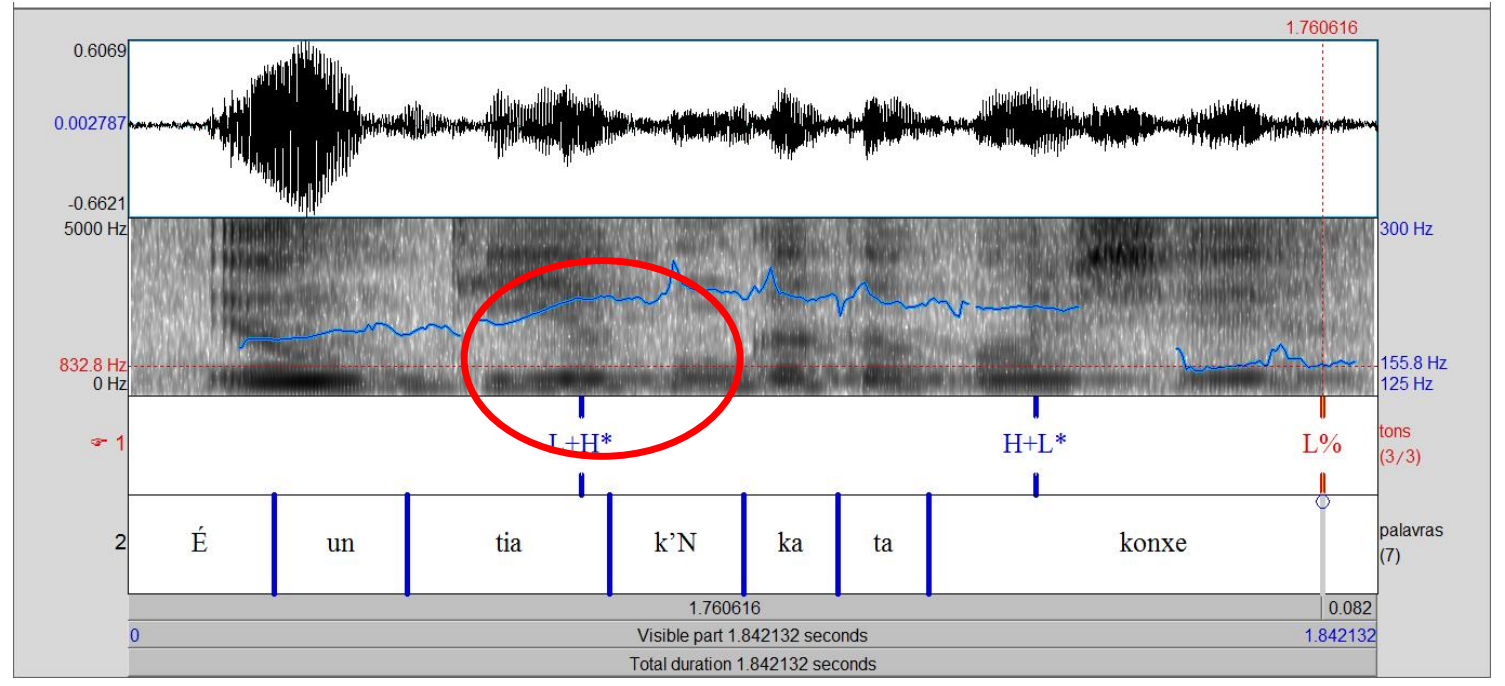

Figura 20: Imagem Praat- checagem de 'foco informacional' 


\section{$\underline{\text { Sentença-Contexto }}$}

(16) Kin k'ben d'Brazil aont? (FJL)

"Quem que veio do Brasil ontem?"

Foco Informacional

(17)a. É un moss k'ben d'Brazil aont (CA- 10.I.1)

$\begin{array}{llllllll}\mathbf{E} & \text { Un } & \text { moss } & \mathbf{k}^{\prime} & \text { ben } & \mathbf{d}^{\prime} & \text { Brazil } & \text { aont } \\ \text { COP } & \text { DET } & \text { moco } & \text { FOC } & \text { vir } & \text { Do } & \text { Brasil } & \text { ontem }\end{array}$

DET moço FOC vir Do

Foi um moço que veio do Brasil ontem

b. (CA- 10.I.1)

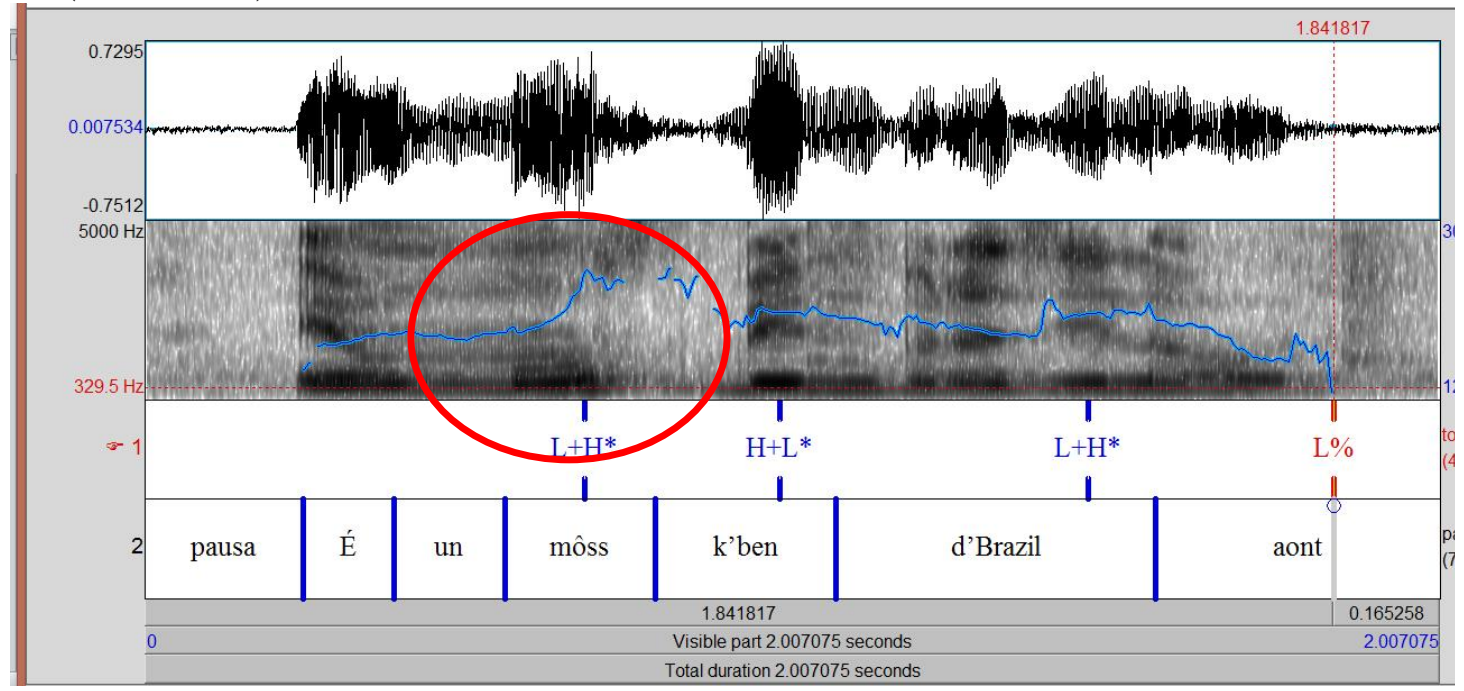

Figura 21: Imagem Praat- checagem de 'foco informacional'

Nas imagens (15b) e (17b) observamos uma ascendência da curva entoacional nos elementos un tia 'uma tia' (15b) e un moss 'um moço' (17b), ou seja, os elementos sujeitos focalizados das sentenças. Essa elevação é apontada pelo círculo em vermelho nas figuras.

No que refere à análise fonológica, as características gerais encontradas foram:

(i) predominância de bitonal crescente $\mathrm{L}+\mathrm{H}^{*}$, associado ao constituinte focalizado, como observamos no quadro abaixo:

\begin{tabular}{|l|l|}
\hline Tom & Número de ocorrências \\
\hline L+H* & 58 \\
\hline $\mathrm{H}^{*}$ & 1 \\
\hline $\mathrm{H}^{*}+\mathrm{L}$ & 1 \\
\hline
\end{tabular}

Quadro 19: Ocorrências tonais em sentenças com 'foco de informação' 
(ii) tom de fronteira L\% associado opcionalmente à fronteira direita da frase.

Como feito acima, apresentamos o quadro de Lopes \& Zanoli (2012) com as ocorrências de tipos de clivagens que marcam o 'foco informacional' do constituinte sujeito em São Nicolau. O quadro é apresentado antecedido por sua sentença-contexto: $\underline{\text { Sentença-Contexto }}$

(18) Kin k'ta papia d'más? (FJL)

Kin $\quad k$ ' ta papia d'más?

Quem COMP HAB falar demais

"Quem que fala demais?"

\begin{tabular}{|l|l|}
\hline a. Ôm & "homem" \\
\hline b. É ôm & "é homem" \\
\hline c. É ôm k'ta papia d'más & "é homem que fala demais" \\
\hline d.* Ôm k'ta papia d'más & "homem que fala demais" \\
\hline e. Ôm ta papia d'más & "homem fala demais" \\
\hline f. * Ta papia d'más ôm & "fala demais homem" \\
\hline g. Kin k'ta papia d'más é ôm & "quem que fala demais é homem" \\
\hline h. * Ôm é k'ta papia d'más & "homem é que fala demais" \\
\hline
\end{tabular}

Quadro 20: respostas possíveis ou não para o ‘foco informativo’ em São Nicolau

Fonte: Lopes \& Zanoli (2013)

Segundo o quadro 28, Lopes \& Zanoli (2012) assumem que a clivada canônica, como a que se exemplifica em (19c), é a estrutura default para o foco informativo da posição sujeito em São Nicolau.

Lopes \& Zanoli (2012) afirmam que, em São Nicolau, não é possível estruturas com dupla cópula para a marcação de 'foco de informação'.

Abaixo, apresentamos as ocorrências que encontramos em nossa análise: 


\begin{tabular}{|c|c|}
\hline Grupo & Ocorrências \\
\hline $\begin{array}{l}\text { (1) É uns mnininha k’robó-m goeba } \\
\text { É umas meninas que me roubaram goiaba }\end{array}$ & 6 \\
\hline $\begin{array}{l}\text { (2) É un munsinh k’panhó-b bo bol } \\
\text { É um rapaz que te apanhou o seu bolo }\end{array}$ & 6 \\
\hline $\begin{array}{l}\text { (3) É ôm k'ta papia d'más } \\
\text { É um homem que fala demais }\end{array}$ & 6 \\
\hline $\begin{array}{l}\text { (4) a.ốzé k' ta kmê midj } \\
\text { Asno é que come milho }\end{array}$ & 4 \\
\hline $\begin{array}{l}\text { b.É ôz k'ta kmê midj } \\
\text { É asno que come milho }\end{array}$ & 2 \\
\hline $\begin{array}{l}\text { (5) É } \mathbf{~ o ̂ m ~ k ' t a ~ p e g a ~ n a ~ n x a d a ~} \\
\text { É homem que pega na enxada }\end{array}$ & 6 \\
\hline $\begin{array}{l}\text { (6) a.É pai k’ta korriji fidj } \\
\text { É pai que corrige filho }\end{array}$ & 5 \\
\hline $\begin{array}{l}\text { b.É pai é k’ta korriji fidj } \\
\text { É pai é que corrige filho }\end{array}$ & 1 \\
\hline $\begin{array}{l}\text { (7) a.É kmida k’ta na txon } \\
\text { É comida que está no chão }\end{array}$ & 6 \\
\hline $\begin{array}{l}\text { (8) b.É gôt k'ta roba na panela } \\
\text { É gato que rouba na panela }\end{array}$ & 6 \\
\hline $\begin{array}{l}\text { (9) É un tia k’N ka ta konxê } \\
\text { É uma tia que eu não conheço }\end{array}$ & 6 \\
\hline $\begin{array}{l}\text { (10) a.É un moss k'ben d'Brazil aont } \\
\text { É um moço que chegou do Brasil ontem }\end{array}$ & 5 \\
\hline $\begin{array}{l}\text { b. Um moss é k'bem d'Brazil aont } \\
\text { Um moco que chegou do Brasil ontem }\end{array}$ & 1 \\
\hline
\end{tabular}

Quadro 21: Tipos de Clivagens em sentenças com 'foco informacional' - análise dessa pesquisa

Ao contrário da análise de Lopes \& Zanoli (2012), em nosso corpus, atestamos, ainda que com poucas ocorrências, estruturas com dupla cópula para a marcação do 'foco informacional' da posição sujeito, como se vê no grupo (6b) acima, repetida em:

(20) É pai é k’ta korriji fidj (MO- 6.I.2)

"É pai é que corrige filho"

Do mesmo modo, segundo Lopes \& Zanoli (2012), não são atestadas estruturas com clivagem invertida para a marcação de 'foco informacional' da posição 'sujeito' em São Nicolau. Entretanto, esse tipo de estrutura é atestada em nossa análise, como se vêem nas sentenças acima, no quadro, dos grupos (4) e (10b), renumeradas:

\section{(21) Ôz é k’ ta kmê midj}

"Asno é que come milho 


\section{(22) Um moss é k'bem d'Brazil aont}

"Um moço é que chegou do Brasil ontem"

Logo, com testes mais amplos, abrangendo um número maior de dados e de informantes, foi possível chegar a análises mais acuradas acerca do foco da posição de sujeito em São Nicolau.

Ao término desta seção e deste capítulo, é preciso ressaltar algumas questões. Uma delas diz respeito à tipologia. Importante que se diga, que, no que se refere à tipologia, não estendemos os estudos de modo a atestar tipos de foco como o "polar", atestado em línguas do substrato ${ }^{75}$. Desse modo, não podemos afirmar que tais tipo de foco não existam na língua estudada. Só podemos ratificar os tipos de foco contrastivo e o informacional.

A outra questão, ressaltada para fins de conclusão, é que a checagem do 'foco' da categoria 'sujeito' em cabo-verdiano, variedade de São Nicolau, se dá exclusivamente por estruturas clivadas e, preferencialmente, por:

- clivadas invertidas - para a marcação do foco contrastivo;

- clivadas canônicas - para a marcação do foco informacional.

Ao final, no âmbito da interface sintaxe-fonologia, ratificamos, por meio da análise da fonologia entoacional, que é possível diferenciar, prosodicamente, orações clivadas de orações relativas em São Nicolau. Mesmo que não tenhamos tratado de aspectos sintáticos neste trabalho, é sabido que, em construções como as apresentadas em (4) e (5), neste capítulo, analisadas como relativas, para tais sentenças, na literatura, tem sido proposta uma análise de clivagem sem cópula - ver entre outros Costa \& Duarte (2001: 628); Ribeiro (2009: 220). Nossa análise fonológica, ao ratificar que sentenças como (4) e (5) não contêm focalização, ratifica também que tais sentenças não podem ser clivadas. Logo, corroboramos estudos sintáticos como os de Mioto \& Negrão (2007: 173-177) que afirmam que "o sintagma complementizador das clivadas não contém uma relativa". Os autores (op cit.), ao afirmarem este fato, vão contra um enorme grupo na literatura que dizem o contrário: "clivadas contêm relativas" - ver, entre outros, Braga, Kato \& Mioto (2009: 283). Para maiores detalhes acerca da discussão envolvendo construções como as em (4) e (5) ditas clivadas sem cópula ver Oliveira (2004).

\footnotetext{
${ }^{75}$ Ver seção 3.1. do capítulo 3.
} 


\subsection{Síntese do capítulo}

Neste capítulo, corroboramos análises que enfocam o fato de que nem toda construção clivada contém uma relativa, ou seja, assumimos, com base nos resultados de nossa análise fonológica entoacional, que nem toda construção contendo um elemento ensanduichado entre a cópula e o morfema 'que' pode ser analisada como contendo relativa em CSN.

Para a análise apresentada, tomamos um grupo de sentenças relativas, diferenciando esse tipo de sentenças, das sentenças tidas como neutras, ratificando a análise de Âmbar (1992: 45), que entende por ordem menos marcada uma ordem não (ou menos) associada a alguma condição específica, seja de ordem sintática, prosódica, semântica ou pragmática. Logo, discordamos de Lopes (2012: 102) e Lopes \& Zanoli (2012) que consideram as sentenças relativas, embora sem marcação de foco, como sentenças neutras em suas análises para o cabo-verdiano de São Nicolau.

Contrapondo às sentenças relativas, analisamos ainda um grupo de sentenças com marcação de 'foco contrastivo' do constituinte 'sujeito' e outro com marcação de 'foco informacional', também do constituinte 'sujeito'.

No tocante às sentenças relativas, não atestamos predominância de nenhum bitonal específico. No entanto, diferentemente, nas sentenças focalizadas, nos dois tipos de foco (contrastivo e informacional), atesta-se o bitonal $\left(\mathrm{L}+\mathrm{H}^{*}\right)$, que predomina nos elementos focalizados 'sujeito'.

Ratificamos, ainda, nesse capítulo, o trabalho de Lopes \& Zanoli (2012) em que se atesta que em cabo-verdiano, variedade de São Nicolau, a categoria 'sujeito' só pode receber o traço 'foco' por meio de estrutura clivada. Logo, diferentemente do que apresentamos como característica do PE, que atesta sujeito posposto, em cabo-verdiano, tal como em PB, essa possibilidade não se confirma.

Chamamos a atenção ainda, para o elemento k’ de São Nicolau. Lopes (2012), ao descrever a natureza dos elementos introdutores de orações relativas, segue a proposta de De Vries (2002), que trata o elemento k', em sentenças relativas, como 'complementizador relativo. Diferentemente, Oliveira, Jorge \& Lopes (2013) demonstram uma ambiguidade teórica apontada em Lopes (2012) no tocante à nomenclatura/categorização utilizada, a partir de De Vries (2002), ao tratar o k’ em 
sentenças relativas. Para Oliveira, Jorge \& Lopes (2013), ou um elemento é complementizador ou é pronome/relativizador. Nessa dissertação, ratificamos, portanto, a proposta de Oliveira, Jorge \& Lopes (2013) de que o k' das relativas seja considerado pronome relativo $\left(\mathrm{PRO}_{\mathrm{REL}}\right)$ em CSN. Ratificamos, ainda, o fato de que, em sentenças focalizadas, o k' seja tratado como 'partícula marcadora de foco' ou [FOC].

Finalmente, com testes mais amplos, abrangendo um número maior de dados e de informantes, foi possível chegar a análises mais acuradas acerca da checagem 'foco' da posição de sujeito em São Nicolau. Apesar de corroborarmos a estrutura de clivagem como a única possibilidade de se realizar o 'foco' nesta variedade, atestamos diferentes tipos de clivagens na marcação do 'foco'.

Outros dois pontos a serem destacados, ao final, é que: (i) quanto à tipologia, não estendemos os estudos de modo a atestar tipos de foco como o "polar" - de línguas do oeste africano, desse modo, não poderemos afirmar que esses não existam na língua em questão. Em nossa análise atestamos apenas o foco contrastivo e o informacional, tipos esses atestados no português; (ii) ratificamos que estruturas clivadas em cabo-verdiano de São Nicolau não contêm relativa. 


\section{5- CONCLUSÃO}

Esta dissertação, que teve por objetivo a análise e a checagem de 'foco' da categoria 'sujeito' no cabo-verdiano de São Nicolau, foi construída em quatro capítulos centrais, além do introdutório e da conclusão.

No capítulo um, abordamos sobre o arquipélago de Cabo Verde, apontando acerca de sua formação histórica, desde a chegada dos portugueses nas ilhas, que eram tidas, pela maior parte dos estudiosos, como desabitadas. Entretanto, o arquipélago acabou se tornando um importante entreposto de escravos, devido sua localização privilegiada: estar na encruzilhada dos continentes americano, africano e europeu.

Com relação a São Nicolau, ressaltamos a importância histórica dessa ilha no arquipélago, pois lá se instaurou o primeiro Seminário-Liceu, que iniciou a institucionalização do ensino em Cabo Verde.

No segundo capítulo, iniciamos ratificando o fato histórico das Grandes Navegações portuguesas e do comércio escravocrata como o 'formador de línguas' e entre essas línguas o cabo-verdiano. Desse modo, apresentamos algumas hipóteses correntes na literatura sobre a gêneses das línguas crioulas, chamando a atenção do leitor para o fato de que, se tomarmos a gêneses do cabo-verdiano, como enfoque de análise, a única abordagem que não caberia a essa língua seria a 'gradualista'.

Ainda no capítulo dois, abordamos, no tocante à "crioulística/pidginística", o recente conceito de pidgincrioulo de Bakker (2003), baseado, principalmente, em parâmetros sociolinguísticos. Traçamos, sequencialmente, um panorama sociolinguístico de Cabo Verde, enfatizando a situação bilíngue/diglóssica do arquipélago, que convive com a língua materna - o cabo-verdiano - e a língua oficial o português. Apresentamos aspectos linguísticos do cabo-verdiano de São Nicolau a fim de corroborar a morfossintaxe nominal e verbal dessa língua; para essa variedade crioula ratificamos marcas de flexão, como por exemplo, o 'gênero', o 'número' no nome e ainda marca de flexão verbal.

No capítulo três, introduzimos o referencial teórico-metodológico utilizado na dissertação, enfatizando, no tocante à sintaxe, a tipologia de foco conforme apresentada em Zubizarreta (1997). Apresentaram-se, ainda, os resultados preliminares do trabalho realizado por Lopes \& Zanoli (2012) a respeito das estratégias de marcação de foco de informação e de foco contrastivo da categoria sujeito no cabo-verdiano, na variedade de 
São Nicolau, utilizando estudos já realizados em PB e PE como parâmetros de comparação. O trabalho aponta que, em São Nicolau, não é possível que o foco seja expresso por outra maneira senão por meio da clivagem. Logo, foi inserido, também, neste capítulo, um breve resumo acerca da operação “clivagem”. No tocante à fonologia entoacional, o referencial teórico utilizado para a análise, resenhamos a proposta de Ladd (1996), que afirma que a fonologia entoacional consiste em uma abordagem fonológica da estrutura entoacional da língua. Tal abordagem pressupõe que a entoação possui uma organização fonológica, conforme Pierrehumbert (1980); Beckman \& Pierrehumbert (1986); Pierrehumbert \& Beckman (1988); Hayes \& Lahiri (1991); entre outros.

Ainda no capítulo três, apresentamos o referencial metodológico, introduzindo o corpus utilizado na dissertação e explicitando como os dados foram coletados, organizados e analisados. Foi apresentado, também, o Programa Praat: a ferramenta utilizada para a análise entoacional das sentenças.

No capítulo quatro dedicamo-nos aos resultados da pesquisa. Partindo do alargamento do corpus, submetido à ferramenta Praat, ratificamos a análise realizada por Lopes \& Zanoli (2012): o foco da categoria ‘sujeito' nessa variedade de Barlavento só pode ser realizado por meio de estruturas clivadas. No entanto, nossa análise ampliou o escopo do estudo anterior, realizado pelos autores: (i) apontamos três tipos de clivadas que marcam a tipologia do 'foco' em São Nicolau; (ii) identificamos, por meio da fonologia entoacional, a predominância de um bitonal específico da categoria sujeito focalizada nessa variedade: $\mathrm{L}+\mathrm{H}^{*}$; (iii) por meio da análise da fonologia entoacional também apontamos a não predominância de um bitonal específico para as estruturas relativas.

Ressaltamos, em nosso estudo, que algumas estruturas aparentemente clivadas, não são de fato clivadas, pois apresentam estrutura relativa e, de acordo com alguns textos atuais da literatura, estruturas clivadas não contêm uma relativa. 


\section{REFERÊNCIAS BIBLIOGRÁFICAS}

Aboh, E. O. 2007. Information Structuring begins with the numeration. ACLC University of Amsterdam.

Alexandre, N. 2000. A Estratégia Resumptiva em Relativas Restritivas do Português Europeu, MA Diss., Lisboa: FLUL.

2006. Processos de relativização e marcadores relativos em Crioulo de Cabo Verde. In F. Oliveira \& J. Barbosa (eds.), Textos Seleccionados do XXI ENAPL 2005, LISBOA: COLIBRI, 83-95.

. 2009. Wh-Constructions in Cape Verdean Creole: Extensions of the Copy Theory of Movement. Dissertação de Doutoramento, Lisboa: Universidade de Lisboa.

Nélia A. \& Tjerk H. 2010. Os crioulos da Alta Guiné e do Golfo da Guiné: uma comparação sintáctica. Apresentação de trabalho no "7th Congress of African Studies, Lisbon”. Manuscrito.

2010. Uma análise de CP não expandido para o sistema de complementadores do Crioulo de Cabo Verde. In Textos Seleccionados do XXV ENAPL 2009, 111-126. Lisboa: Colibri.

. 2013. Crioulo de Cabo Verde: mecanismos de relativização e de interrogação. IV Seminário Internacional do Grupo de Estudos de Línguas em Contato (GELIC). São Paulo.

Jurgen, A. S. 2011. As estruturas reflexivas no português afro-brasileiro. Tese De Doutoramento, Salvador: Universidade Federal da Bahia.

Âmbar, M. M. 1992. Para uma sintaxe da inversão sujeito-verbo em Português. Lisboa: Edições Colibri.

. 1997. The Syntax of Focus in Portuguese - a unified approach. Lisboa: Universidade de Lisboa.

1999. Aspects of the Syntax of Focus in Portuguese. In Rebuschi, G. \& L. Tuller (eds.). The gramar of focus. Amsterdam/Philadelphia: John Benjamins Publishing Company.

Anderson, S. C. 1979. Verb structure. In Hyman, L. M. (ed.) Aghem grammatical structure. Occasional Papers in Linguistics No. 7. Los Angeles, University of Southern California.

Andrade, E. 1996. As Ilhas de Cabo Verde da descoberta à independência nacional (1469-1975). Paris: Edição L'Harmattan.

Areán-Garcia, N. 2009. Breve Histórico da Península Ibérica. Revista Philologus 15 (45). Rio de Janeiro: CiFEFiL, set./dez. 
Arends, J., P. Muysken \& Norval, S. (eds.). 1994. Pidgins and creoles an introduction. Amsterdam: John Benjamins.

Arends, J., S. Kouwenberg \& Norval S. 1994. Theories focusing on the non-European input. In: Jacques Arends, Pieter Muysken \& N. S. (eds.). Pidgins and creoles an introduction, 99-109. Part II, Theories of Genesis.

Arends, J. 1994. The socio-historical background of creoles. In: Arendes, J., Muysken, P. \& Norval, S. (eds.). Pidgins and creoles an introduction. Amsterdam: John Benjamins, pp. 15-25.

Arends, J. \& A. Bruyn. 1994. Gradualist and developmental hypotheses: In: Arends, J., Muysken, P. \& Norval, S. (eds.). Pidgins and creoles an introduction,111-120. Amsterdam: John Benjamins.

Argolo, W. 2013. Colonização e língua geral: o caso do sul da Bahia. Papia 23(1): 7596. São Paulo.

Bagno M. 2011. Gramática pedagógica do português brasileiro. São Paulo. Parábola Editorial.

Bakker, P. 1994. Pidgins. In Arends, J. Muysken, P. \& N. Smith (eds.). Pidgins and Creoles: an introduction, 25-39.

Bakker, P.; M. Post \& H. Voort. 1994. TMA Particles and Auxiliares. In: J. Arends; P. Muysken; N.Smith (eds.). Pidgins and Creoles: An Introduction. Philadelphia, USA: John Benjamins, 247-258

Bakker, P. 2003. Pidgin inflectional morphology and its implications for creole morphology. Kluwer Academic Publishers.

Bakker, P. \& P. Muysken. 1995. Mixed languages and language intertwining. In Arends, J., P. Muysken \& N. Smith. (eds.), 41-52.

Baptista, M. 2002. The sintax of Cape Verdean Creole - The Sotavento Varieties. John Benjamins Publishing Company. Amsterdan-Fhiladeelphia. Vol.54.

Barlavento e Sotavento. 2013. Termos náuticos. Disponível em

< http://pt.wikipedia.org/wiki/Barlavento_e_sotavento>. Acessado em 20 de novembro de 2013

Barbosa, P. 1995. Null Subjects. Dissertação de doutorado. Mass.: MIT.

. 2000. Clitics: a window into the null subject property. In Costa, J. (ed.). Portuguese Syntax. New comparative studies. Oxford University Press.

Barbosa, P., L. Duarte, \& M. A. Kato. 2001. A distribuição do sujeito nulo no português europeu e no português brasileiro. In C. N Correia \& A. Gonçalves. Actas do XVI Encontro Nacional da Associação Portuguesa de Lingüística, 539-550. Lisboa: Colibri Artes Gráficas 
Bechara. E. 2006. Moderna gramática portuguesa. 37ª Edição Revista e Ampliada. Rio de Janeiro: Lucena

Beckman, M.; J. Pierrehumbert. 1986. Intonational structure in Japanese and English. Phonology Yearbook 3.

Besten, Hans den; Pieter Muysken \&, Norval Smith.1994. Theories focusing on the European input. In: Arendes, J., Muysken, P. \& Norval, S. (eds.). Pidgins and creoles an introduction, 87-98. Amsterdam: John Benjamins.

Bickerton, D. 1984. The language bioprogram hypothesis. The brain and behavioral sciences 7(2):173-221.

.1988. Creole Languages and the Bioprogram. In: Newmeyer, F. (org.). Linguistics: The Cambridge survey, 268- 284. Vol 2. Cambridge: Cambridge University Press.

Boersma, P. \& D. Weenink. 2012. Praat: doing phonetics by computer. Disponível em: <http://www.fon.hum.uva.nl/praat/.> Acesso em: 20 de Janeiro de 2012.

Bonvini, E. 2008. Língua africanas e português falado no Brasil. In J. L. Fiorin, M. M. T. Petter (orgs). África no Brasil - a formação da língua portuguesa. São Paulo: Contexto.

Boxer, C. 2001. O império marítimo português (1415-1825). Ed. Revista, Lisboa, Edições 70.

Braga, M. L.; M. A. Kato, M \& C. Mioto. 2009. As construções-Q no português brasileiro falado. In M.A. Kato, M. da Nascimento (orgs). Gramática do português culto falado no Brasil - A construção da sentença, 241-289. Campinas: Editora da Unicamp.

Brásio, A. 1962. Descobrimento, povoamento, evangelização do arquipélago de Cabo Verde. In Revista Studia, 10.

Brito, A. 1967. Dialectos Crioulos - Portugueses. Apontamentos para a gramática do Crioulo que se fala na Ilha de Santiago de Cabo Verde. In Estudos LinguisticosCrioulos. Academia Internacional da Cultura Portuguesa.

Brito, A. M. 2007. Pidgins e crioulos - algumas questões. Guia IV para o Seminário apresentado na Universidade do Porto. Manuscrito.

Brito, A. M. \& I. Duarte. 2003. Orações relativas e construções aparentadas. In Mateus, Maria H. et al. Gramática da língua portuguesa, 653-694. Lisboa: Editorial Caminho,

Bloomfield, L. 1933. Language. Tübingen: Max Niemeyer Verlag.

Cabo Verde. 2014. Página Oficial do Governo da República de Cabo Verde. Disponível em <http://www.governo.cv/.> Acessado 12 de Agosto de 2014. 
Cabo Verde - 1914-18. 2013.Disponível em <www.momentohistorico,com/MH_02_907_marinha.ht>. Ultimo acesso em 29 de outubro de 2013.

Cabral. Pedro Álvares. 2013. Disponível em $<$ http://www.suapesquisa.com/pesquisa/cabral.htm>. Acessado em 26 de Novembro de 2013.

Calvet, L. J. 2002. Sociolinguística: Uma introdução crítica. (Trad. de Marcos Marcionilo). São Paulo: Parábola Editorial.

Câmara Jr., J. M. 1972. O nome e suas flexões. Estrutura da língua portuguesa, 77-88. Petrópolis: Vozes.

- 1974. Princípios de linguística geral: como introdução aos estudos superiores da língua portuguesa. Rio de Janeiro: Livraria Acadêmica.

1996. Considerações sobre o gênero em português, 115-129. Dispersos. Rio de Janeiro: Fundação Getúlio Vargas.

Cardoso, E. A. 1989. O crioulo da Ilha de S. Nicolau de Cabo Verde. Lisboa/ Praia. ICALP - ICL.

Carreira, A. 1982. Estudos de economia caboverdiana. Lisboa. Ed. Imprensa Nacional, Casa da Moeda.

Carreira, A. 1983. Migrações nas ilhas de Cabo Verde. Praia: Instituto Caboverdiano do Livro e do Disco.

Carvalho, Leandro. 2013. Disponível em <www.brasilescola.com/historiag/expansaomaritima-europeia.htm>. Ultimo acesso em 29 de outubro de 2013.

Chafe, W.1976. Givenness, contrastiveness, definiteness, subjectes and topics.In C. N. M Li (ed.). Subjects and topic. New York: Academic Press.

Cheng, L. 1991. On the Typology of Wh-Questions. Dissertação de Doutorado. Massachusetts Institute of Technology.

CIPPLOP - Comissão interpaíses Brasil - Portugal \& Países de língua oficial portuguesa. 2014. Disponível em < http://www.cipplop.org/site/paises/cabo.aspx>.

Coelho, A. 1881. Dialectos Romanicos ou Neo-Latinos na Africa, Asia e América. Lisboa: Imprensa Nacional.

Couto, C. F. 2001. Estratégias Familiares de Subsistência Rurais em Santiago de Cabo Verde. Tese de Mestrado. Instituto Superior de Ciências do Trabalho e da Empresa, Lisboa. 
Couto, H. H. \& F. Embaló. 2010. Literatura, Língua e Cultura na Guiné Bissau, no país da CPLP. PAPIA 20. Brasília: Universidade de Brasília/Thesaurus.

Coutinho, I. L. 1976. Pontos de Gramática Histórica. 7 ed. Rio de Janeiro: Ao Livro Técnico Indústria e Comércio.

Cook, T. 2002. Focus in Efik. Journal of African Languages and Linguistics: 23-2.

Cortesão, J. 1962. História dos descobrimentos portugueses. Lisboa: Edições Arcádia.

Costa, J. 1996. Word Order and Constraint Interaction. Seminários de Lingüística, 65102. Universidade do Algarve.

.1998. Word Order Variation. Aconstaint-based aproach. Netherlands: Holland Academic Graphics.

2004. Subject positions and interfaces: the case of European Portuguese.

Berlin/New York: Mouton de Gruyter.

Costa e Silva, A. 2012. Imagens da África. Penguim \& Cia das Letras, SP.

Costa, J. \& I. Duarte (2001). Minimizando a estrutura: uma análise unificada das construções de clivagem em português. In Actas do XVI encontro nacional da associação portuguesa de lingüística, 627 - 738. Lisboa.

Couto, H. H. 1998. Um cenário para a crioulização sem pidginização. Revista de Estudos Linguísticos, v.7 (1): 5-30.

Creissels, D. \& S. Robert. 1998. Morphologie verbale et organisation discursive de l'énoncé: l'exemple du Tswana et du Wolof. Faits de langues (11-12).

Decreto-Lei n ${ }^{\circ}$ 67/1998. "Bases do Alfabeto Unificado para a Escrita do Crioulo caboverdiano”, Boletim Oficial - 5 Suplemento, 48, 31 de Dezembro, 19-23.

DeGraff, M. 2001. Morphology in creole genesis: Linguistics and Ideology. In Michael Kenstowicz (ed). Ken Hale: a life in language, 53-122. Cambridge, Massachusetts: the MIT Press.

Delgado, C. A. 2009. Crioulos de Base Lexical Portuguesa como factores de identidades em África: o caso de Cabo Verde (subsidios para uma abordagem metodológica). Instituto da Biblioteca Nacional e do Livro. Praia.

Duarte, D. 1977. A problemática da utilização das línguas nacionais: língua, nação, identidade, cultura. Raízes 5/6 (2): 35-80.

Duarte, D. A. 1998. Bilinguismo ou Diglossia? Spleen edições, Praia.

Estatísticas. Disponível em < http://www.ine.cv>. Acessado em 25 de Novembrode 2013. 
Ferguson, C. A. 1959. Diglossia. Word 15: 325-334.

Fernandes, F. R. 2007. Ordem, focalização e preenchimento em português: sintaxe e prosódia. Tese de Doutorado. Universidade Estadual de Campinas.

Fernandes-Svartman, F. R. 2012. A entoação das sentenças clivadas em português brasileiro e a interface sintaxe-fonologia. Filologia e Linguística Portuguesa 14(1): 3756.

Fiorin, J. L. \& M. M. T. Petter. 2008. África no Brasil - a formação da língua portuguesa. São Paulo: Contexto.

Fotolog: imagens de Cabo Verde. 2002. Disponível em <http://www.fotolog.com/praia_bote/43949997/>. Acessado em 14 de Julho de 2014.

Fricke-Matte, A. C. 2006. O que a fonética tem a ver com software livre? Disponível em: <http://under- linux.org/wiki/index.php/Artigos/fonetica-software livre. Out/2006.> Acesso em: setembro de 2013.

Softwares e imóveis. Disponível em: <http://under-linux.org/b103-software-eimoveis Abr/2008>. Acesso em outubro de 2013.

Frota \& M. Vigário. 2000. Aspectos de prosódia comparada: ritmo e entoação no PE e no PB. In: CASTRO, R. V.; BARBOSA, P. (eds.). Actas do XV Encontro Nacional da Associação Portuguesa de Linguística. Coimbra: APL.

Galves, C.1998. Tópicos, sujeitos, pronomes e concordância no português brasileiro. In Cadernos de Estudos Linguísticos, $\mathrm{n}^{\circ} 34$. Campinas: Editora da Unicamp.

Givón, T. 1975. Focus and the scope of assertion: some Bantu evidence. Studies in African Linguistics: 6 (2).

Góis, P. 2006. Emigração cabo-verdiana para [e na] Europa e a sua inserção nos mercados de trabalho locais, 44. Lisboa: ACIDI.

Gómez, E. G. 2012. Orígen de Pidgin. Disponível em <http://www.etnografo.com/origen_de_pidgin.htm>. Acessado em 15 de Julho de 2014.

Gomes, F. A. 2014. Mapa do arquipélago de Cabo Verde. Disponível em:

<http://patchparloa.blogspot.com.br/2011/01/nha-terra-cap-verde.html>. Acessado em 09 de Julho de 2014.

Gomes, L. 2010. António de Noli, o descobridor oficial e primeiro povoador das ilhas de Cabo Verde. Jornada Internacional de estudos sobre António di Noli - descobridor de Cabo Verde, por acasião do $550^{\circ}$ aniversário.

Hayes, B. \& A. Lahiri, 1991. Bengali intonational phonology. Natural Language \& Linguistic Theory 9 (1): 47-96. 
Holm, J. 1980. The creole 'copula' that highlighted the world. In J. Dillard (org.). Perspectives on American English, J. L. Dillard (org.). New York: Mouton Publishers.

1988. Pidgins and creoles. Volume 1: Theory and structure. Cambridge: Cambridge University Press

2004. Languages in contact - the partial restructuring of vernaculars.Cambridge: Cambridge, MA.: Cambridge University Press.

Holm, J. \& L. Inverno. 2005. The vernacular Portuguese of Angola and Brazil: partial restructuring of the noun phrase. Comunicação apresentada no Encontro Anual da Associação: Crioulos de Base Lexical Portuguesa e Espanhola, Université d'Orléans.

Holm, J. 2013. Sixteenth-century evidence regarding the origins of the Capeverdean verbal marker -ba Evidências seiscentistas sobre a origem do marcador verbal -ba do kabuverdianu. Papia, São Paulo, 23(1): 39-49.

Hyman, L. M. 1979. Aghem grammatical structure. Los Angeles, University of Southern California. Southern California Occasional Papers in Linguistics No. 7.

Hyman, L. M. \& J. R Watters. 1984. Auxiliare focus. Studies in African Linguistics 15(3).

Ilha de São Nicolau. In: Wikipédia, a enciclopédia livre. Flórida: Wikimedia Foundation, 2013. Disponível em: <http://pt.wikipedia.org/w/index.php?title=Ilha_de_S\%C3\%A3o_Nicolau\&oldid=3446 4242>. Acesso em: 14 jul. 2014.

Instituto Nacional de Estatística. INE. 2013. Disponível em http://www.ine.pt/xportal/xmain?xpid=INE\&xpgid=ine_main.

Jacobs, B. 2010. Upper Guinea Creole: Evidence in Favor of a Santiago Birth. Journal of Pidgin and Creole Languages 25:2. John Benjamins Publishing Companay.

Kato, M. A. 1993. The distribution of null and pronominal objects in Brasilian Portuguese. Linguistic Perspectives on the Romance Languages: selected papers from the XXI Linguistic Symposium on Romance Language, ed. By: W. Ashby; M. Mithum; G. Perissinoto \& e. Raposo. Amsterdam \& Philadelfhia: John Benjamins.

Kato, M.A. et all. 1996. Padrões de predicação no português falado no Brasil. In: Kato, M.A (org) Gramática do português falad. Vol. V:Convergências. Campinas, SP: Editora da Unicamp.

Kato,M.A.1989. Sujeito e tópico: duas categorias em sintaxe? Cadernos de estudos

Kato, M. A \& E. Raposo. 1996. European and Brasilian Portuguese word order: questions, focus and topic constructions. In: C. Quicoli, M. Saltarelli \& M. L. Zubizarreta. (eds). Aspects of romance linguistics. Selected papers from the LSRL XXVI. Washigton: Georgetown University Press. 
Kato, M. A. 1999. Strong and weak pronominals in the null subject parameter. Probus, 11: 1-37.

Kato, M. A. 2000. The partial pro-drop nature and the restricted VS order in Brazilian Portuguese. In: M. Kato \& E. Negrão (eds.). Brasilian Portuguese and the null subject parameter. Madrid: Iberoamericana.

Kato, M. A \& C. Mioto. 2005. A multi- evidence stdy of European and Brasilian Portuguese wh-questions. In Stephen Kepser; Marga reis. Linguistic Eividence: Empirical, theorical and computacional perspectives. Mouton: [s.n].

Kato, M. \& I. Ribeiro. 2005. Cleft sentences and wh-questions in Brazilian Portuguese: a diachronic analysis. Comunicação apresentada no 35th LSRL. University of Texas, Austin.

Kenedy, E. 2008. Gerativismo. In Mário Eduardo Toscano Martelotta. (org.). In.: Manual de lingüística. São Paulo: Contexto, 1: 127-140.

Kiss, K.1998. Identificacional focus versus information focus. Language: 74.

Kihm, A. 1994. Kriyol syntax: the Portuguese-based Creole language of GuineaBissau. Amsterdam, the Netherlands: John Benjamins.

Kuno, S. 1972. Functional sentence perspective: acase study from Japanese and English. Linguistic Inquiry: 3.

Ladd, D. R. 1980. The Structure of Intonational Meaning: evidence from English. Bloomington, Indiana: Indiana University Press.

. 1983. Peak features and overall slope. In D. R. Ladd. \& A. Cutler (eds.). Prosody: Models and Measurements. Berlim: Springer Verlag, p. 39-52.

. 1990. Intonation: emotion vs. grammar. (Review of Bolinger 1989). Language, 66: 806-816. 1996. Intonational Phonology. Cambridge: CUP.

Lemos M. 2010. Influências e domínio de uma língua sobre outra(s).

Matraga, Rio de Janeiro, 17(26), jan./jun.

Leusen, N. V. \& L. Kálmán. 1993. The interpretation of free focus. Universidade de Amsterdã, ms.

Lightbown, P.M. \& L. White. 1987. The influence of linguistic theories on language acquisition research: description and explanation. Language Learning 37, 483-510.

Lopes, A. V. C. M. 2011. As línguas de Cabo Verde: uma radiografia sociolinguística. Dissertação de doutorado. Universidade de Lisboa. 
Lopes, M. 1989. "A exploração económica da Guiné e de Cabo Verde nos séculos XV e XVI", in: Luís de Albuquerque (org.). Portugal no Mundo, (I) 250-263.Lisboa, Publicações Alfa.

Lopes da Silva, B. 1984. O dialecto crioulo de Cabo Verde. Cabo Verde: Imprensa Nacional.

Lopes, F. J. 2010. Paralelismos entre os processos de formação, gramatização e nacionalização da língua portuguesa e os da língua caboverdiana. In $7^{\circ}$ Congresso Ibérico de Estudos Africanos, 9, Lisboa, 2010 - 50 anos das independências africanas: desafios para a modernidade: Actas [Online]. Lisboa: CEA, 2010. [Consultado em 18 de outubro de 2011]. Disponível em: http://hdl.handle.net/10071/2352.

2011. O bilinguismo e a problemática da diglossia no processo de letramento: o caso de Cabo Verde e suas diásporas. PAPIA 21 (1), 123-136.

2012. Para Uma Análise Sintática das Construções Relativas no Crioulo da Ilha de São Nicolau - Cabo Verde. Dissertação de Mestrado. Universidade de São Paulo. SP.

Lopes, F. J. \& M. L. Zanoli. 2012. Considerações sobre foco na posição de sujeito no crioulo de São Nicolau. Trabalho apresentado no Congresso em conjunto da $13^{\circ}$ ACBLPE $/ 7^{\circ}$ ABECS. Universidade de São Paulo. Manuscrito.

2013. Corpus de pesquisa de Mestrado para Experimento de Obtenção de Foco no Crioulo de São Nicolau. Universidade de São Paulo. Manuscrito.

Lopes, F. J. (a sair) O português falado em cabo-verde: o estado da arte. In Antunes, G. Antunes, P. J. Pilar \& M. S. D. Oliveira (orgs). Português na África Atlântica. SP: Parábola (?).

Lucchesi, D. \& A. Baxter. 2006. Processos de crioulização na história sociolinguística do Brasil. In Cardoso, S.; J. Mota; R. V. M. S. (Org.). Quinhentos Anos de História Linguística do Brasil, 163-218. Salvador: Secretaria da Cultura e Turismo do Estado da Bahia.

2009. A transmissão linguística irregular. In Lucchesi, D. \& I. Ribeiro (Orgs.). O português Afro-Brasileiro. 101-124. Salvador: Edufba.

Martins, A. B. 2009. Relações entre Portugal e Cabo Verde antes e depois da independência. Tese de Mestrado. Universidade Lusófona de Humanidades e Tecnologias.

Matras, Y. \& P. Bakker (eds.). 2003. The mixed language debate: theoretical and empirical advances. Berlin, New York: Mouton de Gruyter. (Trends in Linguistics. Studies and Monographs 145)

Mioto, C. 2003. Focalização e quantificação. Revista Letras. Curitiba: Editora UFPR, 61. 
Mioto, C \& E. V. Negrão. 2007. As sentenças clivadas não contêm relativas. In: A. T. Castilho et al. (Org). Descrição, história e aquisição do português brasileiro, 159-184. Campinas: Pontes; São Paulo: FAPESP.

McWorther, J. 1992. Substratal influence in Saramaccan serial verb construction. JPCL 7, 1-53.

Modesto, M. 2001. As construções clivadas no português do Brasil: relações entre interpretação focal, movimento sintático e prosódia. São Paulo: Humanitas.

Monteiro, J. L. 2010. Influências e domínios de uma língua sobre outra(s).UNIFOR, UFC. Matraga, Rio de Janeiro, 17 (26).

Monteiro Fernandes A. C. 2007. Guiné-Bissau e Cabo Verde: da unidade à separação. Tese de Mestrado. Universidade do Porto. Porto.

Mufwene, S. 1986. The Universalist and Substrate Hypotheses Complement One Another. In Muysken, P. \& N. Smith (eds.). 1986. Substrata Versus Universals in Creole Genesis - Papers from the Amsterdam Creole Workshop, 129-163. Amsterdam/Philadelphia: John Benjamins.

Mühlhäusler, P. 1986. Pidgin \& Creole Linguistics. Londres: Basil Blackwell.

Muysken, P. \& N. Smith. 1994. The study of pidgin and creole languages. In Arends J., P. Muysken \& N. Smith (eds.). Pidgins and Creoles: an introduction, 3-14. Amsterdam: John Benjamins.

Muysken, P. \& T. Veenstra 1994. In Pidgins and Creoles: An introduction, 121134. Arends, J., P. Muysken \& N. Smith (eds.).

Negrão, E. V. 1992. Tem uma história que eu quero contar que começa assim: peculiaridades de uma sentença existencial. Cadernos de Estudos Linguísticos (22): 8190 .

Neves, B. S. 2008. O Seminário - Liceu de S. Nicolau - contributo para a história do ensino em Cabo Verde. Porto. CEAUP.

Oliveira, M.S.D. 2005. Perguntas de constituinte em Ibibio e a teoria de tipo oracional: aspectos da periferia à esquerda com ênfase em foco. Muenchen: LINCOM Studies in african Linguistics, 65 .

2006. Aspectos da Periferia esquerda da Sentença e da sintaxe pronominal: tópicos de investigação da Participação das Línguas Africanas na constituição do português do Brasil. Extensão de projeto de pesquisa aprovado pela Comissão Especial de Regimes de trabalho da Universidade de São Paulo, manuscrito.

. 2007. Remarks in tense markers grammatically and pragmatically controlled.Paper presented at LLACAN (Langage, Langues et Cultures d'Afrique Noire), Centre National d la Recherche Scientifique.Paris: CAPES/COFECUB Project.Manuscript. 
Oliveira, M.S.D \& S. A. S. Souza. 2009. Perguntas de constituinte (WH) em Caboverdiano: Evidências de foco obrigatório. In Papia 19.

Oliveira, M. S. D. 2010. Análise Sintática do Português Falado no Brasil. Rio de Janeiro: Editora Multifoco.

Oliveira, M.S.D. de. \& J. Holm. 2011. Estruturas-QU fronteadas e o 'foco gramaticalmente controlado' - a participação de línguas africanas em línguas parcialmente e completamente reestruturadas. Papia, 21(1), 23-38.

Oliveira, M. S. D. 2011. Focus in Brasilian Portuguese, 121-134. In Petter \& Vanhove (orgs). Portugais et langues africaines études afro-brésilienes.

Oliveira, M. S. D.; L. T. Jorge \& F. J. Lopes. 2013. Estruturas relativas do português em Cabo Verde: revisitando complementizadores e relativos. Trabalho apresentado no IV Simpósio Mundial de Língua Portuguesa - SIMELP. Simpósio 12 - Variedades de português faladas na África: os substratos línguas 'Níger Congo' e 'Crioulas'.

Oliveira. M. S. D. 2014. DPs/WHs followed by highlighter in Atlantic restructured languages: a non cleft construction, 401-421. In Papia 24(2).

Paixão de Souza, M. C. 2006. Lingüística histórica, 11- 48. In Pfeiffer, C.; H. Nunes. (Orgs.). Introdução às Ciências das Linguagens: Língua, Sociedade e Conhecimento. 1 ed. Campinas: Pontes, v. 3.

2012. Apontamentos sobre a formação da Língua Portuguesa. Linguística Histórica do Português: Aula 1. Curso de Pós-Graduação. DLCV/ FFLCH/ USP, Manuscrito.

2012. Algumas Questões Trazidas pelas Grandes Genealogias (o "Contato"). Linguística Histórica do Português: Aulas 7 e 8. Curso de Pós-Graduação. DLCV/ FFLCH/ USP. Manuscrito.

Pereira, E. A. C. 2006. Os caminhos da revolta em Caboverde e a cultua da resistência: As revoltas dos Engenho (1822) e de Achada Falcão (1841). Dissertação de mestrado USP. SP.

Pereira, D. A. 2011. Das relações históricas Cabo verde - Brasil. Brasilia: Fundação Antonio Gusmão.

Petter, M. M. T. \& B. Caron. (orgs.). 2005. Projeto: a participação das línguas africanas na constituição do português brasileiro.

Pierrehumbert, J. 1980. Thephonology and phonetics of English intonation. Dissertação de Doutorado. Mass.: M.I.T.

Press.

\& M. Beckman. 1988. Japanese Tone Structure. Cambridge, Mass.: M. I. T. 
Pinto, A. R. et al. 2011. Manual de normalização de trabalhos acadêmicos. Viçosa, MG. Disponível em:<http://www.bbt.ufv.br/>. Acesso em: 22 de março de 2014.

Poli, T.C. 2008. A periferia à esquerda da sentença no português brasileiro: funções discursivas de seus constituintes e sua derivação. Tese de doutorado. USP.

Quadro europeu comum de referência para línguas. In: WIKIPÉDIA, a enciclopédia livre. Flórida: Wikimedia Foundation, 2014. Disponível em: <http://pt.wikipedia.org/w/index.php?title=Quadro_Europeu_Comum_de_Refer\%C3\% AAncia_para_L\%C3\%ADnguas\&oldid=39221382>. Acesso em: 25 jul. 2014.

Quinquin. 2007. disponível em <img src="http://visit.webhosting.yahoo.com/visit.gif?us1374088073"src="http://visit.webho sting.yahoo.com/visit.gif?us1374088073" alt="setstats" border="0" width="1" height="1">. Ultimo acesso em 29/10/2013.

Quint, N. 2000. Grammaire de la langue cap verdiene. L'Harmattion. Paris - France.

2008. O preenchimento da posição de sujeito em português do Brasil: Deriva versus Crioulização. In J. L. Fiorin \& M. M. T. Petter (orgs) África no Brasil - a formação da língua portuguesa. São Paulo: Contexto.

Ribeiro, I. \& M. A. Kato. 2007. A posição do foco predicativo no período v2 e no português moderno. (apresentação de trabalho/seminário)

Ribeiro, L. \& M. Côrtes Júnior. 2009. As construções pseudoclivadas e clivadas. In Lucchesi, D., A. Baxter \& I. Ribeiro (orgs). O português afro-brasileiro, 209-230. Salvador: EDUFBA.

Rodrigues, A. 1996. As línguas gerais sul-americanas. Laboratório de línguas indígenas, Brasilia. Disponível em: 〈http://www.unb.br〉. Acesso em 10 junho 2014.

Romaine, S. 1994. Language in Society - An Introduction to Socio-linguistics. Oxford: Oxford University Press. Oxford

Rooij, V. 1994. Variation, 53-64. In J. Arends, Jacques; P. Muysken \& N. Smith. Pidgins and Creoles: An Introduction. Amsterdam; Philadelphia: John Benjamins.

Rosa, M. C. 2000. Introdução à Morfologia. São Paulo: Contexto.

Santos, E. F. 2010. A periferia esquerda da sentença no português de Angola. Dissertação de mestrado. Universidade de São Paulo. SP.

Santos, E. F. \& M. S. D. Oliveira. 2011. Aspectos da Categoria Foco no Português de Angola. Filologia e Linguística Portuguesa. São Paulo: n. 13(2), p. 269-303.

São Nicolau. Disponível em <http://www.suapesquisa.com/pesquisa/htm>. Acessado em 28 de Maio de 2014. 
Schuchardt, H.1882. Kreolische Studien.

Scott, A. S. 2010. Os portugueses. Ed. Contexto. SP.

Segerer, G. 2000. La focalisation en Bijogo. In: B. Caron (ed.) Topicalisation et focalisation dans les langues africaines. Louvain- Paris: PEETERS, Collection Afrique et Langage: 1.

Silva, A. D. 1929. A instrução pública em Cabo Verde. In Boletim da Agência Geral das Colónias. Lisboa, Ano 5 (45).

Silva, T. V. 1998. Kiriolu: Sped- ju di nos Alma. Cultura, 2: 108-121.

Souza, J. A. 2011. As estruturas reflexivas no português afro-brasileiro. Universidade Federal da Bahia. Salvador.

Tavares, E. 1969. Mornas - cantigas crioulas. Luanda: Liga dos Amigos de Cabo Verde.

Tavares Silva, C. R. 2004. A Natureza de AGR e suas implicações na ordem VS: um estudo comparativo entre o português brasileiro e o português europeu. Tese de Doutorado. Alagoas: Universidade Federal de Alagoas.

Tenani, L. E. 2002. Domínios prosódicos no Português do Brasil: implicações para a prosódia e para a aplicação de processos fonológicos. Campinas. Tese de Doutorado. Universidade Estadual de Campinas.

TVC. Disponível em <http://www.rtc.cv/tcv/index.php>. Acessado em 06/02/2014.

Thomason, S. G. \& T. Kaufman. 1986. Language contact, creolization, and genetic linguistics. Berkeley: University of California Press.

Thomason, S. G. 2001. Language contact: an introduction, 21-39. In Matras and Bakker (eds.). Social factors and linguistic processes in the emergence of stable mixed languages. Edinburgh: Edinburgh University Press.

1997. Contact languages. Amsterdam: John Benjamins.

Tuller, L. 1992. The syntax of postverbal focus constructions in Chadic. Natural Languages and Linguistic Theory: 10.

Uriagereka, J. 1988. On government. PhD diss., University of Connecticut.

Veiga, M. 1982. Diskrison Strutural di Lingua Kabuverdianu. Praia: Instituto Nacional do Livro e do Disco. 
1996. O Crioulo de Cabo Verde- Introdução à gramática do Crioulo. Praia: Instituto da Biblioteca Nacional do Livro.

2002. O Caboverdiano em 45 lições. Portugal / Cabo Verde. INIC.

do Livro.

2004. A Construção do Bilinguismo. Praia: Instituto da Biblioteca Nacional

(2009) O crioulo e o português em Cabo Verde. In: Sibila: Poesia e crítica literária. Disponível em: http://sibila.com.br/mapa-dalingua/o-criouloe-o-portugues-emcabo-verde/2753. Acessado em 26 de maio de 2014.

Vigário, M. 1998. Aspectos da Prosódia do Português Europeu: estruturas com advérbio de exclusão e negação frásica. Braga: CEHUM.

. 2003. The Prosodic Word in European Portuguese. Berlin-New York: Mouton de Gruyter.

Vries, Mark de. 2002. The Syntax of Relativization. LOT Publications: PhD Dissertation, University of Amsterdam

Watters, J. 1979. Focus in Aghem. In: Hyman, L. (ed.). Aghem grammatical structures, p. 137-97. Los Angeles: University of Southern California, Southern California Occasional Papers in Linguistics No. 7.

Zubizarreta, M.L. 1997. Prosody, focus and order. University of Southern Califórnia, Departamento of Linguistics, Los Angeles, CA, Manuscript.

1998. Prosody, Focus, and Word Order. Cambridge, Massachusetts/ London.The MIT Press. 


\section{APÊNDICE}

\section{Lopes \& Zanoli (2012)}

LOPES, Francisco João; ZANOLI, Maria de Lourdes. 2013. Corpus de pesquisa de Mestrado para Experimento de Obtenção de Foco no Crioulo de São Nicolau. Universidade de São Paulo. Manuscrito.

O presente corpus constitui-se de gravações com falantes nativos do crioulo de Cabo Verde, na variedade da ilha de São Nicolau - região de Barlavento. A base para a construção do corpus foi um questionário controlado, elaborado e organizado por Francisco João Lopes em parceria com Maria de Lurdes Zanoli, a fim de obtermos construções com ocorrências de foco. Para tal, construímos situações contextos a fim de obter as requeridas construções. Todas as sentenças contextos fora elaboradas por Francisco João Lopes - falante nativo de cabo-verdiano de São Nicolau.

O corpus foi utilizado em três momentos: (i) Lopes (2012) - dissertação de mestrado; (ii) Lopes \& Zanoli (2012) - ACPLPE-ABECS; (iii) Zanoli (2013)dissertação de mestrado. Desse modo foram coletados 10 grupos de sentenças contendo construções relativas e clivadas na variedade de São Nicolau, para checar as estratégias para a realização de foco no constituinte sujeito.

\section{GRUPO 1}

Sentença contexto:

Kin k' torna bem oj?

Quem COMP voltar vir hoje?

Quem voltou hoje?

1.1. Sentença relativa

Uns mnininha k'robó-m goeba torna ben oj

Uns minininha $\mathbf{k}^{\prime}$ robó $\mathbf{m}$ goeba torna ben oj DET Meninas PRO $_{\text {rel }}$ roubar 1.SG.OBJ Goiaba Voltar vir hoje As meninas que me roubaram goiaba voltaram hoje.

\subsection{Sentença com foco contrastivo no constituinte sujeito}

Sentença contexto:

Ont bo faló-m ma uns munsinh robó-b goeba, é dvera, ka é? 
“Ontém você me falou que uns meninos me roubaram goiaba, é verdade, não é?"

(Naun) É uns mnininha k'robó-m goeba

(Naun) $\quad$ É uns mnininha $k$ ' robô- m boeba

(Naun) COP DET MENINAS FOC roubar 1.sg. DAT goiaba

(Não) Foram as meninas que roubaram minha goiaba

1.3. Sentença com foco informativo no constituinte sujeito

Sentença contexto:

Kin k'robó-b goeba?

"Quem que roubou-me goiaba?"

É uns mnininha k'robó-m goeba

$\begin{array}{llllll}\mathbf{E} & \text { Uns } & \text { Minininha } & \mathbf{k}^{\prime} & \text { Robó } & \mathbf{M}\end{array}$

COP DET Meninas FOC Roubar 1.SG.DAT Goiaba

Foram as meninas que me roubaram goiaba.

\section{GRUPO 2}

2.1. Sentença relativa

Un musinh k'panhó-b bo bol sei ta korê

Un Munsinh $k^{\prime} \quad$ Robó $-b \quad$ goeba sei ta korê

DET Menino PRO $_{\text {rel }}$ Roubar 2SG.DAT goiaba sair TAM correr

O menino que te roubou goiaba saiu correndo.

2.2. Sentença com foco contrastivo no constituinte sujeito

Sentença contexto:

Kand k'N dja bo faló-m ma un mnininha panhô-m nha bol

"Quando eu cheguei você me falou que uma menina roubou o meu bolo."

Naun, un munsinh é k'panhó-b bo bol.

Naun, un Munsinh É $\quad k^{\prime} \quad$ Panhó b bo bol

NEG DET Menino COP FOC Roubar 2SG.DAT bolo.

Não, um menino é que te roubou goiaba.

2.3. Sentença com foco informativo no constituinte sujeito

Sentença contexto:

k'panhó-m nha bol? 
"Quem roubou meu bolo"

É un munsinh k’panhó-b bo bol.

É un Munsinh $\mathbf{k}^{\prime}$ Panhó $B$ goeba

COP DET Menino FOC roubar 2SG.OBJ goiaba

Foi um menino que te roubou goiaba.

\section{GRUPO 3}

Sentença contexto:

Kin k' ka é d'fiança?

Kin k' ka é d'fiança?

Quem COMP NEG COP de confiança

Quem que não é de confiança?

\subsection{Sentença relativa}

Ôm k'ta papia d'más ka é d'fiansa

$\begin{array}{lllllllll}\hat{\text { Omm }} & \mathbf{k}^{\prime} & \text { Ta } & \text { Papia } & \text { d'más } & \text { Ka } & \text { é } & \text { d' }^{\prime} & \text { fiansa } \\ \text { Homem } & \text { PRO }_{\text {rel }} & \text { HAB } & \text { Falar } & \text { Demais } & \text { NEG } & \text { COP } & \text { De } & \text { confiança }\end{array}$

Homem que fala demais não é de confiança.

\subsection{Sentença com foco contrastivo no constituinte sujeito}

Sentença contexto:

Anton na Saninklau ta falód ma jent mdjer ta papia d'más, é dvera?

"Então, em São Nicolau se diz que as mulheres falam demais, não é verdade?"

Mtira, ôm é k'ta papia d'más

Naun ôm $\quad E^{\prime} \quad k^{\prime} \quad$ ta $\quad$ papia d'más

Naun homem COP FOC HAB falar Demais

Não, homem é que fala demais.

3.2. Sentença com foco informativo no constituinte sujeito

$\underline{\text { Sentença contexto: }}$ 
Kin k'ta papia d'más?

"Quem que fala demais?"

É ôm k'ta papia d'más

$\begin{array}{llllll}\mathbf{E} & \mathbf{o m} & k^{\prime} & \text { Ta } & \text { Papia d'más }\end{array}$

COP homem FOC HAB Falar demais

É homem que fala demais.

\section{GRUPO 4}

4.1. Sentença relativa

Ôz k'ta kmê midj ten forsa

$\hat{O} z$ ta $k^{\prime}$ ta $k m e ̂$ midj ten forsa

asno $\quad$ PRON $_{\text {rel }} \mathrm{HAB}$ comer milho ter força

$O$ asno que come milho tem força.

\subsection{Sentença com foco contrastivo no constituinte sujeito}

Sentença contexto:

Nton, na Saninklau galinha é k'ta kmê midj?

"Então, em São Nicolau as galinhas é quem comem milho?"

Bo sta nganód, ôz é k’ta kmê midj

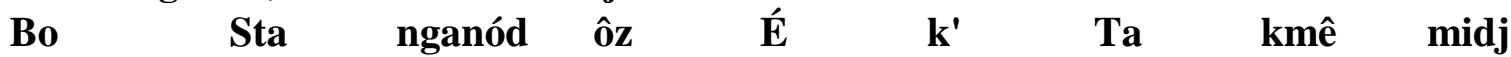

2SG.NOM estar enganado asno COP FOC HAB comer milho

Você está enganado, o asno é que come milho.

\subsection{Sentença com foco informativo no constituinte sujeito}

Sentença contexto:

K'bitx é kel k'ta kmê midju na bzôt kaza?

"Que animal é que come milho na vossa casa?"

Ôz é k’ta kmê midj

Ôz é k' ta kmê midj

Asno COP FOC HAB comer milho

É o asno que come milho 


\section{GRUPO 5}

\subsection{Sentença relativa}

Ôm k'ta pega na nxada deve dôd valor

$\begin{array}{lllllllll}\hat{\text { Omm }} & \mathbf{k}^{\prime} & \text { Ta } & \text { Pega } & \text { Na } & \text { Nxada } & \text { debê } & \text { Dôd } & \text { valor } \\ \text { Homem } & \text { PRO }_{\text {rel }} & \text { HAB } & \text { pegar } & \text { Em } & \text { Enxada } & \text { deve } & \text { Dar } & \text { valor }\end{array}$

Homem que trabalha com a enxada deve ser valorizado.

\subsection{Sentença com foco contrastivo no constituinte sujeito}

\section{Sentença contexto:}

Bo faló-m ma na Skemada mdjer é k'ta pega na nxada

"Você me disse quem em Queimadas as mulheres é que pegam na enxada"

(Naun) ôm é k’ta pega na nxada.

(Naun) ôm é $k$ ' ta pega na nxada

(Não) homem COP FOC HA pegar em enxada

Homem é que pega na enxada.

\subsection{Sentença com foco informativo no constituinte sujeito}

$\underline{\text { Sentença contexto: }}$

Na Skemada, Kin k'ta pega na nxada?

"Em Queimadas, quem pega na enxada?"

Na Skemada, é ôm k'ta pega na nxada

$\begin{array}{lllllllll}\text { Na } & \text { Skemada } & \mathbf{E}^{\prime} & \text { Ôm } & \mathbf{k}^{\prime} & \text { Ta } & \text { pega } & \text { na } & \text { Nxada } \\ \text { Em } & \text { Queimadas } & \text { COP } & \text { Homem } & \text { FOC } & \text { HAB } & \text { pegar } & \text { em } & \text { enxada }\end{array}$

Em Queimadas, é homem que pega na enxada.

\section{GRUPO 06}

\subsection{Sentença relativa}

Pai k' ta korriji fidj ta ivita problema

$\begin{array}{lllllll}\text { Pai } & k^{\prime} & \text { Ta } & \text { Korriji fidj } & \text { Ta } & \text { ivita problema }\end{array}$

Pai $\mathrm{PRO}_{\text {rel }} \mathrm{HAB}$ Corrigir filho HAB evitar problema

O pai que corrige o filho evita problemas.

\subsection{Sentença com foco contrastivo no constituinte sujeito}


$\underline{\text { Sentença Contexto: }}$

Es faló-m ma na Saninklau oj in dia fidj é k’ta korriji pai, é devera?

"Me falaram que em São Nicolau hoje em dia os filhos é que corrigem os pais, é verdade?"

Pai é k’ta korriji fidj

Pai é $\quad k^{\prime} \quad$ ta $\quad$ korriji $\quad$ Fidj

Pai COP FOC HAB corrigir Filho

O pai é que corrige o filho.

\subsection{Sentença com foco informativo no constituinte sujeito}

Sentença Contexto:

Na Saninklau kin k ta korriji fidj?

"Em São Nicolau, quem corrige of filho?"

É pai k'ta korriji fidj

é pai k' ta korriji fidj

COP pai FOC HAB corrigir filho

é o pai que corrige o filho.

\section{GRUPO 07}

\subsection{Sentença relativa}

Kmida k'ta na txon é d'gôt má katxor

$\begin{array}{lllllllll}\text { Kmida } & k^{\prime} & \text { Ta } & \text { na Txon é } & d^{\prime} & \text { gôt } & \text { Má katxor }\end{array}$ Comida $\mathrm{PRO}_{\text {rel }} \mathrm{HAB}$ txon Chão COP de gato ADT cachorro A comida que está no chão é dos gatos e cachorros.

\subsection{Sentença com foco contrastivo no constituinte sujeito}

Sentença contexto:

Kand bo jga, bo faló-m ma água ta na txon, ka dvera?

"Quando você chegou, você me disse que a água está no chão, não é verdade?

Naun, kmida é k'sta na txon

$\begin{array}{lllllll}\text { Naun } & \text { Kmida } & \mathbf{E} & \mathbf{k}^{\prime} & \text { Ta } & \text { na } & \text { txon } \\ \text { NEG } & \text { Comida } & \text { COP } & \text { FOC } & \text { HAB } & \text { em } & \text { chão }\end{array}$

Não, a comida é que está no chão. 
7.3. Sentença com foco informativo no constituinte sujeito

Sentença contexto:

Kzê k'sta ai na txon?

"O quê que está no chão?"

É kmida k' ta na txon

$\begin{array}{llllll}\text { É } & \text { Kmida } & k^{\prime} & \text { Ta } & \text { na } & \text { txon }\end{array}$

COP Comida FOC HAB em chão

É a comida que está no chão.

\section{GRUPO 08}

\subsection{Sentença relativa}

Gôt k'ta roba na panela ta fazê um psoa skua d'kabesa

Gôt k' $\quad$ Ta roba Na Panela ta Faze un psoa skua d' kabesa Gato $\mathrm{PRO}_{\text {rel }} \mathrm{HAB}$ roubar Em Panela HAB Fazer DET pessoa escapar de cabeça Gato que rouba na panela faz uma pessoa perder a cabeça.

8.2. Sentença com foco contrastivo no constituinte sujeito

Sentença contexto:

Na bzôt kaza, anton katxôr é k’ta roba panela, ka dvera?

"Na vossa casa, então cachorro é que rouba na panela, não é verdade?"

Naun, gôt é k’ta roba na panela.

$\begin{array}{lllllll}\text { Naun Gôt é } & k^{\prime} & \mathrm{Ta} & \text { roba } & \mathrm{Na} & \text { panela }\end{array}$

Não Gato $\mathrm{COP}$ FOC $\mathrm{HAB}$ roubar $\mathrm{Em}$ panela

Não, gato é que rouba na panela.

\subsection{Sentença com foco informativo no constituinte sujeito}

Sentença contexto:

Na bzôt kaza kal bitx é k’ta roba na panela?

"Na vossa casa, que animal é que rouba na panela?"

Na nos kaza, é gôt k’ta roba na panela. 


$\begin{array}{llllllllll}\text { Na } & \text { nos } & \text { kaza } & \text { é } & \text { Gôt } & \text { k' } & \text { ta } & \text { roba } & \text { na } & \text { panela } \\ \text { Em } & \text { nossa } & \text { Casa } & \text { COP } & \text { gato } & \text { FOC } & \text { HAB } & \text { roubar } & \text { em } & \text { panela }\end{array}$

Na nossa casa, é gato que rouba na panela.

\section{GRUPO 09}

\subsection{Sentença relativa}

Un tia k’N ka ta konxê dja ont na Saninklau

Un tia $k$ ' $N$ ka ta konxê jga ont na Saninklau

DET tia PRO $_{\text {rel }}$ 1SG.NOM NEG HAB conhecer chegar ontem em São Nicolau Uma tia que eu não conheço chegou ontem em São Nicolau.

\subsection{Sentença com foco contrastivo no constituinte sujeito}

Sentença contexto:

Es faló-m ma bo ten un tiu k’bo ka ta konxê, é dvera?

"Me disseram que você tem um tio que você não conhece, é verdade?"

(Naun), un tia é k’N ka ta konxê

(Naun) un Tia é $\mathrm{k}^{\prime} \quad \mathrm{N} \quad \mathrm{ka}$ ta konxê

(Não) DET tia COP FOC 1SG.NOM NEG HAB conhecer

(Não), uma tia é que eu não conheço.

\subsection{Sentença com foco informativo no constituinte sujeito}

Sentença contexto:

Kal k’é kel bo família k’bo faló-m ma bo ka ta konxê?

"Qual que é aquele parente que você me disse que não conhece?"

É un tia k'N ka ta konxê

$\begin{array}{llllllll}\mathbf{E}^{\prime} & \mathbf{u n} & \text { tia } & \mathbf{k}^{\prime} & \mathbf{N} & \mathbf{k} & \text { ta } & \text { konxê }\end{array}$

COP DET tia FOC 1SG.NOM NEG HAB conhecer

É uma tia que eu não conheço.

\section{GRUPO 10}

10.1. Sentença relativa

Un môss k'ben d'Brazil aont, purguntó-m pa bó

Un moss $k^{\prime}$ ben $d^{\prime}$ Brazil Aont purguntó $m$ pa bo 
DET moço PRO $_{\text {rel }}$ vir de Brasil Ontem perguntar 1SG.DAT por 2SG.DAT Um moço que veio do Brasil ontem, perguntou-me por você.

10.2. Sentença com foco contrastivo no constituinte sujeito

Sentença contexto:

Es faló-m ma un mnina ben d'Brazil aont.

"Me disseram que uma menina veio do Brasil ontem."

(Naun), un moss é k'ben d'Brazil aont

(Naun) un moss é $\quad k^{\prime} \quad$ Ben d' Brazil aont

(Não) DET moço COP FOC Vir Do Brasil ontem

(Não), um moço é que veio do Brasil ontem.

10.3. Sentença com foco informacional no constituinte sujeito

\section{Contexto:}

Kin k'ben d'Brazil aont?

"Quem que veio do Brasil ontem?"

É un moss k'ben d'Brazil aont

$\begin{array}{llllll}\mathbf{E} & \text { un moss } & k^{\prime} & \text { ben } & d^{\prime} & \text { Brazil aont }\end{array}$

COP DET moço FOC vir do Brasil ontem

Foi um moço que veio do Brasil ontem. 